
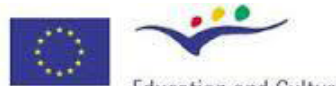

Erasmus Mundus

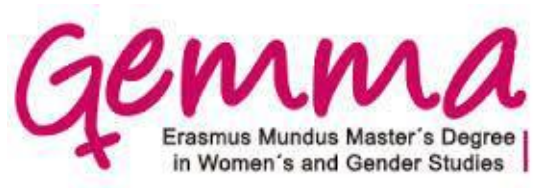

Erasmus Mundus Master's Degree in

Women's and Gender Studies

\title{
Mapping Love
}

Ethnography of migrant women squatters in

Florence, Italy

\author{
Claudia Morini
}

Main supervisor

Marta Zarzycka

Utrecht University

\section{Support Supervisor}

Soledad Vieitez Cerdeño

Universidad de Granada

\author{
Utrecht University, Faculty of Humanities \\ August 2016
}




\section{Gemma}

Erasmus Mundus Master's Degree in

Women's and Gender Studies

\section{Mapping Love}

Ethnography of migrant women squatters in

Florence, Italy

Claudia Morini

Main supervisor

Marta Zarzycka

Universiteit Utrecht

Support Supervisor

Soledad Vieitez Cerdeño

Universidad de Granada 


\begin{abstract}
Love is one of the most important experiences in women's lives. It has been deconstructed by feminism in its romantic and universal facets. Love still engenders damages as well as new kinds of fulfilment and support for women. This thesis claims the importance of love as a political tool, analysing its manifestations in the stories of a group of migrant women squatters in Florence, Italy. This ethnography identifies both old patterns of subjugation disguised as love that women suffer from their partners, as well as new patterns men's power in love takes within the migratory experience. However, this research shows also positive manifestations of love and emotions between empowered women who find the strength to free themselves from their partners' subjugation, and establish a women-only squat. This investigation therefore manages to demonstrate why love is important in connection to migration, a current fundamental geopolitical topic, and how the practice of squatting enables the women I interviewed to fight different layers of stereotypes targeting both migrant women and Muslim women. "Sisterhood", communal maternal practices and new forms of female multicultural cohabitation, despite the precarious and illegal aspects of living in a squat, emerge as the rich findings of my investigation.
\end{abstract}

\title{
Resumen
}

El amor es una de las experiencias más importantes en las vidas de las mujeres. El Feminismo lo ha deconstruido en sus facetas románticas y universales. Así, el amor engendra tanto perjuicios, como nuevas formas de plenitud y respaldo para las mujeres. Esta tesis aborda la importancia del amor como arma política, analizando sus manifestaciones en historias de un grupo de okupas mujeres (Florencia, Italia). Esta etnografía identifica viejos patrones de subordinación, disfrazados de amor, sufridos por las mujeres a cargo de sus parejas, así como nuevas muestras de poder masculino en el amor en contexto migratorio. Sin embargo, esta investigación desvela manifestaciones positivas del amor y emociones que empoderan a las mujeres, quienes encuentran fortaleza suficiente para liberarse de la opresión de sus parejas y establecerse como okupas, sólo mujeres. Por ello, esta investigación demuestra por qué el amor adquiere importancia en relación con la migración, un tema fundamental y actual de carácter geopolítico, y cómo la práctica okupa posibilita luchar contra diferentes estereotipos a las entrevistadas, tanto musulmanas como migrantes en general. Prácticas maternales comunitarias, "hermandades" y nuevas formas femeninas de cohabitación colectiva, aún con precariedad e ilegalidad en la ocupación, son hallazgos muy relevantes de mi investigación. 


\section{/ grazie}

Grazie a Nadia M., Suad, Khadija, Maria, Nadia A., Hanan per avermi permesso di ascoltare le loro storie. Grazie a Fatima, Nadia, Marwa, Mohammed e Mehdi per aver condiviso con me gelati e sorrisi. Grazie a tutta l'occupazione delle donne per avermi aperto la porta e fatta sentire a casa.

Thank you Marta, for your helpful supervision across the ocean.

Gracias Soledad, por ser tan apasionada en lo que haces y saberlo trasmitir con emoción y sonrisas a las Gemmas. Gracias por tus palabras y tus "cartas" de apoyo! Tu curso me fascinó y abrió a nuevos mundos...

Thank you Radhika, because you made my language beautiful. Our transnational "letters exchange" was an empowering feminist collaboration.

Grazie Margherita, per essere accorsa, con sensibilità da giovane donna psicologa, ad ascoltare la storia di Nadia A.

Gracias Lau, porque eres la mejor "esposa" que podía elegir. Somos el "best team ever". Utrecht no habría sido casa sin ti. Lista para conquistar el mundo cantando al lado de tu guitarra...

Gracias $\mathrm{mi}$ Meli, porque eres la que mejor sabe tranquilizarme y darme fuerza. La sabiduría del feminismo se refleja en ti. Te quiero mucho.

Grazie Julia, perchè ne abbiamo passate tante e anche se con la mente a Napoli e il corpo sempre in viaggio, siamo più unite che mai. I tuoi matrimoni Palestinese-italiano hanno reso il mio un anno di vagabondaggi felici.

Gracias Marja, porque eres mi ejemplo de nómada. Gracias por tu ayuda, y sobre todo porque te emocionaste con este proyecto, un día en la playa de Follonica. Contigo empezamos un "manifiesto eterotopico feminista al Spritz" para nuestro futuro Gemma. El futuro es ya...

Gracias Isa, porque la noche en L'Osteria del Sole es solo la última de muchas noches de locuras juntas que espero seguirán. Viva el vino tinto y queso con peras en el Albayzin.

Gracias Magui, por ser siempre una soñadora. Porque si esta tesis tiene que ver con mujeres migrantes lo debo también a tu increíble viaje.

Gracias Judith, por tu sonrisa constante hacia el mundo. Líder indiscutible de nómadas, nuestra newsletter feminista. Este sueño no existiría sin ti.

Grazie Dafne, per salvarmi dal panico dicendo: “Morini, tranquilla, ce la farai...come sempre!". Grazie per la tua irano-napoletaneità!

Grazie Paolo, perchè mi ha fatta sempre sentire "unica", ripetendomi che ero la sua scommessa vincente.

Tutte le volte piango, ma ora so che non è un segno di debolezza.

Grazie Giulia, Claudia la mia Omonima, Ali, Tai, Chiara, Milo e tutt* coloro che non cito ma che sanno di essere parti importanti della mia vita.

La sisterhood di questa tesi vive in tutt* noi!

La sisterhood de esta tesis vive en tod*s nosotr*s!

Infine, grazie alla mia mamma. Senza di lei la claudia non potrebbe certamente essere una femminista. 
Libero cor nel mio petto soggiorna. Non servo alcun, ne d'altri son che mia.

Moderata Fonte

Para mis Gemmas nómadas, la familia que he elegido.

A Giulio Regeni, ricordando Damasco. Chiediamo ancora giustizia e verità. 


\section{Table of Contents}

Introduction:

Welcome to "L'occupazione delle donne"

Chapter One: Love........................................................................................ 7

Introduction $\quad 7$

Focus and Scope of the Thesis 8

$\begin{array}{ll}\text { The Personal is theoretical } & 10\end{array}$

What they told us about love... 12

Love/Hub/Amore: Love across cultures 14

Capitalism (not the Beatles)

taught you that "love is all you need" 19

The hidden face of love in Islam 20

Love and Migration 21

The Personal is political:

Why love is a properly political tool 25

Chapter Two: Migrations..................................................................... 27

$\begin{array}{ll}\text { Introduction } & 27\end{array}$

$\begin{array}{ll}\text { Confini / Borders } & 28\end{array}$

nómadas: migrant women 31

The Italian context 34

Squats and migration 38

Chapter Three: hitchhiking within hotel Madison, following women's stories................................................................. 41

Introduction 41

La famiglia è sempre la famiglia:

The importance of tradition and the strength of patriarchal gender roles 44

- Nadia M. 45

- Arkiya 52

- Maria 55 
Self-love...and more gender equality?

- Suad 58

- Hanan 63

- Khadija 68

Violence $\quad 74$

- Nadia A. 75

$\begin{array}{ll}\text { Maternal Love } & 77\end{array}$

Leaving the squat,

rethinking travel within women's stories 84

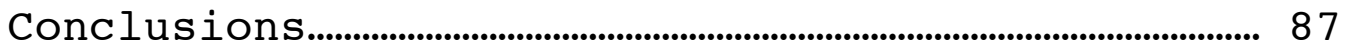

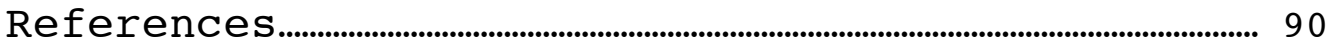

$\begin{array}{ll}\text { Websites } & 102\end{array}$

Appendices...................................................................................................................... 105

Appendix One: I'occupazione delle donne 105

Appendix Two: Whatsapp profile pictures 108

Appendix Three:

Young Italian Berbers' ideas of love 109 


\section{Welcome to \\ "l'occupazione delle donne" ${ }^{1}$}

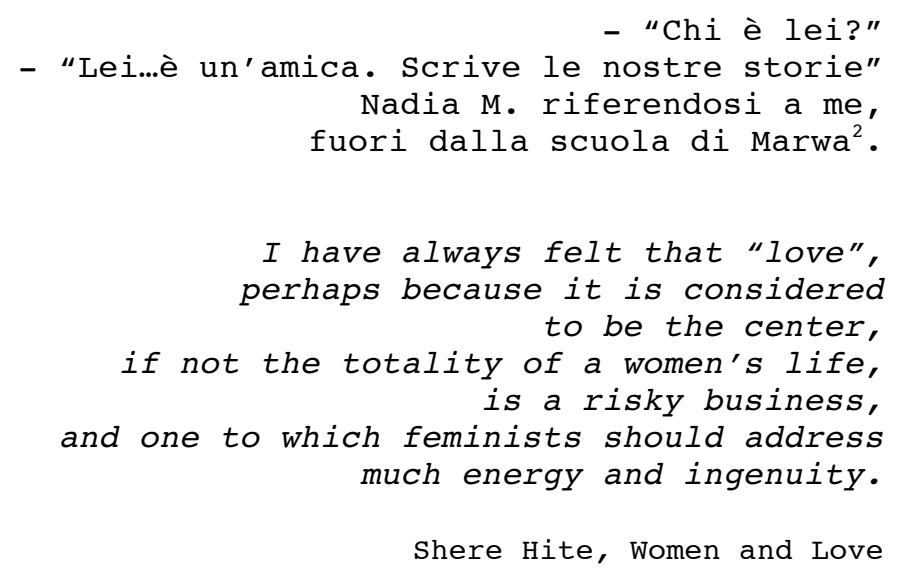

nómadas is a state of mind.

Love is a fundamental part of life. As feminists have shown, an analysis and engagement with its practice require continues efforts (hooks, 2002; Esteban \& Medina \& Távora, 2005). Because love-power (Jonasdottir, 2011) always takes new shapes, both in negative as well as in positive ways. Migration is one of the contexts where love transforms. It involves so many women and men in their different motivations or obligations to move, that is to be considered a contemporary feminist subject.

This thesis approaches the topic of love from an even more particular perspective. It analyses the affective relationships, both past and present, of a group of migrant women squatters in Florence, Italy. The only-women migrant squat where I was hosted in order to do my fieldwork is very special. Those women, particularly the Arab group $^{3}$, fight different layers of stereotypes that depict them as victims, defenceless and dependent. Their love stories and struggles - and how these intersect with their daily practices and political activism - will be analysed in depth in this thesis.

\footnotetext{
1 "The women's squat"

2 "Who is she?" "She...she's a friend. She writes our stories". Nadia M. referring to me out of Marwa's school. (My translation from Italian. Notes from the fieldwork diary).

${ }^{3}$ Moroccan, Tunisian, Romanian and Nigerian women compose the group of squatters.
} 
Considering the studied literature and the results of my interviews, I claim we need new tools and a different sensibility in order to understand affective relationships in migration and how these reconfigure, yet also emerge from, traditional schemes.

As a woman myself always on the move, I like to think of this research as one of my many travels, even if I unexpectedly decided to develop it in my hometown. I wanted to speak from a known context, a familiar one, where I could be aware of language, customs and rules, being therefore more accountable for what I was going to say (Haraway, 1988). Nonetheless, once I had entered in the women's house, the space was also an unfamiliar one, opening up to different worlds and habits, from Morocco to Romania...

After many years spent studying Arabic language and culture between Naples, Damascus, Rabat, Tunis and Granada, it was as if my background attracted Arab women as the most willing group among all the squatters to involve me in their stories. Moreover, Moroccan women were proud to discover that what motivated me to study Arabic was not prejudice against Islam or Arabic countries, but rather fascination.

Although those were not the first Arab women with whom I have spent time in my life, it was the first time that I gained insight to the world of squat activism. I am not, in fact, an activist myself. Not coming from an activist perspective, what initially drew me to this group was women's co-housing rather than the political practice of squatting. I have witnessed women's loneliness in my life and I fear it. " $L$ 'occupazione delle donne" seemed like a women co-housing experiment with the added value of reclaiming housing rights in times of wide-spread precariousness.

Once immersed in the squat, I realized that my underlying impulse that led me to feminism was the attempt to make sense of women's subjugation in love. Romantic love appears to me as the last battlefield on which women surrender to patriarchy. Needless to say, the loneliness to which I allude above was a consequence of romantic love...

Positioning myself in the field was a complex issue (Abu-Lughod, 1986; 2000; Alcázar Campos, 2011; 2014; Best, 2003; DeVault and Gross, 2007; Gregorio Gil, 2000; Trejo Velasco, 2015; Stout, 2014). I was both an insider - as an Italian in Italy and as an Arabic speaker among Arab women - as well as an outsider - as a researcher in a squat that seemed like a "foreign" country inside Italy. Moreover, recognizing my 
privilege - mostly in terms of class, ethnicity (Best, 2003), citizenship, age ${ }^{4}$ and, importantly, role (Vives, 2012) - was not sufficient in order to always make me feel comfortable in the field (Alcázar Campos, 2011; Trejo Velasco, 2015). As it often occurs in feminist ethnography, I sometimes felt paralysed regarding my right to tell other women's stories. I doubted whether my work would be able to contribute anything concrete to their lives (Alcázar Campos, 2011; Best, 2003; DeVault and Gross, 2007; Preissle, 2006). I hope now that the relation we built - made especially of many informal moments ${ }^{5}$ - made them feel important. They were astonished to learn that my interest was not in the squatting movement, but rather their personal lives in all its facets. I like to think that I contributed to sow the "feminist seed" in Marwa, Fatima and Nadia's growth, in the hope this will help them to feel pride in being born a woman.

Before becoming a "trusted" woman in the eyes of my subjects, it was difficult to get in touch with them ${ }^{6}$. Often, my calls and the informal commitments we had made were ignored. The squat, not surprisingly, was an informal place. When I eventually succeeded in becoming part of the group at the end of my fieldwork, it was hard to position myself primarily as a researcher rather than a friend (Kirsch, 2005; Viven, 2012). Now, I am faced with the sensation of "abandoning" them, especially the daughters. ${ }^{7}$

\footnotetext{
${ }^{4}$ Age, in my particular case, contributed to build a "hierarchy" between some of the women and me, given that we are almost peers but we do not share he same experiences as women: I am not a mother. Best (2003) talks of her being an "outsider" researcher in the context of race.

${ }^{5}$ These are examples of the many things I did as a "friend" during more informal moments: bring food, accompany them to the lawyer, accompany Suad and her four-months old child Mehdi to the doctor, bring the children to have ice-creams outside or to the park, help Nadia M. by night in Florence streets to carry heavy packeges to send to Morocco through a moroccan truck driver, accompany Nadia M. to Marwa's school.

${ }^{6}$ Through Facebook, I was able to contact an activist of the movement who then took me to the squat. After having accepted the idea of my research, some of the women gave me their phone number, and WhatsApp was our privileged medium of communication.

${ }^{7}$ At the time of writing this thesis I continue keeping in touch with some of them, especially with the daughters, who look and ask for me.
} 


\section{Methodology}

The methods of my feminist ethnography (Abu-Lughod, 1986; 1990; Alcázar Campos, 2011; Maher, 1989; Mernissi, 1988; Salih, 2003; Stacey, 1988; Stout, 2014; Trejo Velasco, 2015) ranged from semi-structured interviews (DeVault and Gross, 2007; Best, 2003;) to what D'Odorico (2014) refers to as the "biographical approach". In migration studies, the latter allows me to make sense of the subjects' stories without forgetting a structural perspective (Salih, 2003). I further tried to let the subjects speak with their own words ${ }^{8}$ - since, as Medina Dómenech (2013) says, their knowledge about love and life has the relevance "expert" discourses lack (Mohanty, 2003; Spivak, 1988). The "hybrid" mix of languages" that I encountered in the field, and that we created together to communicate, reveals migration prominence in contemporary Italy.

I conducted recorded as well as written interviews, more than participant observation during two weeks of fieldwork. I started to get in touch with the women in December 2015, and I visited them more than once before starting the fieldwork. Out of ten women and five children living in the squat, I interviewed five adults and two daughters. During the fieldwork, I tried not to arbitrate between those who possessed "genuine" sentiments and who did not (Stout, 2014). In addition, I recognized certain prejudices that I had interiorized against Islam (D'Odorico, 2014), despite many passionate years involved in the topic. The practical help I provided the women ${ }^{10}$ partially compensated for my privileged position.

Lastly, I want to stress two aspects involved in doing research with Arab women. First, as Abu-Lughod (2000) noted, the difficulty to write about an Arab community for a Western audience, that is generally "antipathetic" to their world. Second, following a strict interview guide was challenging: my experience of engaging with "Arab" women showed that the initial distrust often transforms into a limitless flow of stories. I quickly became a friend who spoke to them about love and got emotionally involved. The denial of scientific "objectivity" and the researcher's detachment in feminist ethnography (Moore, 1988; Vives, 2012; Kirsch, 2005; Hesse-

\footnotetext{
${ }^{8}$ These had inevitably been translated to English by myself. I am conscious, therefore, that as for every translation, despite its best intentions, this represents my personal interpretation.

${ }^{9}$ Mostly Italian and some Moroccan and MSA (Modern Standard Arabic) words.

${ }^{10}$ See note 3 .
} 
Biber, 2011), gains currency in the Arabic context where personal relationships are crucial to any form of investigation.

\section{L'occupazione delle donne}

"L'occupazione delle donne" of Florence is exceptional. The women who collectively occupy the space resist the invisibility that the Italian state imposes on migrants. This project, however, focuses on their resistance to love-power and how they transform it, by deconstructing cultural manifestations of patriarchy.

This appears to be the only squat reserved solely for women in Italy ${ }^{12}$. Currently, ten migrant women and their children live in the squat. Some of them have lived in the squat since its inception, while others joined more recently. Five of them are from Morocco, one from Tunisia, two from Nigeria and one from Romania ${ }^{13}$. Their ages range from thirty to sixty-four years. At the time of my fieldwork there were five young children living there ${ }^{14}$. Each woman has the "right" to her own bedroom and her own kitchen in the building that was once a dingy hotel - Hotel Madison - in the suburbs of the city. Despite theoretically being equal as squatters, some have better furnished rooms situated closer to the only two toilets. In the only empty room, they meet twice a month with women

\footnotetext{
${ }^{11}$ This way of calling the squat does not have any reference to their being migrants.

${ }^{12}$ It is located in Via Bardazzi 4 and is the third experiment after two shorter occupations. The first experiment started on October the $25^{\text {th }}$ of 2013 in Via Crimea 39, Florence. One month later, after being evicted, the group of women squatted another empty apartment in Via Pier Capponi 51. They were then evicted again on June 2014 with a huge un-useful employment of police. More information could be read at this website: http://www.inventati.org/cortocircuito/2014/06/05/sgomberata-loccupazione-di-via-piercapponi-51/ (Last access on July 31th 2016). The original group of squatters was a mix of migrant and Italian women with their children. The current building has been empty since 1999 . Information about it can be read at the following website: http://www.ilfattoquotidiano.it/2014/07/02/servizi-sociali-caseinadeguate-e-un-gruppo-di-donne-occupa-un-hotel/1047296/ (Last access on July 31th 2016). A similar squatted building occupied by two hundreds Moroccans, mostly women and their children, existed in Bologna in the Nineties (Zontini, 2010). It represents an important precedent since the municipality of the city worked towards finding a solution and the created in 1993 the first CPA (center for first arrival). Given the current crisis, similar experiments of only-women squats are underway in other European countries, even if they started with a clearer feminist consciousness than this Florentine case. In Greece, women joined together creating "women houses" to help each other during the crisis. For information see: https://femeninorural.wordpress.com/2016/01/16/crecen-las-casas-de-mujeres-autogestionadas-en-grecianinguna-sola-durante-la-crisis/ (Last access on July 31th 2016). In East London a group of young women recently occupied a house with the intent to create a safe space free of violence. More info here: http://www.huckmagazine.com/perspectives/activism-2/24-hours-sisters-uncut/ (Last access on July 31th 2016).

${ }^{13}$ I did not hade the chance to interview nor meet all of them. Anyways, I included the interviews to a Moroccan woman who was being hosted in the squat at the time of my fieldwork, Hanan.

${ }^{14}$ The children living in the squat are all of Moroccan mothers except for a Nigerian boy. The interviews presented in Chapter Three will clarify how some of the children are currently living in their countries of provenience.
} 
activists from the "Movimento di Lotta per la Casa"15. They have rules concerning the cleaning of social spaces inside the house. The entire "original" group has pending penal charges because of their squatting practices ${ }^{16}$.

The experiment began when the original group of women, who had all experienced gender violence, precariousness and homelessness, met through the Movement ${ }^{17}$. Given the high number of single women seeking help, the Movement initiated the first onlywomen squat. Lia, an activist, told me that the idea surged from the stereotyping of Muslim women who would refuse to live in a squat with men. A feminist experiment was thus born unintentionally. They even established a women legal help desk inside the squat for a while, which was run by legal volunteers ${ }^{18}$.

As for other squatters, women must participate actively in the Movement's demonstrations and struggles. The Arab women appear to be the most engaged in activism $^{19}$. As Salih (2001) argues, transnational migrants are more politically active in the emigration context ${ }^{20}$.

\section{A map with No borders ${ }^{21}$}

The coordinates of this thesis/map are as follows: The first chapter claims for the political relevance of love, especially in the context of migration. The second chapter focuses on women's migration, which though fundamental has been sidelined in migration studies. The third chapter presents the ethnography. I invite the reader to accompany me on this particular hitchhike ${ }^{22}$ following women's stories within the squat. I am convinced women's emotionality can change the world.

\footnotetext{
15 "Movimento di Lotta per la Casa" is Florence squatting movement. Lia and Arianna are the activists in charge of that particular squat, continuing so doing the female line.

${ }^{16}$ They are being helped in the legal process by a group of volunteer lawyers. I once had the chance to participate in one of their meetings at the legal office and it was interesting to notice Moroccan women's better trust in the woman lawyer's suggestion and manners than to the man's.

${ }^{17}$ The Arab group called the movement for squatting in a funny way, placing before the Arabic article: "Al-Movimento".

${ }^{18}$ See Appendix One.

${ }^{19}$ Some of them even moved to other cities in order to participate in national demonstrations.

${ }^{20}$ On the contrary Morokvasic's argues that the oppression migrants experience hardly ever leads to collective action (1984).

${ }^{21}$ I refer here to No Borders, a movement and a migrant permanent camp located in Ventimiglia (Italy) at the borders with France.

${ }^{22}$ The metaphor of hitchhiking came to my mind when an Argentinian traveller arrived to my Dutch home, "un poco pedaleando y otro poco a dedo" (a bit cycling and a bit hitchhiking). Feminism taught me the importance of memory, so I like to include and remember all the people that have been part of my nine-month hitchhike.
} 


\title{
Chapter 1: Love
}

\author{
"Il miglior modo di ricordare tua nonna", \\ mi aveva detto in punto di morte,

\section{Introduction}

Although love remains an unexplored country, it is nevertheless a sovereign one that rules over people's lives, choices, and beliefs. It appears to be the emotion par excellence; one that cannot be avoided if the world is to follow its course. All too often, we hear the saying, "love moves the world." Yet, love is so unexplored that it continues to be enveloped by gender stereotypes, social beliefs, and contrasting practices that are implicit, unquestioned, and, therefore, unexplained. As Berlant cogently argues, intimacy "involves relations that largely proceed by way of what goes without saying" (Berlant, 2011:686). The paucity of words and tools for analyzing love has historically constituted a hindrance for both academics and activists. Although love is considered as one of the most important life experiences (El-Saadawi, 1991), it is a cultural

\footnotetext{
23 "The best way to remember your grandmother", she told me from the death-bed "is to hand down my favourite story of Shahrazad, that about the woman with the plumage dress". I learnt by heart that story. It teaches that a woman should always live like a nomad, always attentive, always ready to migrate even when she is loved. Because love could absorb her totally, and become her prison...(My translation from Italian).

24 "Because there is no perfection in love, but a country where the lover can change her currency" (My translation from Spanish).
} 
construction that is sustained by power. ${ }^{25}$ Even in its grandest expression, the couple's relationship cannot be deemed totally equal and balanced.

Feminism's efforts to reveal the patriarchal grounding of love, as conceptualized and lived by both women and men, are historically unprecedented. Western feminists (e.g., hooks, 2002; Esteban Galarza, 2008, 2011; Esteban Galarza, Medina-Domenéch, \& Távora Rivero, 2005; Jónasdóttir, 2011; Magallón Portolés, 1991; 1997; Maher, 1989; Medina-Doménech, 2012, 2013) as well as Arab feminists (El-Saadawi, 1991; Mernissi, 1975, 1988) have confronted this task. In doing so, their intention has been to demolish women's exploitation that is the underlying basis of love (El-Saadawi, $1991) .^{26}$

Queer theory (Berlant; 2011; Stout, 2014) has uncovered a new way to capture the "multiplicity of beats" connected to emotions and "affective facts" (Berlant, 2011:686). Feminism ${ }^{27}$ and queer theory have contributed to unearthing what Gordon (2008) has evocatively conceptualized as "ghostly matter;" namely feelings experienced when love and emotions are in the air.

\section{Focus and scope of the thesis}

This thesis aims to explore past and present love in the lives of migrant women squatters in Italy. In doing so, it applies a postcolonial lens to envision these lives within a transnational context (Appadurai, 1996; Mohanty, 2003; Bhabha, 1994; Ponzanesi, 2014; Said, 1994; Spivak, 1988; Kabesh, 2013a, 2013b). The past is explored through the women's own narratives, while simultaneously analyzing its social, cultural, and religious foundations. ${ }^{28}$ An exploration of love in the past reveals its normative face; that of heterosexual romance. In contrast, an exploration of the present attends to everyday interactions among women, and to the roles that other women-friends and relatives - as well as children play in stories of their past. Here, love reveals its most hidden face; that of women's solidarity, "sisterhood" (hooks, 1986), and maternal love.

\footnotetext{
${ }^{25}$ Jónasdóttir (2011) has conjoined Marxist theories of power with love, coining the term "love power".

${ }^{26}$ The theories of black feminists and others within the postcolonial feminist movement provide a fundamental starting point for deepening understanding of contexts other than the one under study that mostly centers on Arab women in Italy.

${ }^{27}$ Betty Firedan is one of the most famous exponents of second-wave feminism. Her book, "The Feminine Mystique" (1963) was a precursor to a body of literature that engages with the inexplicable feelings of sadness and depression experienced by women trapped within the North-American capitalist dream of being a good wife and mother.

${ }^{28}$ See Chapter Three for the ethnographic findings and analysis.
} 
This chapter presents a historical and theoretical introduction of love. However, I chose to focus on theorizations of heterosexuality (psychoanalytical, biological, religious, socio-cultural, and capitalist) for two reasons. First, heteronormative love is one of the fundamental pillars of an enduring patriarchal order that continues to regulate many different dimensions of people's lives. Second, heterosexuality was the kind of coupled love that the women who were the subjects of this thesis had experienced. ${ }^{29}$

Romantic (heterosexual) love in the Western "secularized" world (Bracke, 2008; Braidotti, 2008; Butler, 2009; Gole, 2010; Scott, 2009) has even been exalted as a substitute for religion (Esteban Galarza, 2011:41). ${ }^{30}$ In a globalized and uncertain world (Treacher Kabesh, 2013), love sometimes appears to offer the only avenue for overcoming difficulties. This romantic passion finds in jealousy its "measure" (Esteban Galarza, 2011:50).

Retracing the history of love helps to shed light on the painful unfairness of romantic love for women and furthers understanding of all the "other" powerful forms that love could take. I intend to politically label as "love" (Mai and King, 2011) especially women's solidarity and maternal love, which I could observe in the field without resorting to any pre-constituted knowledge.

Love's clichés - prince charming, the other half, love at first sight - are part of a linguistic-cultural construction that is based on the exploitation of women's affective capacities. Nonetheless, we are now witnessing how love literally "moves the world." The movements to Italy of most of the women whom I met and interviewed, and with whom I spent many informal moments, were propelled by love. At least, this explicit propulsion marked the beginning of their stories. Perhaps their process of migration was built upon a wider range of silent desires that intertwined with their social obligations as wives and mothers (Boehm, 2011). Nonetheless, they explicitly followed the course of love. Whether viewed as an excuse, both cultural as well as juridical (as in the case of family reunifications), as an obligation, or as the "real" motivation, love does in fact "move" many women to engage in one of the greatest contemporary challenges: that of

\footnotetext{
${ }^{29}$ We must also bear in mind that apart from contending with the issue of social acceptance, the practice of homosexuality is considered illegal in many Arabic countries. More information on this can be found at the following websites: https:/www.washingtonpost.com/news/worldviews/wp/2016/06/13/here-arethe-10-countries-where-homosexuality-may-be-punished-by-death-2/ (Last access on July 31th 2016) Developing insights into same-sex and queer love would have required further theoretical tools and space beyond the scope of this thesis. I am aware that same-sex love between partners does not guarantee the avoidance of a power imbalance (Esteban Galarza, 2008).

${ }^{30}$ My translation of the Spanish text.
} 
migration (Roca i Girona Bodoque Puerta \& Monserrat Soronellas, 2012). Migration, especially when associated with the squat, to borrow Berlant's (2012) concept of "zoning," constitutes an innovative "site" for applying these theories.

Starting from the acknowledgement that love is cultural (Berlant, 2011; Ahmed, 2014; Esteban Galarza, 2008, 2011), which derives primarily from the social anthropological approach adopted here (see Lutz and Abu-Lughod, 1990), I will explore some cultural differences between the Arab-Muslim and Western-Christian worlds ${ }^{31}$.

The chapter ends with a call to consider the political importance of love (Ahmed, 2014; Berlant, 2000, 2011, 2012; Esteban Galarza, 2008, 2011; hooks, 2002; Jaggar, 1996; Jónasdóttir, 2011) as a tool for understanding and changing current women's conditions.

Applying this framework, I endorse the conviction of Berlant $(2011,2012)$ and hooks (2002) that a new theory of love is needed. Such a theory would begin by considering love as a utilitarian patriarchal project, as well as an incoherent, contradictory, and still inexplicable attachment.

\section{The personal is theoretical ${ }^{32}$}

“There is nothing more alienating than having one's pleasures disputed by someone with a theory" (Berlant, 2012:5). I do not pretend to have a theory that manages to provide a clear explanation of what love is, let alone distinguishing "genuine" and true ways of living it (Stout, 2014). I will, therefore, limit myself to briefly presenting what has been said about love, and what, in my opinion, still needs to be said. I am convinced that what is missing from a theory can only be provided by personal stories and the reality of everyday life. In this regard, I find Medina Doménech's statement that: "love is a history of which one could speak through other histories" $(2013: 20)^{33}$ particularly intriguing. Medina Doménech's approach can be considered to be rooted in Gayatri Chakravorty Spivak's (1988) articulation of the dignity and significance of the

\footnotetext{
${ }^{31}$ Such significant differences are exemplified in the linguistic discrepancy that wants love to be and the prevalent Arabic word " $H u b$ " that is often uttered by lovers as well as friends. This example offers a preliminary hint regarding cultural differences in relation to the topic of love and how this is lived, especially by the subjects of this thesis.

32 In light of the claim of Second Wave feminists that "the personal is political," we can consequently affirm the theoretical relevance of our personal lives. I am especially thankful to my Gemma professors, Carmen Gregorio and Ana Alcazar, for introducing me to this specific formulation.

${ }^{33}$ My translation of the Spanish text.
} 
postcolonial "subaltern" for changing the world. The particular subjects of my thesis can be regarded as "subalterns", applying two definitional axes; one of women and one of genuinely postcolonial subjects.

Mari Luz Esteban (2008) calls the cultural ideology that informs and binds together laws, practices, and socialization processes, developed in the West from the period of Modernity onwards, as "Love thought" (Pensamiento amoroso). As Esteban (2011:47) observes, in this hegemonic emotion-based model, "love is emphasized in front of everything else, not only other emotions, but also other human facets (solidarity, justice, freedom...)". She further argues that "love thought" is at the basis of an unequal social order, not only in terms of gender, but also in terms of class, ethnicity, and sexuality (Esteban, 2011). The heterosexual nature of this order implies a conception of masculine and feminine based on an "absolute dichotomist and complementary relationship" (2011:47). ${ }^{34}$ The consequent "specialization" in emotions assigned to women is the foundation of their subordination (Abu-Lughod, 1986). Esteban develops her thesis adopting Monique Wittig's idea of "the straight mind" 35 which considers heterosexuality as a "total social fact" (2011). Esteban consequently states:

The ideal-auto-assumed and hetero-imposed-for women is, in Adrienne Rich's words, "Love addiction", that is to say love through sacrifice as a redemptory form. This female "excess of love" is appropriated by men in an environment that fosters and approves them socially, leading to a deficit of equality that leaves us in a situation of inferiority. $(2011: 49)^{36}$

I believe that women's "excess of love" takes many forms, as in the case of love for friends (hooks, 2002). It is not a question of intensity, but one of consciousness. Because this kind of love energy has often been denigrated as being degenerate, it has consistently been deemed less worthy than romantic love, leading women to experience feelings of guilt (at least those who follow the Western paradigm). We could describe this love as "emotional labor," applying the term coined by the sociologist Arlie Russell

\footnotetext{
${ }^{34}$ My translation of the Spanish text.

${ }^{35}$ Monique Wittig (1992), The straight mind.

${ }^{36}$ My translation of the Spanish text.
} 
Hochschild ${ }^{37}$ that illuminates the "economic" aspects of women's daily work done "for love.” Returning to love energy, Esteban (2011:65) notes that:

Romantic society brings about tension (incompatibility) between different kinds of love that are to be considered, from another perspective, fundamental. ${ }^{38}$

While acknowledging love's importance, and its intrinsic polyvalence, we must be aware of how contemporary Western "certainties" have been weighted and filtered using a variety of what are generally considered "expert knowledges", shaping and limiting our comprehension (Medina Doménech, 2013:19).

\section{What they told us about love...}

The history of narrations and speculations about love, corroborated by "scientific" proofs, is to be found primarily in psychoanalysis and biology. Psychoanalysis, exemplified in the works of its most famous exponent, Sigmund Freud, at the beginning of 1900, aimed to penetrate the abstract and deep truth enveloping sentiments. Freud investigated sexuality and desire - and subsequently love as their concretization - as the only "true" sites for locating a person's identity (Berlant, 2012). This still constitutes a dogma, both in contemporary "affective neurosciences" (Medina Doménech 2013) as well as in popular culture, when it comes to defining people's identities.

Freud's psychoanalysis focused on desire and sexuality, emphasizing the particular importance of an individual's past and his or her relationships with both parents in the development of a certain kind of masculine or feminine personality. Psychoanalysis is aimed at navigating an individual's deep unconscious to explain and connect his or her personality with different kinds of childhood traumas (castration for boys and the experience of lacking a penis for girls).

Feminists have pointed out that Freud's theorization of the female personality appears to be merely a "bad copy" of that of the male. Subsequently, there have been

\footnotetext{
${ }^{37}$ See Russell Hochschild, The managed heart: commercialization of human feeling. (Berkeley: University of California Press, 1983).

${ }^{38}$ My translation of the Spanish text.
} 
attempts to positively re-interpret Freud's work, and the role of sexuality, from the perspective of feminism ${ }^{39}$.

The biological scientific approach places sharp emphasis on the mind/body dichotomy, essentializing differences between women and men in many aspects, and consequently, and importantly, in relation to love. Along with psychoanalysis, this approach has reinforced the entrenched patriarchal nature/culture dualism that situates women on the side of the natural world, associating them more with sensibility and less with intellect. This "natural" explanation posits that they are more subject to sensations and to the irrationality of emotions than men, who are able to control their instincts thanks to the strength of their "reason". This view of the intangibility of love, as an uncontrollable emotion that propels people to lose their rational functions still prevails when discussing this sentiment, at least in the West (Ahmed, 2014; Esteban Galarza, 2008). Women are considered as being more prone to romantic fantasies and compromise (Fisher, 1999) ${ }^{40}$, therefore having an un-ambivalent faith in the love plot (Berlant, 2011). This theorization has not only contributed to a perspective that emphasizes differences between the sexes and male supremacy that is difficult to dislodge, but also imbues such ideas with universality (Medina Doménech, 2013; Esteban Galarza, 2008).

All of the aforementioned knowledge fields that are strong of their compromise with the objectivity of "science," have reinforced the perception of the existence of sexual differences, especially concerning affect, between men and women. This position, therefore, serves to justify heterosexual marriage as the only possible structure; one that finds a basis first in the complementarity and then the inequality of the coupled partners (Medina Doménech 2013). Consequently, the construction of "woman" as a static unit, provided from birth with certain fixed "feminine" characteristics, is biologically rooted. Exclusively heterosexual marriage has, therefore, been viewed as a "biological destiny" (Medina Doménech 2013) for women, and their ways of dealing with it - and the sentiments involved - have also been decided a priori. Marriage was consequently buttressed by a variety of legislations. In most cases, these have had a

\footnotetext{
${ }^{39}$ Nancy Chodorow has emphasized that women's identification with their mothers makes them less violent rather than weaker, as Freud believed (Berlant 2012). For Berlant (2012), the only importance of the psychoanalytic approach for understanding desire lies in its stress on fantasy as the proper site of navigation within the unconscious. As Berlant (2012:6) observes, "without fantasy there will be no attachment and no love."

${ }^{40}$ Fisher (1999) stressed the role of sexual hormones in creating sexual desire, and the consequent differences between men and women.
} 
negative impact on women, regulating their obligatory duties as good wives, and at other times imposing ambivalent rules in women's lives as in the case of divorce that undoubtedly represented an achievement, but also caused emotional exhaustion. ${ }^{41}$

Religion evidently has also played a fundamental role within the marriage paradigm, placing women in a weak and passive position. The tradition and symbolism of the Virgin Mary — devoted and remembered solely as a mother and wife - serves as a model of how a good woman should behave within the Judeo-Christian tradition. It has been stressed, however, that in contemporary Western societies, affected by a crisis of religiosity, ${ }^{42}$ the belief in love as providing the way of reaching transcendence and happiness is deemed as a new form of religiosity (Esteban Galarza, 2011). This new belief, even if it is not imbued with tradition, would nevertheless safeguard the centrality of love in people's lives, and support its irrationality in our contemporary Western world.

\section{Love / Hub / Amore:}

\section{Love across cultures}

The socio-cultural approach to examining emotions (Ahmed, 2014; Berlant, 2011; Esteban Galarza, 2008; 2011; Jaggar, 1996; Lutz and Abu-Lughod, 1990) ultimately succeeded in debunking all of the aforementioned essentializing theories. It thereby also succeeded in contextualizing love.

Scholars such as Michelle Rosaldo underlined the "fragility of the cultural categories concerning emotions" (Esteban Galarza, 2011), while others, such as Foucault conducted a historical investigation of love, aimed at tracing its past (Esteban Galarza, 2011). Indeed, the most important aspect that requires examination in the current study is the relevance of culture and society when it comes to emotions, and the multitude of different media that a culture possesses for conveying them such as language and myths.

\footnotetext{
${ }^{41}$ Some of the interviews mentioned in Chapter Three clearly bring out the duties and disadvantages of women within marriage.

42 This is especially true in Southern European countries such as Italy, where the Roman Church is headquartered, and where the fieldwork for this thesis was conducted. This phenomenon provides an interesting and contrasting comparison to that of the widespread return to religion within migrant communities.
} 
As observed by Medina Doménech, love is both a "structuring" and an already "structured" emotion (2005:2). Arguing along the same lines, Sara Ahmed discusses emotions in terms of "effects" rather than "origins" (2014:192), thereby acknowledging the importance of culture as a cause of emotion.

However, from the perspective of anthropology, and especially feminist anthropology (Abu-Lughod, 1986; Maher, 1989; Moore, 1988; Salih, 2003; Stout, 2014), it is now accepted that cultures are not fixed and unchangeable clusters. Instead, they display a wide range of internal heterogeneity and are subject to different influences such as historical changes and globalization (Appadurai, 1996; Svazek and Skrbis, 2007) and constant encounters and merging with other cultures. This is undoubtedly the most important aspect that is highlighted by research conducted in a transnational context. Because culture is not a fixed entity, neither are women's (and men's) identities, as they are constantly negotiating among themselves and shaping their own subjectivity in encounters with the "other." ${ }^{43}$ Their wills and motivations are, therefore, also eclectic (Roca I Girona, Soronellas Masdeu, Bodoque Puerta, 2012).

During encounters with the investigator, language, as the privileged medium through which culture and desires are conveyed, inevitably constrains women's possibilities of expressing themselves. Moreover, on the investigator's part ${ }^{44}$, pigeonholing the motivations underlying their migratory experiences, as is now common practice within migratory studies (e.g., differentiating between economic and family motivations) would not be respectful of the plurality of their identities.

Having established the importance of culture in this chapter's analysis of love, I will present some of the main aspects to be considered. First, romantic love could be considered as a myth, given its constructed narrative support of which the investigator must be aware (Medina Doménech 2013:20). In the case of anthropological inquiries of the kind that I am pursuing here, it is important to emphasize that the consideration of love as a myth varies cross-culturally and is differently lived and interpreted. Jaggar (1996:151) has even ventured to claim that "in some cultures, romantic love does not exist at all."

Moreover, the encounter between two or more cultures - not just of bodies but also of identities that are increasingly "nomadic" as a result of globalization ${ }^{45}$ (Salih,

\footnotetext{
${ }^{43}$ The theories of Rosi Braidotti and Judith Butler are especially important in this regard.

${ }^{44}$ This will become clearer in successive chapters on migration and ethnography.

45 The reference here is to Braidotti's theorization of "nomadic subjects."
} 
2003) - influences a "new" myth about love, the cultural boundaries of which have become blurred, causing its nature to become "mixed." In such a context, one must be aware of the lack of "paradigms" available to the investigator to be able to somehow compare women's stories and their "expected" ways of dealing with their lives and actual practices. The most apt example is represented by women's roles within marriage in a transnational context.

However, returning to the view of love as a myth, Berlant states:

The difficulty to determine love's authenticity has generated a repository of signs, stories, and products dedicated to verifying that the "real thing" exists both among people and in other relations - for example, between people and their nations, their Gods, their objects, or their pets. (2012:7)

The ancient myths about love that represent what Medina Doménech has described as a "cultural ideology" $(2013: 17)^{46}$ are conjoined with more contemporary and "charming" messages that instruct the players how they must act within love's plot -a plot based on the exploitation of women's socialization as primarily emotional beings. In the context of my investigation of Arab women, soap operas operate as popular repositories of signs according to which female subjects act out love's plot ${ }^{47}$. As Berlant states, "modern women's fiction, in particular, seeks to create subjects who identify with love's capacity to overcome the troubles of everyday life" (2012:98). Therefore, this medium channels new romantic myths and social stories, that is to say, it represents a contemporary ideology par excellence. With soap operas reproducing the cultural status quo they further embed the female subject in capitalist dynamics. I will elaborate the connection between capitalism and romantic love in the next section.

\footnotetext{
${ }^{46}$ My translation of the Spanish text.

${ }^{47}$ Sscholars have investigated soap operas as an interesting medium for the examination of culture (Pepicelli, 2014). Soap operas in the Arab world serve to culturally - and to some extent linguisticallyhomogenize and "globalize" the huge Arab Muslim world. Having enjoyed decades of supremacy, the Egyptian "musalsalat," are apparently being replaced, according to my participants, by a more "modern" and up-to-date Turkish competitor. Apart from offering the public predetermined models of women's and men's behaviors, they somehow standardize those models to fit across a wide range of audiences that are culturally, linguistically, and geographically diverse. It would be of considerable interest for feminism to update the existing literature on the topic, paying attention to the emergence of Turkish soap operas in the context of Turkey's geo-political power and Erdogan's politics of both re-islamization and rampant neoliberalism.
} 
Language is the essential medium through which culture and this strict ideology of love are conveyed ${ }^{48}$. For Foucault, "discourses are practices that systematically form the objects of which they speak" (1972:49 cited in Abu-Lughod 1990:9). Following the same approach, Abu-Lughod states:

Taking texts and talks and all sorts of other social practices as productive of experience and constitutive of the realities in which we live and the truths with which we work, this approach also considers how power might produce discourses as well. $(1990: 10)$

Because language is fundamentally social, and the socio-cultural approach to love is the one that interests me here, language's ability to serve as a medium through which emotions, as social facts, can also be found, interests me. As Abu-Lughod states, despite the still widespread association of emotion as "the aspect of human experience least subject to control" (1990:1), it is nonetheless important and feasible to subject emotions to a sociocultural analysis. A conception of love as discourse evidently requires a consideration of all the forms through which this discourse is manifested. These include words but also their absence-as silence is itself a form of contextual discourse (Boehm, 2011) — as well as facial expressions, gestures, and postures, given individuals' cultural embodied experience of emotions (Ahmed, 2014; Lutz and Abu-Lughod, 1990). I will concentrate more on the embodied characteristics of emotions following a consideration of their linguistic aspects.

Abu-Lughod (1990:2) tells us that "emotions are about social life rather than internal states." What can be more social than language and discourses themselves? Language is the codified medium through which people put their feelings into words ${ }^{49}$ and also reproduce normative discourses. Moreover, following Ahmed, we should recall that "naming emotions involves different orientations towards the object they construct" (2014:14).

The particularity of a transnational context concerning language lies in its hybridity. In my case study, Italian, along with associated gestures, is intermeshed with

\footnotetext{
${ }^{48}$ Culture is conveyed through popular television as well as during people's everyday interactions.

${ }^{49}$ In Veiled Sentiments. Honor and Poetry in a Bedouin Society (1986), Abu-Lughod investigated the prescribed ways in which women within a Bedouin community in Egypt had to display their emotions through poetry. Subsequently, there has been increasing interest in "other" linguistic conduits of emotion. Here, I am referring only to normal conversations exchanged between women. However, as I have already emphasized, the particularity of a transnational context manifests in the hybrid use of different languages to convey life stories or sentiments.
} 
Arabic - with important differences between Italy and Morocco in this regard - to better convey feelings ${ }^{50}$. When translated in a different context, emotions sometimes transform and give life to something altogether different. In fact, as Abu-Lughod (1990:7) points out, "emotion gets its meaning and force from its location and performance in the public realm of discourse." It is therefore impossible to talk in terms of "pure" or "stable" emotions in light of theoretical advances contributed by scholars such as Judith Butler and Rosi Braidotti. I argue that emotions are necessarily "performative" and, in the specific context of my transnational case study are "nomadic"51 (Salih, 2003).

Of course, the reproduction of cultural normative patterns is manifested through language. However, as Berlant points out:

Who is to say whether a love relation is real or is really something else, a passing fancy or a trick someone plays in order to sustain a fantasy? This is a psychological question about the reliability of emotional knowledge, but is also a political question about the ways norms produce attachments to living through certain fantasies. What does it mean about love that its expressions tend to be so conventional, so bound up in institutions like marriage and family, property relations, and stock phrases and plots? (2012:6)

But, as we have already seen, desire, and therefore love, are also manifested and lived through embodied experiences. For Michelle Rosaldo (cited in Esteban, 2008), emotions are embodied thoughts, and, therefore, exhibit multiple variations, depending on the culture. For Esteban Galarza (2011), love as an interaction, involves the body like any other form of social interaction. Thus, she argues:

One can maintain that love interaction is embodied and therefore for the same reason could be dis-embodied and re-embodied: sensations and perceptions repeat but modify, voluntarily or not, in a way that some determined combinations can give life to others. $(2011: 43)^{52}$

\footnotetext{
${ }^{50}$ As an example, Soumaya Naamane Guessous begins her book Au-dela de toute pudeur. La sexualité feminine au Maroc (1991) by explaining why it is impossible to exactly translate "Hchouma," an emotion associated with social, religious, and cultural norms in Morocco. It sometimes conveys shame, sometimes modesty, and sometimes neither. Talking about sexuality and love is considered "Hchouma," though it must not be confused with "Haram," that refers to what is forbidden in Islam.

${ }^{51}$ See note 43 and 45 .

${ }^{52}$ My translation of the Spanish text.
} 
For Ahmed, "emotions shape the very surface of the body" (2014:6), showing how one's past remains visible. She states: "Emotions show us how histories stay alive, even when they are not consciously remembered" (Ahmed, 2014:202).

\section{Capitalism (not the Beatles) taught you that "love is all you need"}

The romantic ideological myth is the quintessential and original ground upon which capitalism developed and grew (Federici, 2012), and media such as television are a functional instrument for the expansion of its ideology. In fact, the Western idea of romantic love was birthed during the historical changes that led to the ordering of nation-states led by the new capitalist economy. The birth of this order, structuring people's sentiments and channeling them into the institution of the mononuclear family, which was fundamental to social cohesion, led the way for an exclusive binding of love and marriage (Coontz, 2006). Other kinds of sentiment that did not target the husband/wife equation as the one important to the community were progressively discredited (Esteban, Doménech, Távora, 2005). Emotions, as framed by the capitalist neo-liberal economy, are thus a "growing market" (Esteban, Doménech, Távora, 2005).

Romantic love was born in ancient times, but its emergence as the top fashion product of capitalism only occurred when capitalism succeeded in selling the heteronormative and reproductive life as the most charming of dreams. ${ }^{53}$ Consequently, the binding of love and marriage developed in non-Western cultures, as well, through the strategic colonization by the Western capitalist order (Davis and Davis, 1995; Esteban Galarza, 2008). Anthropology, and feminist ethnography in particular, has played a fundamental role in revealing native ways of living emotions within the non-Western world $^{54}$ (Maher, 1989; Abu-Lughod, 1986). Romantic passion turns out to be the pivot for the social system's reproduction, achieved by domesticating and morally embedding

\footnotetext{
${ }^{53}$ Contemporary feminism is currently struggling, indicating that neoliberalism, following the same strategy after having transformed sentiments into selling products, is manipulating feminism itself, transforming it into its latest "in vogue" product and depriving it of any meaning.

${ }^{54}$ Chapter Three reveals ambivalences in managing a "Western" conception of love and the existence of other kinds of love, not just for children or friends, but also for couples.
} 
sexuality (Esteban, Medina, Távora, 2005), in contrast with more ancient ideological bases, especially that of Islam (Mernissi, 1975).

\section{The hidden face of love in Islam}

Notwithstanding similarities regarding the normative gender roles of women and men within the three main monotheistic religions, there are some huge discrepancies underlying their dogmas regarding the differences between the sexes. My main interests are in exploring Christianity and Islam in this thesis, and Fatima Mernissi's work is critical in this area, being among the first to dismantle Orientalist stereotypes relating to Arab Muslim women's bodies (Mernissi, 1975, 1988, 2000). The author undertook a comparative study of Freud's importance within Western ideology and that of Imam Ghazali (1050-1111) within the Muslim world (Mernissi, 1975). Mernissi showed that Imam Ghazali's interpretation of the Qur'an was based on the absence of a male/female polarization concerning sexuality, which is contrastingly at the core of Freud's psychoanalytical theory. Imam Ghazali "conceive[d] of both male and female sexuality partaking of and belonging to the same kind of sexuality" (Mernissi 1975:47), and he even granted females "the most uncontested expression of phallic sexuality: ejaculation" (Mernissi 1975:48). From a Western Christian perspective, Imam Ghazali's ideas, especially concerning sexual intercourse, are unexpected and remarkable, given the period of his writing ${ }^{55}$.

Contrasting with Freud, for whom "to love an object is to attempt to master it, to seek to destroy its alterity or Otherness" (Berlant, 2012:25), Imam Ghazali did not identify any aggressor nor victim, "just two people cooperating to give each other pleasure" (Mernissi, 1975:48). There is neither an active nor a passive subject in his vision with regard to sexuality and all other spaces of life.

\footnotetext{
${ }^{55}$ This kind of thoughts, that I provocatively label "modern", applying a postcolonial critical lens, are still a distant possibility not only within the Christian religion, but also in all other Western - or at least Italian - public settings, within which religion's paralyzing concepts continue to silently overflow.
} 
Imam Ghazali's owe of the overpowering sexual demands of the active female appears when he admits how difficult [it] is for a man to satisfy a woman (Mernissi, 1975:50)

Therefore, the conceptions of Islam and Christianity clash, even though we must acknowledge the huge diversity of interpretations of the Qur'an since Mohammed's death, and the changes in the way this religion has been understood and lived. While the geopolitical modern asset, colonization, and the encounter with the West reinforced women's segregation and changed some of the practices between women and men, thoughts such as those of Imam Ghazali's are nonetheless important for understanding the ideological basis of Islam. However, we must acknowledge that such ideological notions are clearly not to be considered a guarantee against gender violence and women's subordination within the Arab Muslim world. Mernissi affirms that:

[Imam Ghazali] sees civilization as struggling to contain women's destructive, allabsorbing power. Women must be controlled to prevent men from being distracted from their social and religious duties (1975:42).

\section{Love and Migration}

When introducing the topic of love in relation to migration, we must start by reviewing the existing literature. This reveals its paucity, including anthropological literature, on the broader topic of emotions and globalization (Svazek and Skrbis, 2007; Mai and King, 2009), let alone studies specifically on love in the lives of migrant women. At times, the crisis of masculinity (Treacher Kabesh, 2013b), and women's more evident agency may give rise to new types of coupling relationships that are often detrimental to women, sometimes leading to violence (Bimbi, 2011; D’Odorico and Vianello, 2011; Menjivar and Salcido, 2002) or, in the best of the cases, to the end of the relationship (Barriteau, 2011). Conversely, at other times, the reinforcement of normative masculinity in combination with women's lack of social support may lead to the strengthening of male control-either through religion or other justification-over women's bodies (Bartolomei, 2007) ${ }^{56}$.

\footnotetext{
${ }^{56}$ Further research is needed to determine whether one or more of these situations actually occurs in connection with migration. This could help improve women's daily lives. Alternatively, it could shed
} 
Svazek and Skrbis (2007:372) have described the experience of being totally immersed in globalization and, consequently, of individualism, as an "ongoing emotional struggle". Men's insecurity and the resultant crisis of masculinity in a migratory environment that fosters their identification as strangers could, I suggest, be followed by what Ahmed refers to as "sentimentalization" of a "space of belonging" (1999:341). This process causes men, in particular, to revert to what they consider the purest of traditions. These are often equated with the oldest patterns of patriarchy that are extremely detrimental to women, and to types of behavior that foster men's power above anything else. Men's adultery is one example of their need to demonstrate their role and prerogatives (Boehm, 2011; Kipnis, 2000). Writing along the same lines, Boehm (2011:101), who studied a transnational community between Mexico and the United States, highlighted "the disloyalties and infidelities that emerge from the global economy." She used Appadurai's (1989) theory that "diasporas [...] create new maps of desire and attachment" and result in the "grinding of emotional gears" to explain this phenomenon (Boehm, 2011:101). Her study attests to this common occurrence in contexts of geographical separation between wives (living in Mexico) and husbands (living in the US). The same phenomenon featured in the stories of the women I interviewed, with husbands committing adultery in Italy while their wives were in Morocco. Women, as for Boehm's case, often overtook that situation. This could be due to the social code impelling women to retain their role as good and loyal wives, no matter what, or to their belief that their relationships with their husbands entail something more important to be safeguarded than sexuality itself. One possible option, beyond the intangibility of sentiments, could be the importance accorded to the materiality of objects and money. Nonetheless, as my study reveals, men commit adultery even when their wives are also in Italy and no physical distance between them is involved. One aspect of this topic that interested me, and that featured in my case study, was women's adoption of more "flexible" opinion and practical behaviors relating to extremely charged topic to safeguard their marriages and the associated economic support. A key example in this regard is abortion ${ }^{57}$.

\footnotetext{
light on a less discussed, and perhaps less anticipated, facet of migration than one of "emergency": women's empowerment.

${ }^{57}$ Even if the women I interviewed did not practice it themselves, or at least they told me so, they did not seem to impute a high degree of moral value to it, considering it as a practical matter. See Nadia M. story in Chapter Three.
} 
The relevance of capitalism and its associated geo-politics to a study of love relationships in the context of migration needs to be stressed. The capitalistic strategy of "individualizing" people is achieved through two tactics in particular. One celebrates "self-made men" as its most accomplished and "cool" subject, but does not celebrate women. However, a consideration of women as "self-made" subjects, but not in the prevailing economic sense is central to this thesis. The other strategy entails the stricture invoked by the popular saying that "dirty linen must not be washed in public." Both strategies involve emotions.

This process of individualization involving living emotions during the stage of capitalism, and even more so under the current stage of neoliberalism (Federici, 2012), has remained veiled even to researchers. Heterosexual love, as the most secret and private emotion, has been distanced even further from its bond with history, geography, and economy that represent the explanatory keys to complex contemporary relationships (Mai and King, 2009). In this regard, it is particularly relevant to anticipate how, for the mostly Moroccan migrant women whom I interviewed, materiality and money, more than some intangible sentiment of "love," were key underlying factors in their relationships. I would argue that this aspect, already present in men's and women's relationships in their native country (Morocco) before the current neoliberal geopolitical asset (Mernissi, 1988; Maher, 1989; Esteban, 2008), represents the most fundamental aspect that nowadays leads to violence and the breaking up of relationships when migrating to the West. The economic crisis, racism, and other layers of discrimination play a fundamental role in constraining men's ability to achieve for themselves, and for their families, the lifestyles that they would hope and expect, from an economic perspective, to attain. Moreover, as Faier (2011) observes, competition over jobs in a Western context often do not translate into forms of male solidarity among compatriots abroad. This characteristic in fact weakens men's subjectivity within the diaspora, corroding some of the traditional forms of community-based socialization. These aspects that relate to men, combined with women's often secret initiatives and aptitude to find work in an increasingly aging Europe ${ }^{58}$ where the services they provide as caregivers are widely in demand, leads to a clash of normative paradigms and tasks of both women and men within the traditional family.

\footnotetext{
${ }^{58}$ The sociologist Arlie Russell Hochshild terms this phenomenon "global care chains."
} 
Medina Doménech (2012) suggests, along the same lines, that while emotions have individual and collective meanings, they become personified in relation to specific social and material contexts, informed by specific economic conditions. Noelle Stout (2014) was led to the same conclusion in her ethnography about Cuba. She stated that it was only when we start from a position of "connecting love and intimacy to broader social systems that foster inequality, such as colonialism and, more recently, neoliberalism and global capitalism," can we "begin to understand how oft-assumed private feelings generate inequalities" (p. 188). ${ }^{59}$

We should also be aware that racism and ethnocentrism have always applied to matters such as emotions, beginning with Freud's book "Totem and Taboo." ${ }^{\prime 60}$ Such "colonialist" ideas still apply when it comes to differentiating what Mai and King (2009) refer to as "Northcentric" civility' from all "other" civilities. As they note:

Because of their deep resonance within ideologies and practices of modernization and of the celebration of courtly love's respect towards women as a founding institution of European political and cultural civilization, ideologies of romantic love have played (and still play) a key role in the construction of Europe in terms of moral and civic superiority. (2009:301)

This does not mean, of course, that "Northcentric" civility has reached gender equality generally, let alone in the emotional field. Contrary to mainstream ideas, evaluation and rationality in relation to emotions featured commonly and often characterized the women who were the subjects of this thesis.

More than restrictions of couple love, their families often constrain migrant women - especially those I interviewed - from acting freely in ways that they believe are better. The familiar extended family structure still seems to represent, at least in Arab countries, the strongest of bonds, irrespective of transnational boundaries and of the "extreme" life experience of living in a squat.

Geographical distancing from these strict family bonds can sometimes also represent an escape and liberation from them, opening up a space for subversive male-

\footnotetext{
${ }^{59}$ This quote is extracted from note 8, on page 188 of Noelle Stout's book "After Love. Queer intimacy and erotic economies in post-soviet Cuba," Duke University Press.

${ }^{60}$ Sigmund Freud, Totem and Taboo, 1913.
} 
female practices. ${ }^{61}$ The particular experience of living in a squat contributed to fostering unconventional lifestyles among the women subjects of my thesis.

Thus, if Arab women in particular manage to recreate solidarity with other women in a new environment, they can reproduce their typical "strategies" of mutual help (Maher, 1989; Mernissi, 1988), but with more freedom as a result of the distance from their country of origin (Morocco). This element is what ultimately contributed to their strengthening in every field, even the emotional one.

\section{The Personal is political: Why love is a properly political tool}

Second wave feminism has enabled us to make the claim that "the personal is political." The capitalist order aimed to make personal family life even more hidden and untouchable, distanced from communitarian mutual help. This deepened women's exploitation, both physical and emotional, within the boundaries of the home. Feminism's claim, from the sixties onwards, of the political relevance of personal life is still one of its top priorities. What can be more personal than romantic love itself? Even if we acknowledge the importance of culture and society in shaping love, it is indeed lived personally and walled in by codes of privacy and sanctity. Emotions are political tools (Svazek, 2010, Lutz and Abu Lughod 1990). They are especially so for feminism, because, as Esteban reminds us:

The qualities that define emotions define also women. For this reason, any discourse about emotions is also, at least implicitly, a discourse about gender. $(2011: 46)^{62}$

Love is then a "properly political concept" (Berlant, 2011:687; Medina Doménech, 2012). Once we have acknowledged its genesis within patriarchal culture (Svazek and Skrbis, 2007), unveiling its relationship with justice and injustice (Boehm, 2011; Ahmed, 2014), as well as magnetizing its "world building energy" and not allowing it to "atrophy" (Berlant, 2000) can prove useful. As Berlant states:

\footnotetext{
${ }^{61}$ The stories of Suad and Hanan, portrayed in Chapter Three, are representative of both women's empowerment regarding love, and of their attempts to transform traditional gender roles and obligations.

${ }^{62}$ My translation of the Spanish text.
} 
What would we do for love? What would we allow love to do to us? If money is the thing that increases our power under the current regime of value, how would our relation to desires and world become increased by exchanging, or circulating on the principle of love? (2011:686).

Because "love migrations" are an essential component of the "new map of migration" (Mai and King, 2002; Roca i Girona, Bodoque Puerta \& Soronellas Masdeu, 2012), and because the topic of migration is the most political of those currently featuring in international debates, the claim of love's political relevance in relation to transnationalism and diasporas appears to be a particularly valid one.

The aim is to build a theory about love that contributes to a broader rewriting of a "herstory" that can be modified and reshaped with the passage of time, but can also structurally resist this passage of time. This "herstory" should encompass geography, politics, colonization, history, racism, class struggle, and other fields to better narrate the story of when patriarchy invented love. In a just world, this could possibly serve as a tool to enable an individual to overcome the simultaneous tension between self-interest and other-oriented interest in matters of love that until now has posed the greatest obstacle for feminism (Jónasdóttir, 2011). 


\title{
Chapter Two: Migration
}

\author{
Un mundo en donde quepan muchos mundos. ${ }^{63}$ \\ Concepción política y poética del \\ Ejército Zapatista de Liberación Nacional (EZLN) \\ In una città di donne \\ nessuno sarebbe davvero povero. ${ }^{64}$ \\ Melania G. Mazzucco, Vita
}

\section{Introduction}

The right to move freely in the world constitutes a major challenge of contemporaneity. The latest incarnation of the master performer, neocolonialism, is that of global capitalism. Past predominance of Western states has now been substituted by that of huge transnational companies that appear to be unaccountable for their exploitation of natural resources and labor in Africa, Asia, Latin America and the Middle East on a massive scale. While these regions were openly described as "colonies" in the past, they were subsequently labeled as poor countries, the Third World, and the Global South, without any substantial accompanying change in their conditions.

Global capitalism continues to "impoverish" a great portion of these regions, applying different strategies that range from economic structural adjustment programs (SAPs) to more recent industrial practices and agricultural regimes ${ }^{65}$ that only allow free movement of goods, ${ }^{66}$ while categorizing people into those allowed to move and those who cannot. Television programs and the mainstream press daily broadcast news on the massacres in the Mediterranean, with thousands of people denied even the right to a name while European citizens experience mounting panic about being "invaded" by

\footnotetext{
${ }^{63}$ A world where many worlds could fit. Political and poetical manifesto of the EZLM (Zapatista Army of Nacional Liberation). (My translation from Spanish).

${ }^{64}$ In a women's city nobody would be really poor. (My translation from Italian).

${ }^{65}$ Neo-colonialism currently presents itself as transnational companies exploiting poor territories and imposing genetically modified products and seeds.

66،"Sending states" are not to be deemed innocent too. They disproportionately increased their economies' dependency on migrants' remittances, in so doing becoming complicit of global capitalism mechanisms of impoverishing the South of the world. Just to give the example of Morocco, after being overwhelmed by IMF structural adjustment policies, migrants' remittances represents its main source of income over the phosphate and the tourist industries (Al-Ali).
} 
those who appear different. Who has the right to live, according to very limited possibilities, and who must die, are determined by bio-politics and necro-politics (Foucault, 2008; Haritaworn, Kuntsman \& Posocco, 2014; Mbembe, 2003; Winter, 1994).

Women comprise a considerable proportion of the invisible people who risk migration, escaping to survive, following family members who have already migrated, or just a dream of improving their living conditions. Love and emotions feature in their migrations. They restructure families and contribute to the building of new forms of attachment, as this thesis will show.

This chapter begins by introducing some general characteristics of contemporary migration. It subsequently focuses on women's importance in migration. The following section focuses on migration to Italy, which transitioned from being a country of emigration to one of immigration, and finally to the current situation entailing both characteristics. ${ }^{67}$ The chapter concludes by highlighting the importance of squatting practices and squat associations for migrants.

\section{Confini / Borders}

Mainstream media, deploying refined discourses of "risk and "fear" (Svasek, 2010), presents contemporary migration, especially from Africa and the Middle East in terms of "emergency" and "invasion," as if they constituted a new phenomenon. This contributes, strategically, to the generation of "moral panic in European societies" (Lutz, 1997). The origins of these migrations can be traced back to the seventies (Anthias \& Lazaridis, 2000:2). In practice, migration is propelled by different motivations, wills, desires, and obligations (Svasek, 2010; Parente, 2012). ${ }^{68}$

Juliano (2012) suggests that xenophobia primarily results from the belief that cultures are totally incompatible, ${ }^{69}$ and that huge differences between them lead to aggressive behaviors that hinder "multiculturalism." Moreover, "difference" is

\footnotetext{
${ }^{67}$ The year of 2015 closed with 141,777 Italians less than the year before officially residing in the country (Istat, 2015). This is especially due to what is called "brain drain", the emigration of high-qualified young professionals especially to other European Countries, Australia and North America.

${ }^{68}$ Some are impelled by a mix of global capitalism's strategies of exploitation of their countries own economies, people and lands - mainly in terms of fossil fuel, agriculture and labor. This long and often savage process has many detrimental consequences for local people and their habits, modifying ancestral traditions, sometimes hardening its most conservative traits as a reaction, and giving birth to movement of Western haters, often leading to what the West labeled "terrorism", not without political interest.

${ }^{69}$ This recalls Samuel P. Huntington's - and others' - ideas about “The Clash of Civilization” (1996).
} 
considered to be something that affects each individual in a permanent and deep way that cannot be changed. The findings of this thesis contribute to the dismantling of each of these Western certainties that have forged a "cultural fundamentalism" (Juliano, 2012:527). It does so mostly by showing how identities are performed ${ }^{70}$ and that cultures are not static and fixed, but are able to simultaneously "melt" and be modified, incorporating different elements from "different" cultures. "Difference," then, is not something "monolithic"; rather, it is something composed of different layers, including religion, gender, age, and ability. "Difference" is not an axiom; it is created as a result of clear political interests.

A culturally embedded notion of citizenship enters the debate as the legal endorsement of this difference. Citizenship is still conceived as a "status" bestowed on those who are full members of a community. ${ }^{71}$ Nonetheless, as Yuval Davis argues, it is a "multi-tiered concept" determined by the combination of gender, age, religion, sexuality, rural or urban background, and ability (Juliano, 2012). ${ }^{72}$ All Western women have been neglected in the actual granting of citizenship, as they were excluded a priori from the patriarchal social contract. ${ }^{73}$ National welfare regimes are consequently linked to the notion of citizenship-based rights $\left(\mathrm{Al}-\mathrm{Ali}^{74}\right)$. Given differences that include their mother tongues and religions, migrant women are now in an even more vulnerable position regarding the possible achievement of this status (Salih, 2001).

Although visionary intellectuals had promoted innovative concepts such as "post-national membership" ${ }^{75}$ and the dissolution of the strict link between a nation-

\footnotetext{
${ }^{70}$ See note 43 .

${ }^{71}$ T.H. Marshall (1950), cited in Lutz (1997).

${ }^{72}$ Feminist ideas about intersectionality are fundamental in this regard, stressing the importance of the simultaneous account of all the mentioned aspects (Collins, 1998; Crenshaw, 1991).

${ }^{73}$ Modern patriarchy is in fact "contractual" (Pateman, "The Sexual Contract", 1988). At the origin of the ethical pact that established modernity as organized in rules, women were not considered among citizens. They were not free neither equal as men when those decided to find such an agreement, ceding part of their authority in order to establish a community. Ana Rubio (Universidad de Granada) and Rosa Cobo Bedía (Universidad de La Coruña) introduced me to the topic of modern patriarchy in feminist political and legal theory. Even if most of the women from "Fortress Europe" (Lutz, 1997) currently believe to be full legal members of their communities, it is not so regarding many points, starting from the manner in which national constitutions were written, by men's hands, going on to their actual representation in the political arena.

${ }^{74}$ Al-Ali, Nadje, "Women, Gender and Migration in Europe", http://www.comune.forli.fo.it/ Documenti/39/gender.pdf

${ }^{75}$ Granada's professor Ana Rubio introduced me to the argument. During the Noise summer school (Utrecht, 2015) I had the chance to get familiar with Isabelle Stengers' "Cosmopolitical Proposal" (2005).
} 
state and a national identity, initiating a debate on citizenship in Europe is harder than ever now. $^{76}$

Transnationalism is a fitting analytical mark for examining contemporary migration (Bartolomei, 2007; Bastia, 2009; Boehm, 2011; Coe, 2011; Faier, 2011; Salih, 2001, 2003; Zontini, 2010). Accordingly, global capitalism is considered as the driving force that propels migrants to build parallel worlds constituted by one or more nation-states (Bastia, 2009), melding together two or more cultures, without being especially assimilated into one in particular, while contextually performing ${ }^{77}$ their identities and remaining between two worlds. They are able to do so thanks to innovations such as faster and easier means of communication ${ }^{78}$ and transportation (Zontini, 2010). Nonetheless, transnationalism is not a "neutral space" (Al-Ali ${ }^{79}$ ), because like older concepts used to analyze migration, it often denies the important role that gender plays in this process.

Transnationalism, as applied in this thesis, especially impels a revision of traditional research methods, because it complicates the division and definitions of households and families as typical anchors of migration studies (Zontini, 2010). Households, considered as a group of people who share the same residence and participate collectively in the basic tasks of reproduction and consumption, as well as families, must be reconsidered in light of their current modifications and adaptations. Contemporary transnational households must be analyzed, taking into consideration the frequent lack of a physical unit and co-residency (Salih, 2001), and the "union" of a family that is mostly based on remittances and online communication. Moreover, what must be stressed are the consequences that "precarious" living conditions, such as living in squats, bring to family life and couples. All of the aforementioned aspects directly affect emotional lives and love. This thesis, therefore, argues for a new theory of migration that incorporates emotions and the fundamental roles that family and love

\footnotetext{
${ }^{76}$ While I am writing this thesis, United Kingdom has decided to exit from the European Union with the famous "Brexit" referendum, being the first to crash the visionary ideal of an inclusive "European culture". In the meantime, Republican candidate Donald Trump is running to become next USA president against Democrat Hillary Clinton, basing all its propaganda upon a very strict and unreal ideal of citizenship, excluding undesired migrants from its borders.

${ }^{77}$ See note 43 . A particular example from my case study is the contextual use the women interviewed made of the Islamic veil. Most of them in fact wear it when in Morocco and do not when in Italy. This element will be clarified in detailed in Chapter Three.

${ }^{78}$ The use of new media technologies such as WhatsApp by the women subjects of this thesis will be deepen in Chapter Three. See then Appendix Two for some of their Whatsapp profile pictures.

${ }^{79}$ See note 74 .
} 
play in it. We need to start by framing a "counter-geography of globalization" (Sassen 2000, 2003).

\section{nómadas: migrant women}

Women represent a major proportion of the brave people who try to change the course of their everyday lives. However, they are often invisible to the Western eye, as the "neglected actors of globalization" (Zontini, 2010:1). Some of them drown in the Mediterranean Sea, ${ }^{80}$ while others, such as Nigerian and Eastern European women, are caught in the nets of sexual exploitation. Some are harassed and murdered in the train dubbed "La Bestia" ("The beast"), used by many illegal people trying to cross the Mexican-US border. ${ }^{81}$ Many are compelled to leave their countries in ruins, having to find the strength to drag themselves, carrying their children, from one dusty border to another.

Women migrate for a wide variety of reasons that do not confirm with a strict binary categorization as either migrants for work or migrants for love (Parente, 2012). Women do migrate alone, sometimes becoming successful adventurers, despite the difficulties they face (Chell-Robinson, 2000), and, through their empowerment, transnational models for their female compatriots. Women have always migrated, even within the boundaries of one country, moving from rural to city contexts. Some have been divorcees or widows. Others have simply been "hurryiat" or free women as a result of their life choices (Maher, 1989). Women are also the most affected by extreme poverty resulting from various causes like SAPs or climate change outcomes. The "feminization of poverty" is undoubtedly one of the propelling factors behind migration (Bastia, 2009).

\footnotetext{
${ }^{80}$ It is not possible to find any gender sensitive survey regarding deaths in the Mediterrean sea. As a consequence, we cannot know how many migrants and refugees who died in such a terrible way were women. According to IOM (International Organization for Migration) in 2015 migrants who died in the Mediterrean sea were 3770. Source: https://www.iom.int/news/over-3770-migrants-have-died-tryingcross-mediterranean-europe-2015 (Last access on July 31th 2016). More information about 2016 can be found at the following website: http://missingmigrants.iom.int/latest-global-figures (Last access on July 31th 2016).

${ }^{81}$ Otherwise called "The death train". Margarita Trejo Velasco, from the GEMMA Erasmus Mundus Master's Degree in Women's and Gender Studies, conducted an excellent feminist ethnography in 2015 in Mexico among women who undertake such high risky migration. I am especially thankful to her work and her friendship.
} 
Women do find various ways to escape becoming victims subjugated by religion, culture, marriage or the family (Morokvasic, 1984). Non-Western feminists ${ }^{82}$ have taught White Western feminists not to victimize "other" women. Recalling that strategic discourses of victimization tend to fall into line with women's real strategies, such lessons must also be applied to the field of migration (Juliano, 2012).

The multiple feelings and motivations underlying women's decisions to migrate are indicative of the importance of emotions ${ }^{83}$ as fundamental key for understanding their lives in the era of globalization. Moreover, migrant women are even more excluded in the new country as a result of the intersection between racism and sexism (Anthias, 2000).

In practice, the escape from one hell propels them straight into another, in which they are denied the right to work, or are exploited, forced to do jobs deemed a "blessing of the modern societies to Third World Women" (Morokvasic, 1984:889). ${ }^{84}$ Migrant women mostly do the kinds of work that Western women no longer want to do, in light of their perception of final "emancipation" from being cleaners or caregivers of the elderly. However, this emancipation is just an illusion: Western women often continue to be the sole care providers within their own families. Nonetheless, some of the emancipation experienced by Western women has undoubtedly entailed other women's exploitation (Andall, 2000).

Migrant women often have to cope with a changed familial situation upon their arrival in the new country and their reunification with their already migrated husbands. A crisis of masculinity affecting their husbands (Treacher Kabesh, 2013b), poor living conditions, and a xenophobic environment may contribute to deteriorating relationships. The behavior of their partners could even extend to psychological as well as physical violence inflicted on their bodies. Under these harsh conditions, women often manage to cultivate emotional and affective bonds. ${ }^{85}$

However, current theories of migration tend to be "gender blind" in relation to the above issues (Anthias \& Lazaridis, 2000:17). From the legislative perspective,

\footnotetext{
${ }^{82}$ Postcolonial feminists, Black feminists, African feminists, and Islamic feminists among others.

${ }^{83}$ Emotions are, in fact, normally implicitly subsumed into the discussion about globalization. But globalization creates new types of experiences associated with "risk-taking, experimentation, and selfexpression (Svasek \& Skrbis, 2007).

${ }^{84}$ Bastia (2009), citing the case of England, affirms that sometimes women are even attributed the less valued kind of works because of their lowest skills, so that they can obtain just short working permissions.

${ }^{85}$ Chapter Three will focus on those women's stories and their "love" relationships in migration, both past and present.
} 
migration still addresses men as its proper subject, with women considered their dependents (Juliano, 2012). This is evidenced in family reunification, which still affords one of the easier legal routes for women's migration (Lutz, 1997). Moreover, the concept of family that is the object of European policies and regulations is one that is mononuclear and based on the "male breadwinner principle" (Lutz, 1997:104). It denies "different" family structures that include social parenthood, and "different" models that envisage women as the main family earners.

For a woman to prove her relationship with a man in family reunification applications, she generally has to:

Prove the quality of their relationship, namely that the marriage was not motivated by considerations other than affection and love, thereby introducing the romantically idealized love-marriage as a yardstick of legality. (Lutz, 1997:104)

Feminists have shown that the equation between Westernization and gender equality is an ambiguous one (Morokvasic, 1984). This is particularly true for love, which is strongly characterized by unequal power relationships. ${ }^{86}$

Moreover, maternity contributes to the difficulty of women's migration, or impedes it. Women struggle to make a living for themselves and their children. They frequently have to cope with the stigmatization they feel, corporeally, as mothers who left behind and, in some way "abandoned" their children, even if not economically (Coe, 2011), in their countries of origin (Zlotnik, 1995) ${ }^{87}$

In general, more migrant women than men are illegal (Bastia, 2009). This makes them invisible and compels them to deploy a variety of illegal practices, such as squatting, as survival strategies.

A large proportion of migrant women are employed outside of the home. In fact, these women "provide the flexibility that global capital needs" (Anthias, 2000:25). While they may consider that their familial need justifies their poor working conditions, (Morokvasic, 1984), they are integral to world, caring for life itself, therefore enabling Western societies to continue to function, undisrupted. In southern European countries such as Italy, the work of caregiving is largely un-regularized.

\footnotetext{
${ }^{86}$ See Chapter One.

${ }^{87}$ As Zlotnik (1995) noticed, this is extremely evident in the case of Filippine migrants for care work, who mostly left their children back home.
} 
Women caregivers often exchange patriarchal subjugation within their own families for that within their employers' families. Similarly, illegal migrant women who have been incorporated into factories are the most exploited factory workers, and do not benefit from the achievements of the global workers' movement (Morokvasic, 1984). ${ }^{88}$ The incorporation of women within waged employment brings about what Morokvasic has called "pseudoemancipation" (1984:893), given the concurrent gains and losses in their lives. In the case of Western women, this has been particularly evident in terms of changes in the family structure and increasing divorce rates. ${ }^{89}$

Working allows or obliges women to send remittances back home. Women are generally more inclined to remit money on a regular basis than men (Bastia, 2009). I conjecture that irrespective of their working situation, their gender role and social obligations make them generally more reliable than men. Moreover, sending remittances may represent a way for them to free themselves from social control exerted from the home country (Zontini, 2010). Money, and its use, empowers women.

\section{The Italian context}

Apart from its physical contours that resemble a bridge extending from northern Africa to Europe, and its geographical position, positioned exactly in the middle of the Mediterranean Sea, Italy has been widely considered a country of extensive emigration. This trend began during the seventeenth century, with millions of Italians pursuing a promising future in the United States, followed in the nineteenth century by further southbound emigration to Latin America. Accustomed to this outgoing trend, Italy suddenly woke up late to the fact that it had become a destination for others, especially in light of the second economic boom of the 1990s. ${ }^{90} \mathrm{We}$ should note that unlike the Netherlands, Belgium, France, England, and Spain, Italy did not have a significant

\footnotetext{
${ }^{88}$ In this regard, the case of chinese women illegal workers in chinese factories in Italy is extremely relevant. Most of the Chinese community in Italy seems to create a parallel world where institutions and law do not enter. Migrant women, are often deported just for working illegally enclosed in factories for many years. More information on the work conduced by an Italian feminist organization can be found here: http://www.ingenere.it/articoli/sfruttamento-donne-cinesi-italia

${ }^{89}$ Zlotnik (1995:265) already noticed in her study in 1995 that divorce rates among migrant women where especially high. She motivated her statement relying on migrant women's achievement of more self-assurance in a foreign context.

${ }^{90}$ Italy experienced the first economic boom in the Sixties, after World War II. During this period most of the modern country's infrastructures and world famous companies were established and find a huge development.
} 
colonial past (Zontini, 2010). This factor, combined with the country's previously economically weak situation, contributed to its delayed emergence as a migrant destination. Nonetheless, beginning in the late eighties when the first Moroccans arrived (Salih, 2001), and continuing through the nineties, a great wave of migration flowed from Eastern European countries, following the political dissolution of the Soviet bloc. ${ }^{91}$ Preparing for the future was not a political priority for Italy. ${ }^{92}$ Consequently, it has been the target of millions of migrants and refugees who have arrived there in recent years, following tragic geopolitical trajectories centering on "invasion" and "emergencies" that have also been instigated by the West. The country's institutional structures and their employees are often inefficient in order to operate properly, with the complicity of the European Union ${ }^{93}$

Migrants in Italy encounter a very complex situation resulting from the coexistence of several negative factors that I describe below. The first is the deep and enduring north-south geographical division entailing significant economic and cultural differences. The South has never succeeded in freeing itself from widespread illegality and poverty (Salih, 2001). Second, the Mafia has played a role in maintaining this division and constituting "another state inside the state" for the South. The Mafia is implicated in the management and exploitation of migrants at many levels. ${ }^{94}$ Moreover, the informality and inefficiency of the bureaucracy has apparently given rise to a "jungle situation" (Lutz, 1997:104) that migrants must keep abreast of, and wherein it is crucial to "know someone" in every field of life. Lastly, the Catholic Church has played a role in forging a national identity based, importantly, on religious roots (Zontini, 2010).

All of these factors have contributed to amplifying differences from "the other." ${ }^{95}$ Given widespread illegality that contributes to migrants' invisibility in the eyes

\footnotetext{
${ }^{91}$ Italy was the target especially of migrants from Albania and Romania.

${ }^{92}$ First immigration centers were established in 1990 (Chell-Robinson, 2000). In 1987, 1990 and 1996 there were three great Amnesties aimed at regularize illegal migrants in the country (Salih, 2001).

${ }^{93}$ The European Union established especially with Article 13 of the Dublin treatise (1997) and its consequents Dublin II (2003) and Dublin III (2013) that asylum seekers were of the competence of the country where they illegally arrive, i.e. mostly Italy, Spain and Greece. http://www.lastampa.it/2015/09/06/esteri/cosa-prevede-il-trattato-di-dublino-e-perch-litalia-lo-vuolecambiare-ImRFPSmHhWANp4UqSXjVbO/pagina.html (Last access on July 31th 2016).

${ }^{94}$ Different mafious associations are implied in migrants' exploitation especially in agricolture as well as in their bureaucratic process towards legality. More info to be found here: http://espresso.repubblica.it/attualita/2016/05/12/news/il-caporalato-e-l-agromafia-un-economia-illegaleda-17-miliardi-di-euro-1.265135 (Last access on July 31 th 2016).

${ }^{95}$ Words used to refer to migrants range from "extracomunitario/a" to "clandestine". Anyways, at least in bureaucratic procedures, the terminology used is going towards a progressive sensibility (Orsini Jones \&
} 
of the state, citizenship is relatively difficult to acquire in Italy, and is conceded only as "ius sanguinis", a right of blood. ${ }^{96}$

Singly migrating women were actually the first to arrive in Italy. From the seventies onward, facilitated by different Catholic associations, ${ }^{97}$ women began to arrive from the Philippines to perform care work (Andall, 2000). Because of their religious beliefs, they did not pose a "problem" and for a long time remained unnoticed and invisible. Prior to the onset of more conspicuous male migration, women were not considered an "emergency." Women seem to have gained at least a small degree of visibility in the political arena as a result of men's migration (Orsini Jones \& Gattullo, 2000).

Morocco has long been an established "labor-exporting country" (Salih, 2001, 2003). Heading first in the direction of northern European countries-France, Belgium, and the Netherlands-Moroccans then turned their attention to Italy and Spain. The majority of Moroccan migrants currently live in these two countries (Zontini, 2010). ${ }^{98}$ Legally registered Moroccan migrant women represent almost half of the Moroccan population in Italy. ${ }^{99}$ Between the eighties and the nineties, many Moroccan women arrived alone (Salih, 2001). They mostly originated from Casablanca and its suburbs, and, as for women from the Philippines, they were educated and not from the poorest strata of their society (Zontini, 2010). Migration does not, therefore, appear to have represented a matter of survival for them (Zontini, 2010). Yet, being unable to afford the rent of a house in Morocco-let alone buying one-was a recurrent theme in my interviews.

Gattullo, 2000). "Extracomunitario" (someone who comes from outside of the community, i.e. the European Community) is not as used, for example, with reference to someone coming from the US or Australia, as it is for people coming from Southern or Eastern countries - Romania, Albania, Moldavia etc. Wendy Pojmann (2006) reflected upon this topic as a US citizen studying women migrants in Italy. Nonetheless, "Immigrato/a" (immigrant) is the most widely used word, from official to unofficial situations, while "migrante" (migrant) is almost un-used. "Immigrato/a" gives, in my opinion - even because the Italian grammatical form - a sense of stasis, immobility and passiveness, while "migrante" gives the sense of a process in transit and taking shape.

${ }^{96}$ It is not, in fact, accorded as a right of birth in the State territory, "ius soli". Information about the law can be read here: http://www.interno.gov.it/it/temi/cittadinanza-e-altri-diritti-civili/cittadinanza

${ }^{97}$ Acli-colf were the first Catholic associations involved with migrants women from the Seventies. Thanks to their work, migrant caregivers, who have a legal working contract, can demand some Italian workers" rights, including the "13esima mensilità" payment, an additional paid month every dependent worker has the right to (Andall, 2000).

${ }^{98}$ Given the last census of other citizenships legally residing in Italy, Moroccan were 452,424 upon a total of 4,570,317 foreigners www.istat.it/immigrati/indicatori-sintetici/profilo-per-cittadinanza (Last access on July 31 th 2016).

99 They exactly represent $43,66 \%$ of all legal Moroccans residing in Italy www.istat.it/immigrati/indicatori-sintetici/profilo-per-cittadinanza (Last access on July 31th 2016). 
Those women, who did not come through family reunification, or who came on a tourist visa and subsequently lived illegally with their families in Italy, decided to migrate alone for a variety of reasons (Parente, 2012). Undoubtedly, many of them aimed to somehow change their subalternity, experienced daily in their own country because of normative gender roles (Parente, 2012). ${ }^{100}$

Moroccan women are mostly employed in the caregiving sector (Salih, 2001), even though they are disadvantaged because of their religion and the stereotypical xenophobic way in which this is perceived (Zontini, 2010). ${ }^{101}$ Some are employed in small industries (Salih, 2001). ${ }^{102}$ Caregivers as well as factory workers generally do not have regular working contract (Andall, 2000; Salih, 2001). One should note that in light of the prevailing familial model of welfare in Italy and southern Europe, in general, the role of migrant women in Italy is especially important, first as caregivers and second as mothers themselves. Reproduction among migrant women contributes to the attenuation of Italy's progressive demographic decline (Salih, 2003). ${ }^{103}$

A final key point to note is the extent of continuing economic crisis in Italy. Originating in the US bank and mortgage crisis in 2007 (Walby, 2015), Southern European countries within the EU were subsequently badly hit. ${ }^{104}$ The residual effects of the crisis are still manifesting in Italy's economy and its political choices, in a compulsory way as well as in its use of the "crisis" to justify legal changes (Walby, 2015), especially moving toward greater "flexibility" in the working context. ${ }^{105}$ The economic crisis has heightened the fear of job loss among Italians, consequently

\footnotetext{
${ }^{100}$ Sometimes, irrespective of their being long term migrants or just arrived refugees, women dream of moving again, or moving elsewhere where life for them, as women, could be better.

${ }^{101}$ Interviews in Chapter Three will clarify Muslim women's disadvantage when searching for a job in Italy. Zontini (2010) identify the following kinds of excuses adopted by the employees while discriminating them: "I don't want them because with all those veils they cannot move properly"; "...because they don't eat everything"; "...because children might get scared"; "My mother is old and is not used to them".

${ }^{102}$ Of the ten women squatters, only Fatima, from Tunisia but who spent many years living in Italy, was employed regularly, even if poorly paied, in a factory outside the city.

${ }^{103}$ This represents a fundamental aspect taken into account by national politics. Istat, (2015), Bilancio

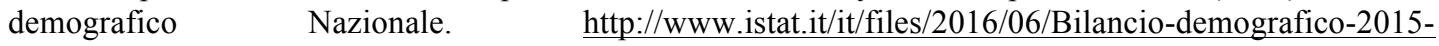
1.pdf?title=Bilancio + demografico + nazionale $+-+10 \% 2 \mathrm{Fgiu} \% 2 \mathrm{~F} 2016+-+$ Testo + integrale.pdf http://www.ilsole24ore.com/art/notizie/2014-02-11/popolazione-crescita-grazie-immigrati114440.shtml?uuid=ABDXFov\&nmll=2707\#navigation (Last access on July 31 th 2016).

${ }^{104}$ Greece faced the worst fiscal and economic crisis of the continent, followed, at the same level, by Spain and Italy.

${ }^{105}$ The Italian "Jobs Act" of the current Renzi government pushed towards more "flexibility" of working times and contracts in the labor market. This is producing greater precariousness from factory to cognitive workers. More info can be found here: http://clashcityworkers.org/documenti/analisi/2109-truffa-jobsact.html\#2 ; critics form a gender perspective can be read here: http://27esimaora.corriere.it/articolo/boldrini-loccupazione-femminilee-unarma-antiviolenzama-il-jobsact-non-sta-aiutando-le-donne/ (Last access on July 31 th 2016).
} 
accentuating their xenophobia. This has directly affected migrant women as workers and reproducers. The crisis, moreover, has disadvantaged both Italians and migrants in terms of their living and housing conditions.

\section{Squats and migration}

The right to housing is explicitly recognized as a basic human right in many international conventions (PICUM, 2004). ${ }^{106}$ Especially in view of the current and never-ending state of "crisis" that Italy is facing, the housing problem has escalated into a state of widespread precariousness of living that equally affects both migrants and Italians. Italy is still far from conforming to compliance of the housing right, entailed in the Habitat Agenda of the UN of which every member state is a signatory (PICUM, 2004). However, waiting lists for popular houses are mostly nonfunctional or entail years of enduring bureaucratic procedures.

Undocumented migrants, along with refugees, face the worst situation, with no available solution other than illegally occupying buildings. Yet, they are not explicitly mentioned in the above cited declarations (PICUM, 2004).

Squatting, defined as "living in or using a dwelling without the consent of the owner" (Mayer, 2013:2), is a practice that takes many different forms. In many cases, it is primarily intended as a political re-appropriation of public spaces for producing alternative knowledge and revolutionary practices critic of capitalism's injustices. These are spaces of "eterotopia" (Lefebvre, 1972 ${ }^{107}$; Cioce, 2014-2015); spaces of possibility, where "something different" can happen. Beginning in the sixties, many squats around the world have served this critical political goal. At other times, squatting is a matter of life itself. Squats for living purposes are inhabited by subalterns: impoverished workers or unemployed people from the outskirts of the metropolis, persons previously considered legally insane who continue to be socially marginalized, ${ }^{108}$ and illegal migrants. Both as a political and living medium, squatting could be regarded as a radical

\footnotetext{
${ }^{106}$ Among others, and significantly, it is included in the Universal Declaration of Human Rights (UDHR), in the Convention of the Elimination of All Forms of Discrimination against Women (CEDAW, 1979) and in the International Convention on the Protection of the Rights of All Migrant Workers and Members of Their Families (1990) (PICUM, 2004).

${ }^{107}$ More information about Harvey's, Foucault's and Lefebvre's ideas about spaces can be found here: http://www.heterotopiastudies.com/harvey-lefebvre-foucault/

${ }^{108}$ One of Florence oldest squat is that of the abandoned mental hospital of Via Aldini, where twenty years ago the first squatters even find restrain beds for children (Cioce 2015).
} 
act critiquing the status quo and transforming social relationships. It is frequently an emancipatory and empowered practice, as evidenced in this study. Squatters are often among the most rejected members of a society. Such subaltern positions may lead to a questioning of normative gender roles. Historically, feminist and queer squats have represented fundamental sites from where to rebel against patriarchy. ${ }^{109}$ This study argues that squatting practices among migrants demand the rethinking of affective relationships that have so far only been examined within families and households. Migrant squatters give birth to something new that replaces and restructures the traditional nuclear family. The community that the subjects of this study have built is a significant example.

Squatting in Italy has a long history. It encompasses both private houses as well as a large number of huge public buildings, abandoned because of the state's inefficiency and corruption. Central Italy, and especially Tuscany, the site of this study, and Emilia Romagna are historically known for their Communist past and their leftist politics and activism. Consequently, the national squatting movement, Movimento di Lotta per la $\mathrm{Cas}{ }^{110}{ }^{10}$ has a particular presence and prominence in this region. In these times of crisis, squats have numerically increased, and state policies are becoming more restrictive. As part of a broader trend, Italy is implementing "austerity" measures entailing extensive cuts in public expenditure (Cioce, 2015). These have impacted on public housing as well as sanitary services and centers that aim to protect women against patriarchal violence ${ }^{111}$. Currently, the movement and its national networks ${ }^{112}$ are fighting against a new decree, "Piano Casa," introduced in 2014 by Matteo Renzi's government. The latter does not endorse allocating sufficient money to resolve the housing emergency, introducing, instead, the possibility of privatizing and selling public unused buildings of different kinds (Cioce, 2015). Italian squatting movements have

109 More information about the many existing, can be found here: http://eipcp.net/transversal/0508/doucettehuber/it An example from Rome is that of "Lucha y Siesta", an occupied house devoted to women escaping violent relationships: https://luchaysiesta.wordpress.com/chisiamo-2/ (Last access on July 31 th 2016).

${ }^{110}$ In Florence, the movement was concretely established in 1990 and is the most widespread organization of its kind in the territory (Cioce, 2015). It does not have any political affiliation.

${ }^{111}$ More info on the closing of centres for women's help can be found here: http://ilmanifesto.info/romail-centro-antiviolenza-rischia-la-chiusura/. Info about the housing problem: http://espresso.repubblica.it/inchieste/2015/12/18/news/senza-casa-il-dramma-degli-sfratti-in-italia-sispecula-ma-aumenta-chi-non-ha-un-tetto-1.243938?ref=HRBZ-1 (Last access on July 31th 2016).

${ }^{112}$ Some "More Information" in Websites. 
particularly criticized Article 5, "Decreto Lupi," 113 within this set of laws. It addresses, without distinction, all illegal squatters ${ }^{114}$ and declares all gas, water, and electricity contracts signed by the occupants of a squat as illegal, while at the same time impeding them from registering with the municipality. Consequently, it denies people their constitutional rights such as voting, enrolling children in schools, and having access to sanitary services. In the case of irregular migrants, this extends further to their invisibility and "nonexistent" status (Cioce, 2014-2015) ${ }^{115}$.

The next chapter presents the stories of the migrant women squatters of Florence and their accounts of their alternative ways of restructuring love, along with traditional relationships, in relation to family unification.

\footnotetext{
${ }^{113}$ The article is the following: "Art. 5, Lotta all'occupazione abusiva di immobili. Chiunque occupa abusivamente un immobile senza titolo non può chiedere la residenza ne' l'allacciamento a pubblici servizi in relazione all'immobile medesimo e gli atti emessi in violazione di tale divieto sono nulli a tutti gli effetti di legge." (Art. 5, Fight against abusive occupations of properties. Anyone who illegally occupies a building, without entitlement, cannot ask for accommodation or connections to public services related to the same building. All the actions undertaken violating such ban are invalid to all legal purposes). (My translation from Italian). Critics about it can be found here: http://ilmanifesto.info/lupi-esquali-ecco-il-piano-casa/ (Last access on July 31th 2016).

${ }_{114}^{114}$ For example, it does not penalize differently squatters with criminal intent (Cioce, 2014-2015).

${ }^{115}$ Even the UNHCR (United Nations High Commissioner for Refugees) has expressed concern about the Italian issue, confirming the necessity of the existing mode of occupation for refugees, given the inadequacy of Italian policies. UNHCR goes even further, pointing to the increasing marginality and isolation that migrants are experiencing as a consequence of these legal changes (Cioce, 2015). More information at the following: http://www.refworld.org/pdfid/5003da882.pdf (Last access on July 31th 2016).
} 


\section{Chapter Three:}

\section{Hitchhiking within Hotel Madison, following women's stories}

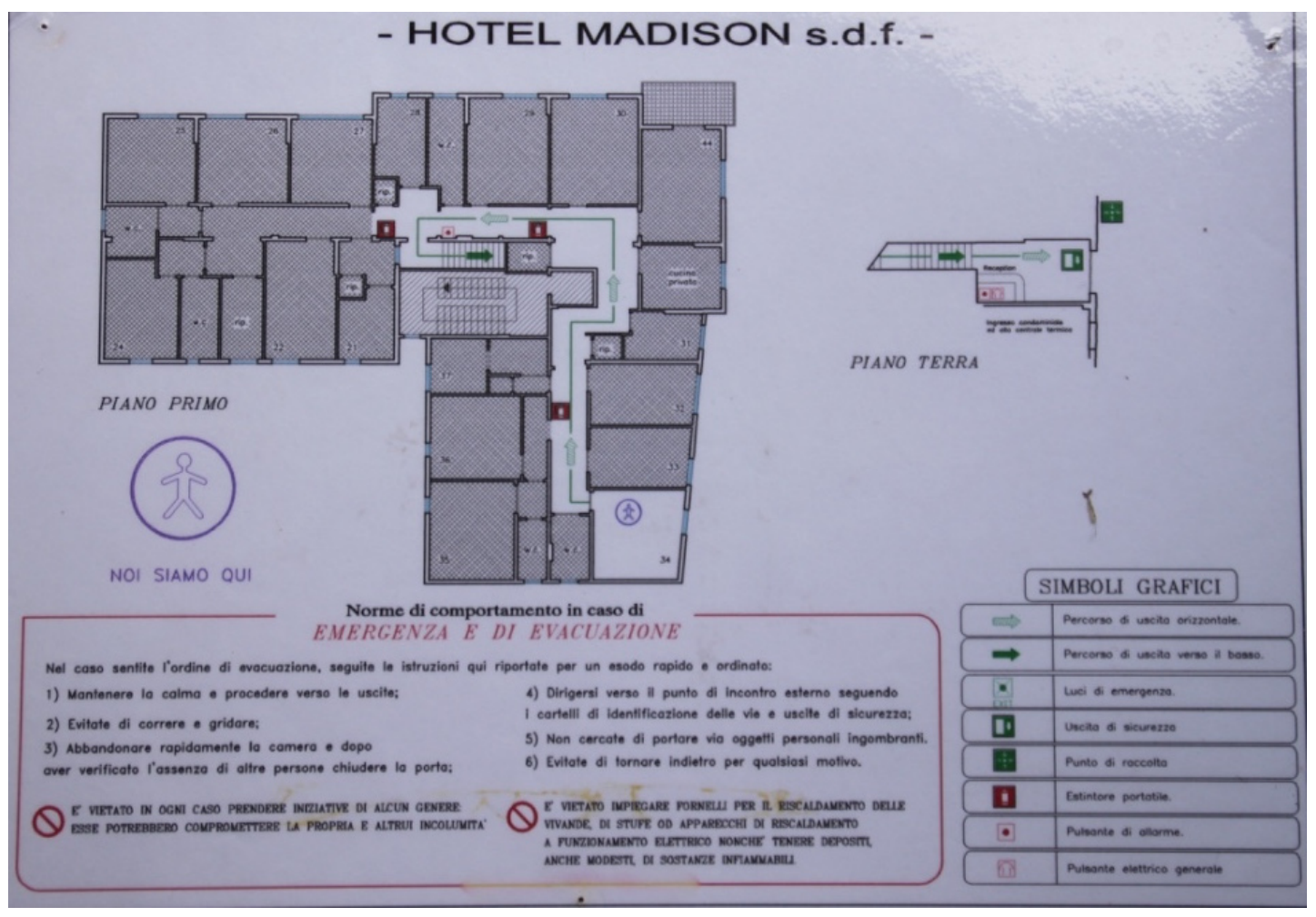

\section{Introduction}

I undertook this hitchhiking travel through the various rooms of the squat that was probably once a hotel known for quick and carnal manifestations of love. I like to think of my travel as genuine hitchhiking, because my directions did not follow any preestablished fixed plan or time. Every room was a country whose ruler was a woman; and every country had its own stories and myths about love. I followed the stories of whoever decided to pick me up, respectful of their rules, time, and wills. My itinerary and the "countries" where I was received are visually presented in this chapter using an unconventional architectural map that precedes every woman's story.

When I began my fieldwork, I was eager to hear stories about transnational love, seeking to avoid, at best, any kind of sedentary stereotyping, and ready to be surprised. 
But I was also prepared to find the same patterns of patriarchy that I myself have experienced and that I have encountered so many times before in others' love stories. Ultimately, both expectations were met.

My ideas on how to structure this chapter have changed over time. My initial idea was to divide the women's stories into two groups: women who began loving men in Italy and women who came from Morocco ${ }^{116}$ following love. The first group were, in my opinion, perhaps more interesting because of their still under-studied nature. As discussed in Chapter Two, the migration of women on their own is still regarded as a rare phenomenon (Al-Ali ${ }^{117}$, Andall, 2000; Anthias \& Lazaridis, 2000; Anthias, 2000; Bastia, 2009; Chell-Robinson, 2000; Gregorio Gil, 2000; Juliano, 2000, 2012; Lutz, 1997; Melchiori, 2000; Orsini-Jones \& Gattullo, 2000; Salih, 2001, 2003; Zontini, 2010; Zlotnik, 1995). This applies even more to Muslim women (Gandolfi, 2001; Salih, 2001, 2003; Zontini, 2010) ${ }^{118}$. The second group was evidently made up of women who came to Italy for "family reunification," as observed within migration studies. ${ }^{119}$ These women are the most studied group, and here love seems to be the excuse par excellence, at least for state bureaucracies that regulate migration, to sanction women's mobility (Lutz, 1997).

However, I soon realized that this dualistic division was neither representative nor respectful of the complexity of the women's emotive stories. Consequently, I opted for a wider partitioning of their interviews that was more coherently aligned with my findings, discussed in Chapter One, on the many forms taken by love and its opposite that we can call "un-love" - especially in the form of psychological and gender violence. $^{120}$

\footnotetext{
${ }^{116}$ All of the narrators of the stories are Moroccan women with the exception of one Romanian woman. ${ }^{117}$ See note 74

${ }^{118}$ Before conducting the actual fieldwork, I was interested in the question of how women who migrated alone met men in the context of emigration-who interestingly turned out to be mostly compatriots. I wanted to know which features of the encounter, of the courtship, and thus of the relationship, were different and new in a transnational context, compared to how they played out in the original context.

${ }^{119}$ Family reunification refers to the bureaucratic process that allows women legal access to the country and the right to stay after their husbands have acquired legal status in the migratory country, having applied for it in the context of migration (Anthias and Lazaridis, 2000; Chell Robinson, 2000; Lutz, 1997; Zlotnik, 1995). In Italy this process, which can last for years, requires the partner to fulfil detailed parameters, mostly regarding working conditions and their housing situations. Theoretically, family reunifications may also work in reverse, with legal migrant women able to apply for reunification with their husbands left behind in the native country. However, there is no widespread evidence of the latter. Women appear to mostly request reunification with their children when they are able to do so.

${ }^{120}$ Nonetheless, the choice behind the structuring of this chapter, and its consequent fragmentation into smaller sections was certainly not an easy one. Even though I am aware that sections do not represent any fixed boundary, I feel that they somehow limit the free flow of women's multiple voices and narratives.
} 
This travel into the women's history has the following coordinates. I begin by examining how traditional gender norms still strongly affect love relationships, especially in the transnational and squat context under study. I then proceed to highlight some cases of self-love, stories in which autonomous choices and will seem to prevail, no matter how embedded the women were in tradition and religiosity. The third section tells stories of physical violence. Psychological forms of violence are, sadly, components of each story of "bad love" (Bimbi, 2011; D'Odorico and Vianello, 2011). Moreover, such forms of violence are not at all recognized, either legally or culturally, in the MENA ${ }^{121}$ region (Salhi, 2013), and only to a very limited extent in Italy (De Gregorio, 2008; Lipperini \& Murgia, 2013). This is followed by a section about maternal love, which I deem to be a fundamental part of women's love. I present this section avoiding easy "essentialist" considerations attached to women that find their motivations in "nature" (Chodorow, 1974) ${ }^{122}$. The following section gathers the more relevant elements found during my travel that have to do with love, religiosity, gender roles, and technology.

Before sharing my journey, I would like to draw attention to some important aspects. First, all the stories presented here are cross-cut by different layers of analysis, and their reading essentially requires an intersectional lens (Collins, 1998; Crenshaw, 1991). Particularly in a transnational context, this means considering the roles played by precariousness, migrant masculinities, religion, xenophobia, and the economic crisis, among other factors, in women's mobility (Ahmed, 1999; Andall, 2000; Appadurai, 1996; Bhabha, 1994; Bilge, 2010; Bracke, 2008; Braidotti, 2008; Butler, 2008; Göle, 2010; Massey, 1994; Ponzanesi, 2014; Said, 1994; Scott, 2009; Treacher Kabesh, 2013a, 2013b; Walby, 2015).

Second, I am only presenting narratives here. As such, they do not themselves represent any established truth. On the contrary, they reflect a contingent performativity and other contextual variables (Haraway, 1988; Bhabha, 1994). Language does not represent, univocally and a priori, the objects about which it speaks. Rather, it builds a

\footnotetext{
In this regard, I am indebted to the theories of Braidotti and Butler for the concepts of performativity and fluid identities.

${ }^{121}$ Middle East and North Africa.

${ }^{122}$ I do not have a clear and firm personal positioning in this respect, even if I am thankful to the works of feminist theorists for unveiling motherhood as a cultural and social construction. Nonetheless, I do feel that without generalizing, the love a mother displays for her children is one that for now largely escapes any conceptualization that I myself am able to give it by the mere use of words.
} 
reality at the exact moment of the enunciation. ${ }^{123}$ Such considerations serve as a warning to me, as the investigator, and to the reader, to relentlessly problematize the concept of "truth."

Turning now to the linguistic aspects, I personally translated each interview, conducted in Italian, into English. In doing so, I have been unable to convey the women's linguistic competence in Italian, their hybrid and unique use of language ${ }^{124}$ and the gestures that accompanied their narratives, especially emotional expressions.

A final point is that the women's first names are used here. These are the names they wished to use on the occasion of our first meeting. ${ }^{125}$ As I have already noted, matters of strict "truth" in this regard are not pertinent to this kind of study.

\section{La famiglia è sempre la famiglia ${ }^{126}$ : The importance of tradition and the strength of patriarchal gender roles}

There are a number of reasons why I am beginning with the story of Nadia M. First, she caringly wanted to host me in her room during my first night in the squat. She was eager to tell me her story, lying in bed under the blankets, with her little daughter Marwa tucked between her legs. Moreover, her story shocked me. She was desperate, but, in spite of everything, not defeated. I felt that she was waiting for the moment when someone would show interest in her sorrow. As the investigator, my most difficult task in this particular case was to balance my positioning as a researcher with that of an empathetic friend (Alcázar Campos, 2011, 2014; Gregorio Gil, 2000; Grey, 2008; Kirsch, 2005; Preissle, 2006). While I feel that I wore the second hat better, feminist anthropology has taught me that objectivity and detachment are parameters invented by men (Abu-Lughod, 1986, 1990; Álcazar Campos, 2011, 2014; Gregorio Gil, 2000; 2011; 2012; Maher, 1989; Moore, 1988; Stacey, 1988; Stout, 2014).

\footnotetext{
${ }^{123}$ This kind of theorization, which has been described as a "linguistic turn," began in the seventies with Postmodernism. I am especially thankful to Professor Lola Sánchez for her exciting way of conveying insights on this theorization, from a feminist perspective, to Gemma's students.

${ }^{124}$ The language they use to communicate between them and with me is a blend of Italian and Arabic.

${ }^{125}$ Nadia seems to be a fashionable name in contemporary Morocco. The simultaneous presence of three Nadias resulted in my decision to differentiate the two adults as Nadia A. and Nadia M.

126 "Family is always family" derives from a famous Italian speech. This expression could be a crosslinguistic one.
} 


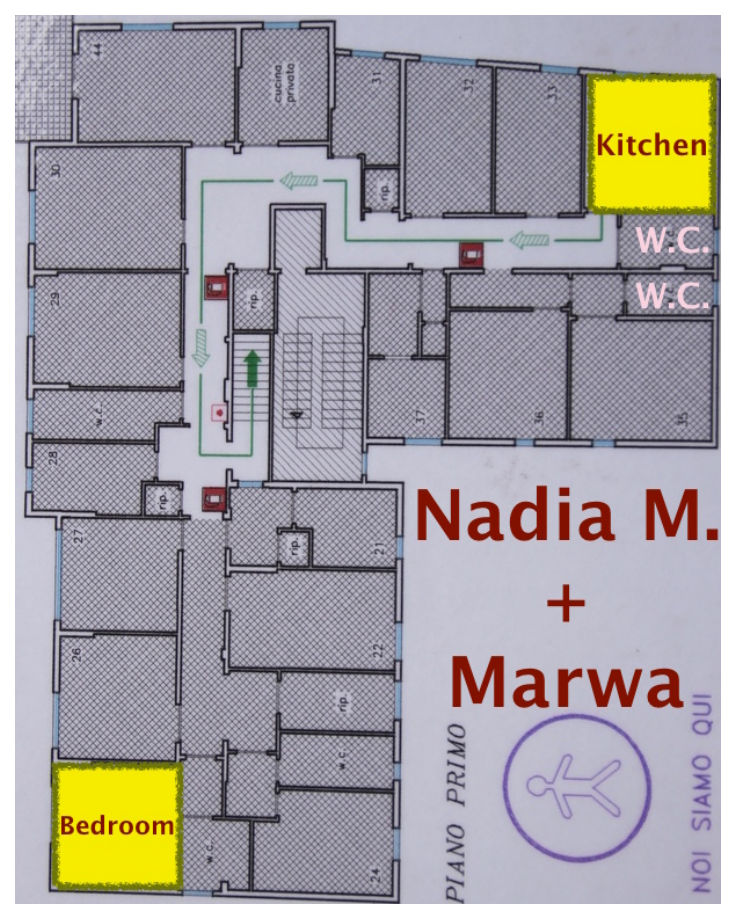

\section{Nadia M.}

Nadia M. is a 33-year old Moroccan woman. She is the mother of three children-two boys and one girl. Marwa, who is the oldest, is 10 years old and the only child currently with her in Italy. Both Ryan and Ayman - respectively 2 and 4 years old - are in Morocco with her mother-in-law. More than the tragic episodes involving her partner, it is the separation from her children that hurts her most. She speaks Italian, sometimes with difficulty, even though she has been living in the country for 6 years. Before she separated from her husband, he did not want her to work outside the home' just to "eat and have children," so she had few opportunities to properly learn Italian. Now, she says, "I know many things. It's no longer like before. I am more open."

As with the narration of almost with all the stories that I present here, she began by providing me, at best she could, with the bureaucratic details of her migration process. Nadia M. comes from Maarif in Casablanca. ${ }^{127}$ She has four sisters and four

\footnotetext{
${ }^{127}$ It is evident from the stories recounted in this thesis, as well from research on Florence's Moroccan community, as a whole, that perhaps the majority of Moroccan migrants come from Casablanca (Zontini, 2010). Even though Casablanca is Morocco's economic capital, its suburbs are clearly poor (Maher, 1989). The process of impoverishment of urban areas started with the industrialization and the extensive urban migration that followed. This also entailed a marked cultural clash, especially regarding women's roles in society (Maher, 1989; Mernissi, 1984).
} 
brothers. They all live in Morocco. Each of her sisters is married with children. Two of her brothers are single, one is married, and the other is going to get married for the second time. ${ }^{128}$ Her father died of diabetes when she was very young; her mother, who lives in a rented apartment, does not work outside the home. Consequently, the brothers fulfil the role of being their mother's main economic helpers. Nonetheless, Nadia M.'s migrant status, although based on an unquestioned ideal of well-being (Bartolomei, 2007), combined with her gendered role as caregiver, impels her to send gifts to her family whenever she can. ${ }^{129}$

Nadia M. got married in 2005 and Marwa was born the following year. She met her husband, Adil, at school when she was 14 years old. I asked her whether she chose her partner, and she replied that she did, but apparently "not well." Adil decided to migrate with the help of one of his brothers, who was already legally in Italy, thanks to his marriage to an Italian woman "just for the documents." ${ }^{, 130}$ Marwa was 3 months old when he migrated to Florence. During the first year, he returned twice to Morocco. $\mathrm{He}$ was adamant that he did not want Nadia M. to migrate. However, she insisted on this, and only succeeded in persuading him to apply for "family reunification" after 3 years. Two more years passed before she could finally join Adil. ${ }^{131}$

Nadia M. had been told by her husband that he was working in an iron factory in Florence. Just after her arrival, she discovered that he had been unemployed for 5 months. The situation was "a bit ugly," as she told me, unable, more than unwilling, to put into words her feelings about those bad times. After she arrived with Marwa, they began to live with Adil, his entire family, and other unknown people in a big squatted building close to his former workplace. However, to proceed with the regularization process, he officially paid a year and a half of rent for cheap accommodation in a village outside the city, which they had to visit once in a while for inspection purposes. ${ }^{132}$

\footnotetext{
${ }^{128}$ A similar pattern, revealing that more flexibility is accorded to sons than to daughters regarding the possibility and age of marriage, recurs in other stories (Mernissi, 1975, 1988; Maher, 1989).

${ }^{129}$ She especially sends goods such as coffee, chocolate, cheese, and clothes collected from the local Caritas offices. Caritas is a worldwide Catholic confederation that aims to help poor people. It has a strong presence in Italy.

130 Based on my interviews, this practice appears to have been extremely common a decade ago. However it is more difficult to sustain now because of stricter controls.

${ }^{131}$ This period of time is significant because it reveals the slow pace of bureaucratic processes relating to migration.

${ }^{132}$ Renting houses in remote, and almost inhabited small villages to become regularized, while squatting in the city is another phenomenon that emerged as a common practice. It must be stressed that real estate costs are prohibitive throughout Italy, with costs being especially high in Florence. This issue is the basis of the strength of the left-wing squat movement Movimento di Lotta per la Casa.
} 
Nadia M. described Adil's behavior upon her arrival when she found him unemployed as follows:

He started to go with many women... he kept telling me I had to go back to Morocco!

I always told him it was not possible, I did not have a home there.

It did not take longer for Nadia M. to discover that her husband had established a particularly close relationship with another Moroccan woman who got pregnant, and who "did not want to get an abortion." She discovered this extramarital relationship thanks to a female friend "who had been drinking" and finally confessed to Nadia M. Nadia M. decided to try to continue with her marriage, her reason having less to do with some vaguely articulated sentiment of "love" toward her husband, who had already insulted her, and more because of her perceived "duty" as good wife. Adil told her that there was "nothing" going on with the other woman, and that he was not going to marry her. So life went on for Nadia M., living in the squat with her husband, who was now working on an irregular basis, and his family. Nadia M. succeeded in playing the role of a good wife and mother: she got pregnant and bore two more children: Ayman, the eldest boy, and then Ryan.

The couple finally broke up when she was pregnant with Ryan. Forced to continue living in the squat with Adil's family, with Adil not helping with any parenting tasks (Maher, 1989:66), the police evicted them from the building when she was 7 months pregnant. She gave birth in a country house in Barberino del Mugello ${ }^{133}$, where the Italian girlfriend of her brother-in-law hosted and helped her. Her husband went visiting her only one month after Ryan's birth, "brought” by his mother. Nadia M. subsequently moved to a municipality building for migrants, subsisting on the meager amount that her mother-in-law could provide her.

Two months after Ryan's birth the situation became even worse. Adil had a serious car accident, and his lover at the time, seated on the passenger's side, was killed. He did not have a driving license. Another person in the other car, which was involved in the accident, was also killed. Nadia M. observed: "I guess he must go to the jail, I don't know..." He remained in a coma for 3 months and was operated upon. She noted, with a sad smile, "He is an invalid now. But he walks good and everything, you

\footnotetext{
${ }^{133}$ Barberino del Mugello is a town located $40 \mathrm{Km}$. from Florence.
} 
know..." She visited him regularly when he was at the hospital, even though he told her not to, but did not want to accept their legal separation, which Nadia M. wanted and finally got. "He kept telling me, 'and what do you think you will be able to do after? [i.e., without me]," says Nadia M.

Nadia M. met Adil's Moroccan girlfriend for the first time at the hospital. She had already given birth to Adil's child.

When she saw me she said 'sorry' and she hugged me...then when I went to the hospital...for me she's like my sister, I also brought along a sandwich for her, and we ate together there.

It seems that when some external event occurs, the relationship between unknown women, who are both caught up in the same trouble, strengthens their solidarity and, in her own words, their "sisterhood" (bell hooks, 1986).

Evaluating people's roles within situations is not always an easy task. It is definitely not so for women when it comes to articulating who is to be deemed "guilty" in such a complex situation entailing infidelity and disrespect toward a family as a whole. As Nadia M. states:

N.M.: In the end, it was not his [Adil] fault, but the women's fault... they knew he had a family!

Me: But do you think they knew that?

N.M.: Well...I don't know...but the one who died at his side, in the car accident I mean ...she called me twice because she wanted me to leave him! But this woman...he paid her. And then after I told him [Adil] to leave her, he told me, swearing on his mother ${ }^{134}$, that he would not go with her anymore.

Currently Nadia M. is working hard as the caregiver of a 91-year-old man. She hopes that her employer will be able to regularize her and allow her to live in his house along with Marwa. After some time, she would possibly be able to bring over her other young children, who are currently living in Morocco with her mother-in-law. Despite

\footnotetext{
${ }^{134}$ It is interesting to observe how swearing symbolically on the life of their mothers, who represent the supreme influence and most important person in men's lives, seems to be a transcultural feature, at least linguistically. It is unnecessary to elaborate on how this cultural construction is based on heteronormative patriarchy.
} 
her experiences, Nadia M. still cleans and cooks for her father-in-law on weekends since his wife is in Morocco with Nadia's children. This is despite working hard all week, cleaning, cooking, and performing childcare and other chores in the squat, as well as going twice daily to a far part of the city, using public transport, to accompany Marwa to school. She is exhausted but captive to what I perceive as blackmail based on her gendered role and the tricky separation from her sons. I had the impression that despite trusting in her mother-in-law's help, she fears that non-fulfilment of normative extended family "rules" on her part could cause an immediate breach with her motherin-law. The latter remains, however, her ex-husband's mother. In this particular case, without discounting the great help and solidarity her mother-in-law provides her, I suggest that a "nepotistic" kind of relationship, among women, highlighted by Maher (1989), is apparent.

Hanan, whose rebellion against normative gender roles is recounted further on, told me, regarding this situation, that Nadia M. felt she "must" be a "sharrala," or "la bonne" (caregiver). Hanan then added, looking at me: "Now you understand why I don't want to get married!"

Nadia M.'s story deserves careful analysis that considers many different aspects. These refer, chronologically, to the complexity of past and ongoing "affective facts" (Berlant, 2011:686) in her life; the roles of postcolonial masculinity and of women's solidarity; as well as the role of religion and its dogmas in her life. Starting with the factor of emotional complexity, the beginning of her relationship seems to have been motivated by sentiment, as she chose her partner and "loved" him. However, respect and understanding were not evident between the couple, at least during the last years of the marriage that she narrated to me. On the contrary, they indicated a total absence of the dimensions of love, and especially respect, during the transnational period of their relationship. Adil's masculinity, and consequently his normative gender role as the main family provider, was probably threatened in a "foreign" context in which he experienced perilous social and material conditions, combined with a certain degree of xenophobia (Boehm, 2011; Treacher Kabesh, 2013a, 2013b; Maher, 1989). It is important to stress that behaviors that include infidelity and lies, seem to follow a common pattern among migrant men: Arkiya's story, told by her daughters, and Suad's, to some extent, testify to this.

Treacher Kabesh (2013a) has described this male behavior in the postcolonial world as "the necessity of the other." She refers especially to men's need to hide their 
vulnerability. The only viable way of overcoming this obstacle is through the reinforcement of their stereotyped masculinity that constantly urges them to "conquer" women. Moreover, such stereotypic roles, are even more emphasized when men find themselves immersed in a society that is not sexually segregated such as that of Italy compared with that of Morocco (Davis and Davis, 1995; Mernissi, 1975; Kipnis, 2000). However, as discussed, Nadia M. repeatedly forgave his infidelities. This aspect could account for her persistence in performing her gendered duty and the economic necessity that bound her to him. ${ }^{135}$

However, women's solidarity intervenes to compensate for the lack of support of partners (bell hooks, 1986; Mernissi, 1988, Maher, 1989). Whatever "blood" relationship exists among women, their mutual assistance of each other is always more effective than the assistance provided by any institution or association. Examples of this are highlighted throughout the chapter. Given the Arab context, a change in the traditional relationships between wives and their mothers-in-law may be underway. As Mernissi notes:

In Muslim societies not only is the marital bond weakened and love for the wife discouraged, but his mother is the only woman a man is allowed to love at all, and this love is encouraged to take the form of life-long gratitude. (1975:135)

Mothers-in-law seem to represent the greatest obstacle to wives' decisions and to intimacy shared with their husbands (Mernissi, 1975; Mernissi, 1988; Maher, 1989). This "open war" is somehow contradictory as in most cases, mothers choose their sons' future wives. One could argue that migration poses a challenge to this cultural practice, or at least the experience as mothers both share impel mothers-in-law to be the first women to help other women, their daughters-in-law, and their grandchildren. In the specific case of Nadia $M$, the supportive role of her mother-in-law is undeniable: she cares for Nadia M's two sons in Morocco and persuaded Adil to visiting her after her third child was born. Nonetheless, as already discussed, Nadia M. does not openly trust this relationship and continues to perform some familial duties even though she is separated from her husband, cleaning and cooking for her father-in-law's. This fact

\footnotetext{
${ }^{135}$ Another field of possible inquiry that could be conducted would entail a transcultural investigation of women's motivations behind their forgiveness of their lovers' adultery.
} 
could possibly account for the persistence of the cultural traditional norms described above.

Regarding the role of religion in Nadia M's life, two concrete aspects require particular emphasis, as they could also play a determining part in the stories of other women narrated in this chapter. The first is Nadia M.'s practical approach to abortion, irrespective of its ideological ban within both Islamic law (Alamri, 2011; El Saadawi, 1991) and Moroccan society in general. ${ }^{136}$ A second aspect concerns the importance of alcohol in explaining the actions of Adil and others. Within the Islamic Moroccan community, alcohol is shown here to be a medium that facilitates communication in relation to social and cultural silences based on honor and shame. ${ }^{137}$ It is of relevance to these two topics to note here that Nadia M. was the only woman in the squat who wore the veil both in Italy as well as in Morocco. A common thread that connects almost all of the stories within this ethnography is the "instrumentality" of the practice of veiling. I will clarify this interesting concept further along in this chapter. Based on my personal field experience in many different Islamic countries, I must acknowledge that despite Nadia M. being considered the most religious woman in the squat, her practice of Islam did not signify scrupulous adherence to the religion's precepts. ${ }^{138}$

Nadia M.'s squatting story unfolded when she arrived at the squat via a friend who first hosted her and then moved away vacating the room. She lives in the most precarious section of the floor, without water and a bathroom close by. This part of the squat is also where Arkiya and her daughters, as well as Maria and two Nigerian women live. It smells of urine and is falling to pieces. A hierarchy exists within the squat, constituted into clearly governed spaces by stronger personalities and "seniority." Deemed unfair, this issue was highlighted by many of the women whom I interviewed individually. Nonetheless, Nadia M.'s room, where I slept, was incredibly clean. She

\footnotetext{
${ }^{136}$ In 2015 King Mohammed VI of Morocco considered initiating a discussion on the legalization of abortion. Still, it does seem to be a culturally stigmatized practice. More information can be found here: http://www.theguardian.com/global-development-professionals-network/2015/may/05/abortion-inmorocco-will-the-king-approve-a-progressive-law (Last access on July 31th 2016).

${ }^{137}$ Lila Abu-Lughod (1986) found that poetry was a medium through which Bedouin women could culturally express some of their unspeakable sentiments. The example that I am presenting is undoubtedly incomparable, given the different context and "acceptability" of the practices of poetry and alcohol use. However, alcohol does seem to offer another "medium" for transgressing boundaries of communication.

${ }^{138}$ To cite just one example without any intent of judging, I never observed her performing her five times daily prayers.
} 
received me after doing extra — and unnecessary — cleaning, in the spirit of the best Arab hospitality.

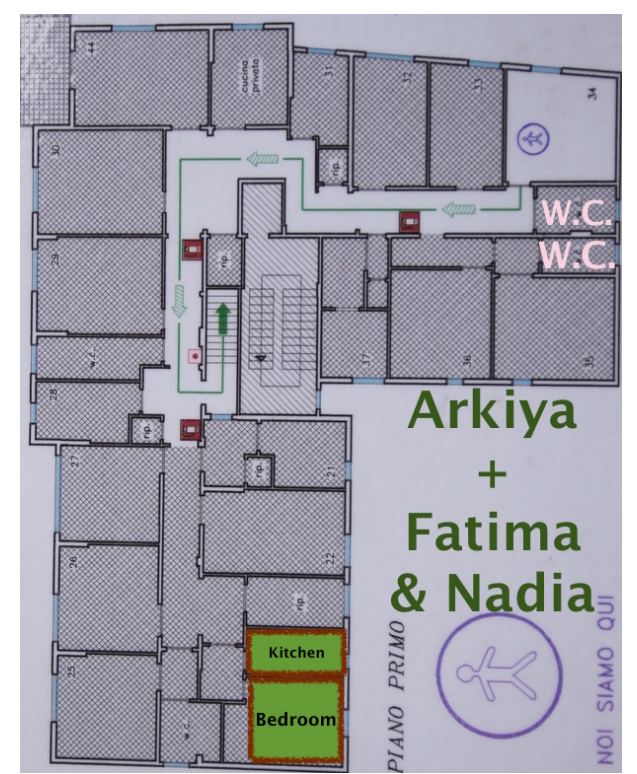

\section{Arkiya}

Arkiya's life seemed to have followed a similar pattern to that of Nadia M. She is a 35 year-old Berber from Agadir. She speaks neither proper Italian nor Moroccan, which makes her a sort of "outsider" within the squat. ${ }^{139}$ She had to struggle to reinvent her life, as did Nadia M. Her daughters, Nadia and Fatima, told me with typical children's frankness that after their parents' marriage in Morocco, their father "brought her [Arkiya] to Faenza ${ }^{140 "}$, at her insistence. Previously, he believed "she must stay in Morocco and him here." She did not work in Morocco, because this was his choice, not hers.

Fatima: He pretty much wanted to live a good life while mum had a bad one in Morocco...this is not fair...Dad ruled Mum's life too much. He always told her not to go out alone...to put on the veil! But now she no longer wears it.

Nadia: Well, in Morocco yes...

\footnotetext{
${ }^{139}$ She speaks Amazighe, the Berber language (Gandolfi, 2001; Montagne, 2000). Her linguistic difference also leads to culturally different practices (Maher, 1989) that are sometimes referred to in a denigrating way by other Moroccan women.

${ }^{140}$ Faenza is a city located north of Florence in the region of Emilia-Romagna.
} 
Fatima: Yes, but that is because in Morocco it is a bit embarrassing for them... for Moroccan people.

It is interesting to observe how they do not seem to consider themselves Moroccan ${ }^{141}$.

Nadia: He didn't let Mum work outside the home...but he didn't work very much, just a bit... and he earned little. So Mum wants her money too! Because when Dad earns something, he earns for himself...he doesn't buy many things for us... he thinks of himself, not of us. Sometimes he said to my Mum, 'I don't have enough money...go to Caritas!" and she said, 'If that is so I will go to work!' But he didn't want this...

Me: Why do you think he didn't want this?

Nadia: Because at that time women of our religion did not work...Moroccans let's say... Men didn't allow them to...I don't know why...only single women could work, not those with a husband.

Me: So your grandmother never worked?

Nadia: No, never...not even our aunts there... they just stay at home all day cleaning and cooking.

This Moroccan phenomenon finds anthropological support in Vanessa Maher's research (1989), which found that only free women "hurya" were allowed to work, along with women in rural areas.

After eight years of marriage the couple separated because they "disagreed about the rent and the money." Arkiya had to bring her daughters to Morocco, where her 18year-old son lived. He never went to Italy, because Arkiya's husband did not want him to. Searching for a job, downgrading from living in a social services building (strutture) to squats, she now works legally as a caregiver and both her daughters are in Italy, but not her son. However, she frequently returns to Morocco, because her mother is dying of cancer. In Morocco, her ex-husband's sisters help her the most.

Nadia: They are nice to us. Our uncles no, males not...my mum argued with them because they talk badly about her...they say, 'you escaped from home in Italy!'... They treat her badly.

\footnotetext{
${ }^{141}$ See Appendix Three for the young Berbers' interviews about love.
} 
In this case too, women's mutual help and "sisterhood," even if not biological are apparently of some importance.

Nadia: Now he [i.e. their father] is with someone else...because when Mum called him that lady answered and told her: "don't call anymore, he is my boyfriend!"

Me: Is she Italian?

Nadia: No, Romanian. He had some children I think...now everyone is separated" [she told me this without any sorrow, normalizing the widespread phenomenon of separation].

Me: Does your mum tell you about your dad?

Fatima: Yes, sometimes she talks to me...

Me: And what does she tell you?

Fatima: She is not sad...she doesn't care. Let's say...she cares, but...

Nadia: She doesn't suffer very much...she can also live on her own. She says, 'I must only work and then I can live on my own. Now that she works she can.

Fatima: It is not men who allow women to live... they can also live on their own. It's better to stay without a man ${ }^{142}$.

The highest value accorded to work, its sacredness, seems to constitute the cultural pride of Berbers (Gandolfi, 2001).

Aspects of Arkiya's love story, presented here, could be read applying similar categories to those used for Nadia M. First, her husband tried to prevent her reunification with him. Second, the constant dispute between the partners, which was economically motivated, centered on how money derived solely from the husband's income was to be spent, as Arkiya was not allowed to work outside of the home. The different uses made of family money by Arkiya and her husband accounts for how gender is connected to economy. Women are more likely to spend money on their children's necessities, like clothes and school requirements. Moreover, male partners, as revealed by the stories narrated throughout this chapter, seem to be mostly more ableand more willing - to engage again with other women. There are two main reasons for this. First, once separated, women mostly perform parenting tasks alone. They also have

\footnotetext{
${ }^{142}$ There is a popular Italian saying that plays: "I bambini sono la bocca della verità " (Children are the truth tellers). This undoubtedly has to do with children's minimal socialization into fixed gender norms, even if ancient popular wisdom clearly was not aware about gender.
} 
to focus their efforts on finding work. On the other hand, the social code of sexual modesty attached to women may represent an obstacle for them.

To conclude, I anticipate here that Arkiya, like the other women apart from Nadia M., only veil themselves in Morocco. This aspect that I describe here as the "performativity of veiling" finds in shame and strategy relating to the racist labor market in Italy its most important causes.

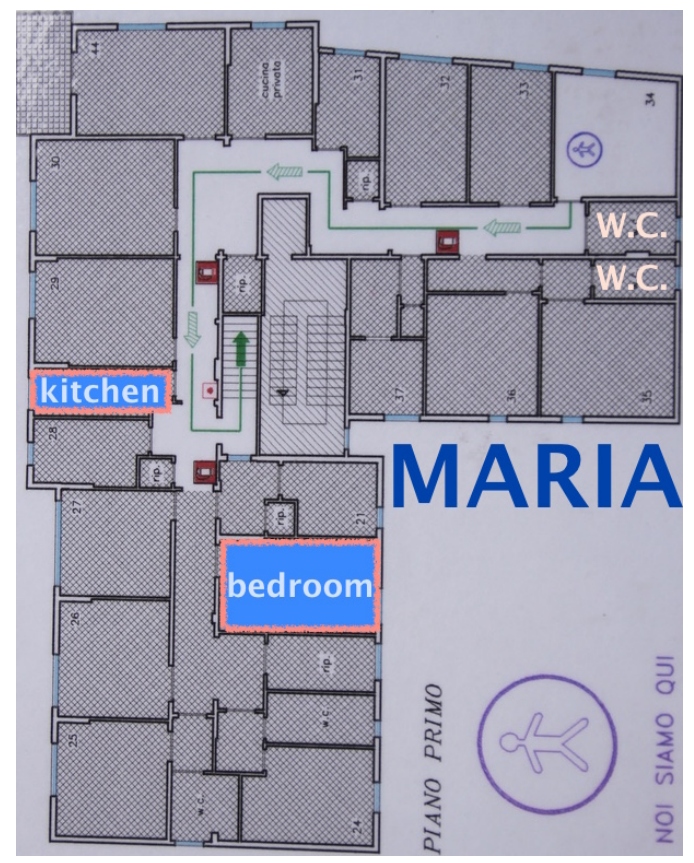

Maria

I had not previously met Maria before she bumped into me while I was talking with Nadia A. in the common area of the squat. She came to me afterward, bringing coffee and offering me some dark chocolate, her tearful and tired eyes testifying to her painful travel. She never asked me what my purpose was; she just sat at my side and started telling me her story, uninterrupted, in a trembling voice.

Maria is the only Christian in the group, and her faith pervades everything, helping her, I believe, to overcome the worst moments. It sustained her spiritually and materially through the work of the many religious associations in the area, which have 
provided her with a television, apart from food and other goods, which she refers to as "my companion." 143

Her story is significant as it sheds light on a less spoken kind of love, the one for family, with its strict norms of daughters' devotion that so often still constrains women from choosing their own life. In Maria's case, she lost her father when she was fifteen, and cared all her life for her sick mother in Romania. At the end of her narration, she made a gesture, indicating a big belly, while crying. Then she said: "My mother had a good life, an easy one. I am sixty-four and I am alone...I was wrong in my life.”

She managed all the aspects of daily life, arranging food, managing the house, while her brother squandered their father's heritage and built up debts.

He is irresponsible. He likes [doing things] carelessly...he likes women, cars, alcohol... He didn't came from the jungle. He had a big house...clean...that was our home before. He doesn't care for anything. He [only] cares for destroying. And I couldn't stand this...I came here to escape from this brother. I escaped from one hell, and ended up in another hell."

Maria was forced to migrate to Italy in 2011, after her mother finally died. Her brother did not even come to the funeral. "He has a bad heart," she told me. People lacking goodness of heart was a recurrent theme in her story, along with her reference to feeling something "with the heart." She was close to her sixties when she arrived in Italy at a time when the country was facing the worse period of the economic crisis. She has been unemployed for two years. She explains how she was fired from her last job as a caregiver of an elderly person:

He [her employer, who is the son of the old man] had problems with his wife... he was nervous. He told me: 'You are not happy, not cheerful', even if the house is clean. I told him, 'No, I am not happy.' 'So, you are free now, you can go!'

She does not speak good Italian. ${ }^{144}$ While trying to survive, she has had to face her brother's psychological threats, as he keeps telling people in Romania that she works in Italy but does not send any money. In reality, after losing the aforementioned job, she

\footnotetext{
${ }^{143}$ More than by the local Caritas, she is regularly helped by Comunità di Sant'Egidio.

${ }^{144}$ The apparent proximity between Italian and the Romanian language facilitated Maria's learning process in her late fifties.
} 
was forced to sleep, wrapped in cardboard, at the train station and inside a train coach when the cold worsened in the wintertime.

My heart was sad...[But] God typically makes light to help us...I am afraid of everything here. There are moments when I think it is God who brought me here to protect me.

Maria refers to the appearance of "angels," namely, volunteers working with the squatting movement, ${ }^{145}$ who offered her a room in an "only women's" squat. The theme of protection, embodied in a male person, often appears in her story. She refers to her brother as:

Someone who does not protect me...but he is a male!

And again:

I don't feel protected by my brother.

At the same time, contradicting herself without realizing it, she stated:

I would not stand a husband and I stand him ...no, I don't stand this"

She simultaneously refers to her strength and to her fragility:

I am strong. But for how long I don't know...I fear illnesses...psychic illnesses. I had a panic attack when they [the ticket inspectors] found me on the bus without a ticket. Palpitations...shame. I need people with warm words to give me courage [she said this while crying].

She then referred to her lack of communication with the other women, more because they did not share a common language than in relation to other kinds of more practical solidarity that she described. At the end of her story, always returning to the sorrow and

${ }^{145}$ Movimento di Lotta per la Casa 
difficulty that her brother caused her, she seemed to be alluding to her gender role of being a care provider and, somehow, a "mother" to her younger brother, when she said:

I did wrong. I have not been careful [stopping him from wasting everything].

To conclude, two aspects stand out in her emotional story. First, traditional attachments to the family and strict gender roles can even prevent women from establishing other kinds of relationships, including possible "love" ones. Moreover, Maria cannot see herself and her own role as the real "protector" of her brother, having cared for him and managed the family as a whole, while struggling with the gender norm that views men as the "real" protectors and carers. The fact that she cannot see how her normative gender role lies at the foundations of her "misfortune" impedes her from detaching from the psychological violence that her brother, even from a distance, inflicts on her.

\section{Self-Love... and more gender equality?}

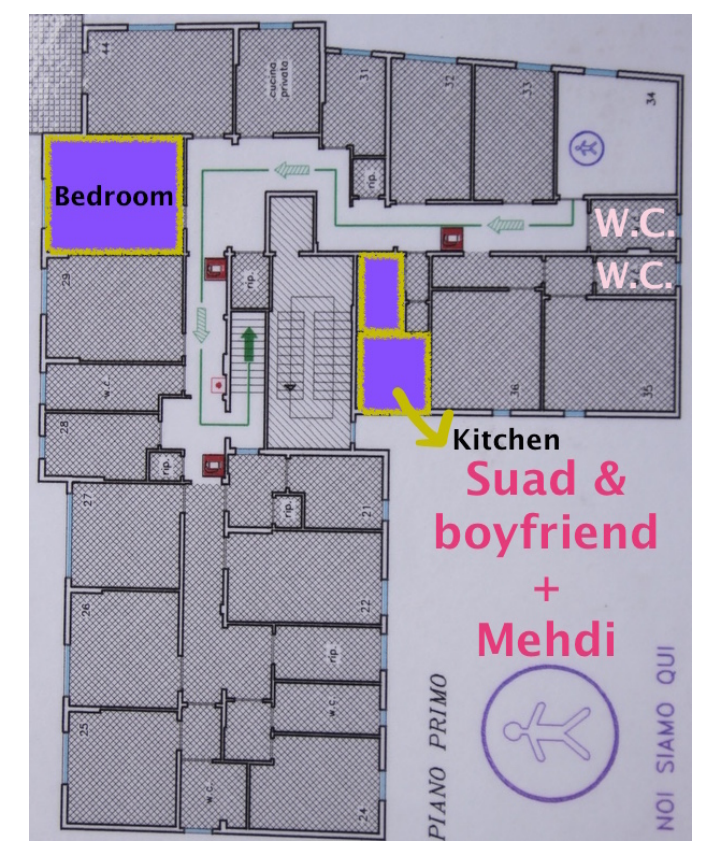

\section{Suad}

Suad began our meeting with one of her usual warm smiles. Despite her difficulty in walking, (due to some never spoken about disability), and despite being the mother of a 
4-month-old child, Mehdi, she always smiles from the heart, and her calm and strength make each of her life stories appear as simple and easy to overcome. Her positive manner, however, hides many of the difficulties that she has experienced during her life, both in Morocco as well as in Italy, caused by contexts of conservatism, economic precariousness, xenophobia, and gender discrimination that underlie all of the stories gathered together in this chapter.

We met in her well-kept and freshly painted purple room with basic but nice furniture. Anticipating my questions, she said: "I must be frank with you; for me it was not difficult." She was referring here to the process of her migration more than to her emotional past life. So I asked about her feelings, trying to deviate a little from the factual story she was starting to tell.

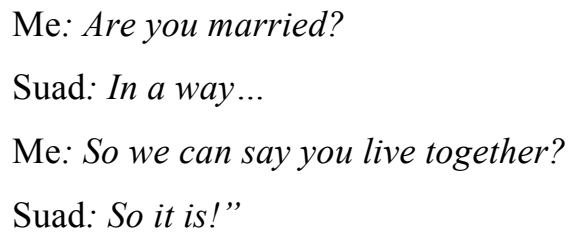

Suad arrived in 2009, assisted by her sister who was already in Italy. Her sister have married an Italian man, a friend of the family for whom she was working as an elderly member's caregiver, just to acquire legal documents.

She [her sister] stayed just once at home with him...earlier, regulations about marriage were different and easier. Afterword, she got divorced.

"Convenience marriages" are apparently a common strategy for facilitating the procurement of legal documents. This interestingly contradicts stereotypes concerning women, especially Muslims, who migrate alone. This kind of process grounded the difficult, and partly hidden, story of Khadija. Apparently, the love power is more compelling than the will to achieve a better economic life.

Suad studied to be a cook in Morocco. Once in Italy she managed to apply this specialization to a limited extent, but she actually worked mostly in the caregiving sector, without legal contracts. After some years, she met her current "boyfriend" (Il mio ragazzo, as she always called him, Italian style) at a friend's place. He found out more about her through the common friend and pursued her persistently for 4 months, 
asking her for a meeting, but she always refused. The motivations behind her refusal are unlikely to be found in some kind of modesty (traditional and religious) (Mahmood, 2001), but perhaps because she was fully living her independence following a long and unhappy story. But he "helped" her a lot during those months, when she was recovering from a car accident, and that was what finally convinced her. They are both Moroccan and aged 36. They are both without legal documents. Even though her partner has worked for 10 years, this has always been in the black market. Both had never previously been married. The latter circumstance is unusual in the context of Moroccan society (D'Odorico, 2014), ${ }^{146}$ as demonstrated, too, by the other Moroccan women interviewed for this study. They never went to Morocco together. She called her parents by phone and told them that she would like to marry.

Me: What did they answer?

Suad: Do what you think is right.

Suad wants to hold her marriage party there, but "all'italiana" (Italian-style), as she tells me laughing; over one day not seven!

Her current partner, the father of her son Mehdi, is the only man allowed to live in the squat. However, he spends most of his time outside, working as a black market bricklayer and customarily finishing his evenings at the bar with male companions. I asked Suad if the fact that she spends most of the time alone, even during the evening, hurts her, but she denied this. Men's tradition of spending their time late into the evening at the bar is an enduring one that, I would venture to add, is endorsed throughout the Arab world ${ }^{147}$.

He comes "home" just to sleep. He does not participate in any of the squat reunions and he does not take decisions, as Suad tells me with a smile. But his being "good" was what convinced her to be with him.

Currently she does not work outside her "home"; she is a full-time mother and a full-time squatter. She cooks and makes bread in the collective oven when it is her turn

\footnotetext{
${ }^{146}$ The author (2014:112) refers to the latest available Moroccan statistics (1994) regarding marriage, noting that socio-political changes have increased the number of nubile women above the average age of marriage, with many cases of illegal marriages to minors as the dates obtained for this study also corroborate. According to Moroccan law, 18 is the established age of consent.

${ }^{147}$ In the majority of Arab countries men at the bar drink tea. Alcohol is forbidden by religion and custom rules
} 
to use it. I asked her about laundry as there is no washing machine in the squat. Unlike other women in the squat, she washed almost everything by hand. So I asked her:

Me: Do you also clean your boyfriend's clothes?

Suad: No. Sometimes he takes everything to wash outside, including the child's, and sometimes he himself also washes.

This redistribution of home duties, however minor, seems significant in this context. The masculinity of Suad's boyfriend represents a challenging example as he accepts living in the "women's squat" as the only man, conscious that he cannot take any decision within it. Suad's relationship appears, then, to challenge some of the assumptions of normative heterosexual relationships, both in the overall Italian traditional context and in the Moroccan one.

Both countries still evidence a strong embedded traditionalism. The performance of some care-related duties on the woman's as well as the man's part, the consequent change of normative masculinity of Suad's partner, and the fact of having children outside of marriage are all elements representing a challenge to such traditionalism.

However, before making this choice, Suad was engaged for 4 years to a Moroccan football player, whom she defined more than once as a "serious" man. He asked her to marry him while they were both in Morocco, but she refused because he wanted to migrate to improve his life. She trusted him:

Suad: Go and see if you can change your life... and then we can marry, I told him. Maybe I made a mistake.

Me: In what sense? Do you think something could have been different if you had agreed to marry him in Morocco?

Suad: Maybe yes...

What followed could contradict her judgment of "seriousness" that she still accords to this man. His life in Italy as a male migrant reflects Nadia M.'s husband's experience in terms of carrying on other secret relationships in the emigration context, but with the intention of retaining the first relationship. This seems to be a common mode of escape from a highly segregated society, sexually, when encountering a Western and more "liberated" one (Davis \& Davis, 1995; Mernissi, 1975; Kipnis, 2000). It has to do with 
the primary role accorded to sexuality in both the Islamic tradition as well as in Arabic social practices (Mernissi, 1965, El-Feki, 2013; El-Saadawi, 1991).

When I arrived here [in Italy], his friends told me that he was with an Italian woman and that she was pregnant...Then he told me directly about it. But he said he didn't want her anymore, and he kept asking me to marry him...he was serious, he kept saying to his family: 'then I will go to Morocco and marry Suad anyway!'

Despite Suad's unconventional way of dealing with love - cohabitation, being an unmarried mother and not being married at the age of 36 years old - family still seems to be the most trusted source for verifying good intentions. If he kept telling his family about his love for Suad, this sentiment, Suad believed, must be genuine.

However, he is now with this Italian woman, and has three children. "Italian women like this color of skin," Suad tells me with a laugh. I asked her if they are married: "I don't know, I don't think so." Suad had to change her phone number three times because he kept calling her. While I had already begun to view this as stalking, she considers this to be normal. Going further in the story of her ex-boyfriend, she wanted to tell me, always laughing, about some behaviors that she perceives as being "very" Italian, and that contrast with the degree of "liberty" experienced by her current boyfriend, and to some extent by her, despite some limitations regarding her status as a full-time mother.

Now he cannot go anywhere without her going with him, the Italian woman I mean...he cannot even go visiting his own parents in Firenze without her always being with him...So now he is learning a lesson! This way of doing is very Italian.

To sum up, Suad's love story represents a unique case concerning normative heterosexual gender rules in terms of marriage, parenting practice, age of the couple, care-work, and the control each partner has over the other. 


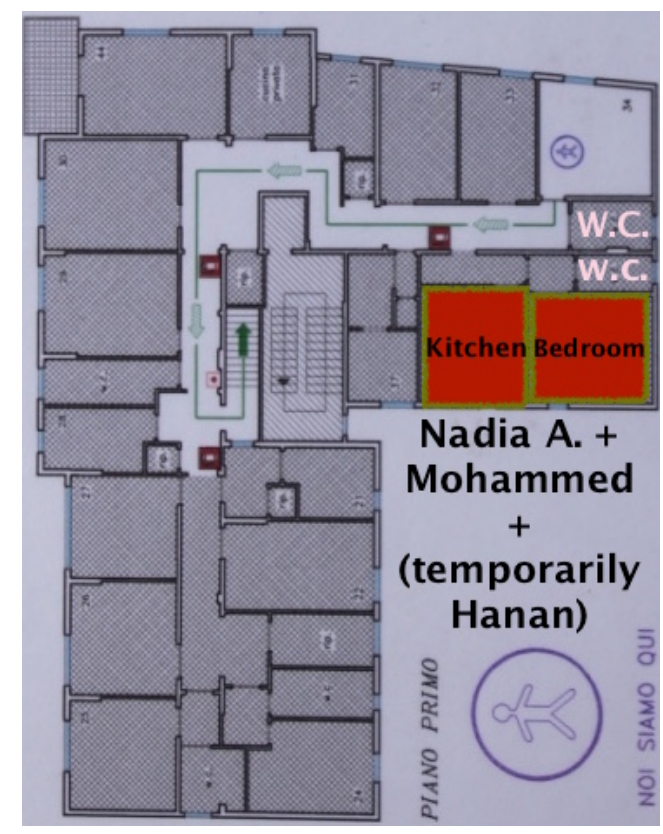

\section{Hanan}

Hanan is Nadia A.'s friend ${ }^{148}$. She is not actually a resident squatter, but was living there throughout the period during which I conducted my fieldwork. She was working as a caregiver of an elderly woman, and suddenly found herself both unemployed and homeless after her employer died. Consequently, she went through the typical life pattern experienced by women involved in what sociologist Arlie Russell Hochschild calls the "care-chain." 149

The degree of Hanan's self-esteem and independence that $I$ view as "empowerment" from a feminist perspective interested me very much. Our talk was the most informal one that occurred during my fieldwork. Maybe for this reason, she freely expressed her judgments, as in a typical chat — and to some extent gossip — between Arab women, One of these women was myself, seated on a typical Arabic sofa, with the television tuned to a Moroccan music channel, and the other, Hanan, washing a pile of sardines to make dinner for some male "friends."

\footnotetext{
${ }^{148}$ Hanan refers to Nadia A, as "Uhti aziza" (literally, "my beloved sister"). As noted by Maher (1989), the reference to friends as "sisters" is common among Moroccan women who have established what the author calls a "female net," which precisely matches what bell hooks prefers to call "sisterhood."

${ }^{149}$ See Hochschild and Ehrenreich (2003), Global Woman: Nannies, Maids, and Sex Workers in the New Economy. Hochschild is also known for her theorization of "emotion labour."
} 
Here, I must stress two points. The first, and most important, is that I observed, more than once, the "instrumental" use that some of the women made of their gender role to acquire benefits for themselves. As Nadia A. told me, because the wives of some Moroccan friends were back in Morocco, and these poverini miskiin (poor people) ${ }^{150}$ are unable to cook for themselves and are tired after work, they prepare a proper Moroccan dinner for them in exchange for food and money. Those friends even help them to carry home heavy bags full of food from the halal local shop. But, as Nadia A. told me, "they don't sleep at my place! Then they go home."

The second point refers to the fact that Hanan worked in a restaurant in Greece, her first country of migration. Before that, she said she was unable to do anything in the kitchen. This may sound somewhat contradictory to women's normative and gendered socialization.

I have been present both during the lengthy preparation of such dinners and during some of the interactions between Nadia A. and Hanan with these men. This happened twice during my stay. On both occasions, I had dinner with the children in another room. As a participant observer, I was struck by the degree of joking, laughing, and especially flirting between them during these interactions. As revealed by a number of novels, ${ }^{151}$ oral traditions, photographs, ${ }^{152}$ and books, the Western investigator must always bear in mind the level of eroticism present in Muslim male-female interactions, especially when carried out between a married and, therefore, "licit" couple (El Feki, 2013; Mernissi, 1975, 2000), but also in other contexts such as my research setting. Such episodes represent the extreme end of the "freedom" spectrum evidenced in interactions between "free" women who are empowered and self-sufficient in a foreign and, therefore, non-segregated context, with married men in their home. In this case, one, Nadia A. was divorced, ${ }^{153}$ and the other, as I will explain further, was determined not to marry ${ }^{154}$.

\footnotetext{
${ }^{150}$ It is interesting to note the linguistic and cultural meanings shared by the same word "poor" in both Italian (poverini) and Arabic (miskiin), which connote pity.

${ }^{151}$ One of these is the renowned "A thousand and one nights." While the collection was written from the tenth century onward, the origin and exact location of its development are still not precisely known.

${ }^{152}$ An interesting example can be found in the project "Secret Life of Syrian Lingerie: Intimacy and Design" by Malu Halas and Rana Salam (2008; Chronicle Books).

${ }^{153}$ Divorce seems to feature prominently in the lives of both rural as well as urban women, as Maher's (1989) anthropological inquiry reveals.

${ }^{154}$ For Mernissi (1975), men's incapacity to control the erotic power of women lies at the basis of the sexual segregation of public and private spaces in the Muslim world. This regards also the veiling practice, which grounds have to be found in the Islamic rule, but women's practices and signification of it
} 
Hanan and I started our conversation in the middle of a "love" discussion about the divorces of Nadia M. and Nadia A. ${ }^{155}$ So I asked Hanan:

Me: And you, don't you want to marry?

Hanan: I don't like jail.

Hanan is 30 years old and has had a boyfriend in Morocco for the last 3 years. After divorcing one woman, a lawyer, her father married two women, polygamously. ${ }^{156}$ Before her marriage, her mother worked outside the home. Her father normally stayed one day, alternately, with each of his wives.

He works on a farm. This is not a bad work in Morocco...He has a car and three houses... Yes, he lives a much better life than me here!

I asked her about the relationships she had with her mother and the other wives - both the divorced one and the second wife in the polygamous marriage.

Hanan: They are good.

Me: Isn't your mother jealous?

Suad: I don't know if there is something that she hides...but I think that for her, this is a normal thing...before in Morocco, it was very common! Not now...now [for a man] my wife is only mine. My grandfather too was polygamous.

This testifies to the wide and relatively recent diffusion of the practice of polygamy in modern Morocco, given Hanan's young age. Moreover, it is corroborated by the

\footnotetext{
have varied according to the historical period, the geo-political situation, the different degrees of women's desire to wear it, as well as different degrees to which men have imposed it.

${ }^{155}$ Funnily, when we began our conversation, an advertisement of a new Moroccan movie entitled "Insoumise" (a French word for "un-subjugated" referring to a woman) was being broadcast on television, "Insoumise" (by Jawad Rhalib, Morocco-Belgium, 2016). It tells the story of a young Moroccan unemployed woman who migrates to Belgium where she discovers the unfair situation of migrants employed to carry out seasonal agricultural jobs.

${ }^{156}$ In the Moudawana, which is the latest Moroccan personal status code, polygamy has been not outlawed, but concrete measures have been introduced, making it more difficult (Foffano, 2007).
} 
testimonies of the other women. This accords with older historical and anthropological studies (see Mernissi, 1975, 1988; Maher, 1989). ${ }^{157}$

Using Maher's (1989) terminology, "complicity" among Arab women could account for the lack of jealousy and apparent rivalry between Hanan's mother and the other wife. Moreover, Hanan's statement implies a strong sense of "possession" and, therefore, jealousy that men feel towards women, within monogamous marriages. However, her contextual emphasis is not in itself sufficient to allow for any firm conclusion about her value judgments concerning the differences between monogamous and polygamous marriages.

The lives of Hanan and her sister exemplify a strong challenge to tradition and stereotypes, especially given the context of their origin. She told me that one of her sisters, who is 37 years old and lives in Belgium, is "like her."

She thinks like me. I make money, I buy a house for myself alone in Morocco, a car... and that's it!

The other sister, who is 35 years old and lives in Morocco, is also single.

Hanan decided to migrate alone. She found out through an online search that a girl she knew was in Greece, so taking advantage of this contact, she migrated to Greece. When she arrived there, she found that this friend was living with a Syrian man. She does not know what their actual relationship was, married or just engaged, and she does not seem to care, showing a considerable degree of flexibility concerning the formalizing of relationships. What is of note, however, was her disappointment relating to the control this man exerted over her friend.

In Greece she worked in a hotel and was happy before the situation deteriorated to the point that compelled her further migration to Italy.

Greek people are better than people here...Here, I don't want to generalize, but they [Italians] are a bit racist. When they hear you are a Muslim, they don't give you a job.

\footnotetext{
${ }^{157}$ El-Saadawi (1977) and Mernissi (1975) provide a more in depth theoretical and religious background to the practice of polygamy.
} 
There are two considerations here. First, Hanan does not wear the veil, which signifies a woman's immediate and visible "categorization" as a Muslim, when seeking a job. Second, this a priori "categorization" extends even further (Zontini, 2010), as many stories from my fieldwork attest. In fact, at some kinds of job interviews in Italy that I conjecture would apply to the kinds of work that migrants would do, such as the care economy, a common question, which violates the Constitution, is whether the applicant is a Muslim. ${ }^{158}$

Following Hanan's story, I asked her about her expectations regarding her 3-yearlong engagement to her Moroccan boyfriend. She told me that he often comes to Europe for work with a "Schengen" visa. He is a 38-year-old divorcee. He has asked her to marry him, but she refused.

Me: Don't your parents want you to marry?

Hanan: My mum yes...she tells me she wants grandsons.

Me: And what is your father's opinion?

Hanan: Nothing...because I have my life and it is only mine. I am a free woman, that's what I always tell him. For this reason I am here...

Me: Apart from marriage ... would you like to have children?

Hanan: Do you want the truth? No. I don't want [children]. Life is hard...Look at Nadia [Nadia A.]! And the other Nadia [Nadia M.] too... They suffer for their children. I am alone.

Me: Does your boyfriend have children of his own?

Hanan: I think one... but I am not sure, I never asked him about it.

Me: How come you never asked?

Hanan: It is not a sure thing between us...I won't ask him till I am sure.

These statements reveal the "normalcy" of men getting married and divorced more than once, and consequently having many children. Moreover, they reveal that Hanan's evaluation of her relationship with her boyfriend is that it hinges on his behavior toward her and not on his past.

When her boyfriend comes to Italy, he stays at a hotel in Milan and pays for her train ticket so that she can visit him. "But he comes to Italy just for work...not for me!" she says. Moreover, she is not happy with this way of carrying on the relationship:

158 Costituzione Italiana, art.3 https:/www.senato.it/1025? sezione=118\&articolo numero articolo=3 (Last access on July 31 th 2016). 
It takes time to go there by train...five, six hours...I have my own things to do.

To sum up Hanan's approach to love, it is mainly focused on self-love that is reflected in independence and reluctance to make the inevitable compromise and experience the power disequilibrium that a love relationship necessarily entails. Like Nadia A., her flirtatious interactions with some men, and the way she manages her engagement at a distance, reveal her relaxed attitude toward moral judgements and normative behavior.

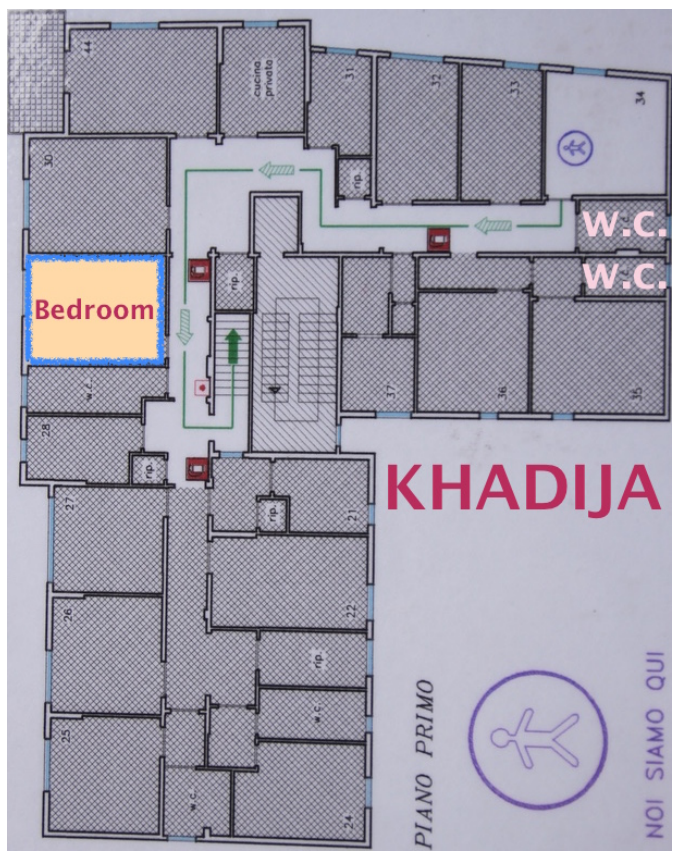

Khadija

Khadija has a very interesting past; one rich in elements that reveal in depth insights into women's migration and rebellion, precariousness, religion, and sexism that manifest in stereotypes against women within the Arab world itself. She is 45 years old and comes from El Kelaa des Sraghna. ${ }^{159}$ Her father is the local Imam, and her mother works at home as a seamstress. She got married to a cousin - a common practice in the Islamic tradition (Mernissi, 1988; Maher, 1989)—when she was 16 and he was 20. In response to the question of whether she loved him, she said, "The family wanted it... all

\footnotetext{
${ }^{159}$ This town is located almost $70 \mathrm{~km}$ from Marrakech; It is mostly dependent on agricultural production.
} 
Moroccans, all Arabs do so!" When she was 18, she began working in a factory and stayed there for 3 years. "But they paid me little and I wanted a life," she told me. Then, she decided to divorce him and start her own life.

Me: Weren't you happy in your married life?

Khadija: Yes, I was happy but you know...I was a girl who didn't know anything.

So I divorced.

Both partners wanted to divorce, so they went to request it and obtained it quickly. Then, on June 18, 1991 she courageously migrated to Libya, arriving by bus in Tripoli 3 days later. She was the first, among all of the people she knew, to migrate alone. After a week she found work as waitress in the hotel where she was residing. The woman who shared the room with her initially suggested that she go looking for a husband, but she replied "she hadn't come for that." Given her determination, the woman recommended her to the hotel's owner.

The owner asked me: 'Where are you from?' 'I come from Morocco' I told him. And he said, 'Moroccan people are all sly'...I couldn't say anything, I needed a job...but then after 3 days of an unpaid trial, I immediately took that job.

Then she found a room with a "good" Moroccan family and stayed there until she married again. Her second husband was her employer's son.

Khadija: One day at work he asked me, 'Do you want us to go have a coffee somewhere else?' I told him 'okay.' I thought he wanted to talk about work. 'I'll take you there by car,' he told me. I said to him, 'tell me where we should meet. I will take the bus. I can't come by car with you.' We met at a café and he wanted to invite me. He told me 'I want you to be my girlfriend.'

Me: Did he tell you that the first time you met?

Khadija: Yes. And I told him, 'Shame on you! You're an Arab!'

Me: Why?

Khadija: Why? Because Arabs are not like that, you know...not like here...you stay engaged for 2 to 3 years...not that you have children, after you marry...no, Arabs are not like that. Before getting engaged you talk about it, you don't go to bed directly... 


\section{Me: What did he want?}

Khadija: What does being his girlfriend mean in Arab society? That you go to bed with him... It's not [be my' girlfriend and then I marry you. Seriously, for Arabs, it is shameful ${ }^{160}$...I told him I couldn't and I went back to work. I thought that if I became his girlfriend, he would tell me to stop working. Two days later, he asked me out to lunch. I told him, 'okay, but just as friends.' At the restaurant he was wearing two wedding rings. I asked him what his family had to say and he answered, 'She is a good girl who works.' So I agreed... after 2 months we got married. But I told him, 'Listen, I will marry you...but I will not leave my work...my family, they are poor. ${ }^{161}$ They don't have anything. I came here for work, not for getting married!' He told me not to worry; both of us were going to work. And it was like that. Then he also helped me with a bit of money and I was able to buy a house in Morocco.

From this first story, we can immediately recognize Khadija's determination and intention to be and remain economically independent, and the role of her partner in materially providing her with money as being a highly valued one. The topic of not having a home or property back in Morocco is a recurrent one in the women's stories. Moreover, women's ability to buy a property by themselves to maintain their roots is undoubtedly considered a great achievement. Furthermore, die-hard stereotypes are attached to Moroccans within the Arab world. The sexist stereotypes, in particular, finally determined Khadija's marriage destiny after 6 years. Despite her partner being supportive, as well as her mother-in-law, who allowed her to continue working when their daughter was still young-following the recurrent pattern of women's mutual support in these stories - her father-in-law treated her badly because she was Moroccan.

He was bad. He thought all Moroccan women were bitches. He said to my husband, 'You can't stay with that 'stranger'.162

It is interesting how boundaries of "strangeness" and stereotypes are also connected within the Arab world itself and not just in encounters between the West and "the rest"

\footnotetext{
${ }^{160}$ Hchouma. See note 50.

${ }^{161}$ See note 150 .

${ }^{162}$ Siher is an Arabic word that Moroccan use to denigrate prostitutes. Her father-in-law used it to denigrate all Moroccan women.
} 
(Hall, 2006). As Tahar Ben Jelloun ${ }^{163}$ has famously stated: "We are always someone else's stranger."

Her mother-in-law was nice to her, but she feared her husband. "It's not like here in Italy ... she couldn't say anything against him." So she finally got divorced, even though her husband was "very good." She then began her third adventure: migration to Italy.

She arrived in Italy in 2008 and after working for a year as a caregiver, she met a 37-year-old Italian man, one of her cousin's friends, whom she eventually married. After one year of marriage she discovered that he was a cocaine addict who spent all of their household money on drugs. She is currently seeking a lawyer who can help her manage the problems that arose after she left him. She does not have a residence permit, and contrary to Khadija's account, her husband told the inspector that he had not seen her for a very long time.

Some aspects of this marriage, such as the different versions of Khadija and her partner given to the inspector, could suggest that she married to acquire legality. As a feminist and researcher, it is neither my desire nor my purpose to attempt to locate the boundaries between "true" and a "false" love. Who, in fact, has the authority as to determine whether those boundaries even exist "out there" or whether they are constructed within each story of love merely as a contextual and contingent mix of personal expectations, conveniences, and sentiments?

On the contrary, this story could open up insightful reflections on the role that love plays as the supreme justification for women's migration that has more legal power than any individual's will and desires to improve her/his life and achieve an independence that is not just economic. Moreover, it is remarkable that even in the context of an encounter motivated by academic research, "gossip" played a role in the interactions between my subjects and myself (Dreby, 2009). Such gossips regards Khadija's "white lie" concerning her third marriage, leading me to become aware of a parallel relationship she seems to be having with a Moroccan man. This element serves to corroborate my assumption of the prevalence of meetings between compatriots even in an emigration context: Moroccan women seem to prefer Moroccan men.

Next, I will present Khadija's unfortunate union with the Italian man in her own words.

\footnotetext{
${ }^{163}$ Tahar Ben Jelloun is a Moroccan writer.
} 
Khadija: Before he was handsome, thin...now look...he can't pass through that door... his face...so swollen! I told him 'stop that thing!' But he answered 'I can 't...I can't give you my money...I can't stay with you!'

Me: Did he ever threaten you in any way? Did he become violent taking drugs?

Khadija: Once I told him not to do this in my house. 'If you really want, go do it somewhere else!' So he went to the wardrobe and threw out all my stuff. He told me: 'take all your stuff and go away!' I left, sleeping at a friend's place and then the following day I went back and he told me, 'I don't want an owner.' I replied: 'I am not your owner, just stop with this drug!'... This is a bad story, really... Bad and hard.

Me: Were you in love with him when you got married?

Khadija: Yes, but then I discovered that he was taking drugs...

Me: But what did you like about him?

Khadija: During those 6 months when we went out before marrying, he was good...calm, we laughed, joked, had fun ... went to cafeterias, restaurants...

Me: Who normally paid?

Khadija: One time him, one time me...but then I discovered...and I didn't leave him, I stayed at his side.

Me: Why didn't you leave him when you discovered the he was on drugs?

Khadija: Before, I was in love...I really liked him. I thought yes, little by little, I will stay with him...he is going to stop that thing. Once I told him to go to the doctor, but he said 'Are you kidding? I can't. He will look at me and say I am a drug addict.'

Me: Did he feel ashamed of being a drug addict?

Khadija: Yes...

Me: So when you discovered that, wasn't he kind to you anymore?

Khadija: No, he was nervous...Then after he took drugs he once again became the man I knew, calm, good... Oh my God, when there wasn't that thing...all the windows of the house broken...

Me: Violent?

Khadija: Yes...

Me: Did you ever feel threatened by him?

Khadija: No... well, once. I went to emergency...but just once...

Me: Did he beat you?

Khadija: "No!...no, no...never!

Me: So why were you afraid? 
Khadija: He hit all the doors, the things inside the house...the walls...I thought: why am I so unlucky in my life? First marriage not lucky, second marriage not lucky, now my third marriage like this...

Me: Who pays the rent for the house?

Khadija: Before, both of us paid together, even the bills. Now he doesn't pay any bills, just the rent, otherwise where would he take this drug? At mum's and dad's place? One month ago I went there and I found that there was no gas...I asked him: 'Why is there no gas?' He said there is a bill of 450 euros to pay. I told him 'Give it to me. I will go and talk to them, see if we can pay one month to start...' He said: 'No, they want all the money now!' So I said okay. I gave him all the money and then I went there last week and there was no gas again! I asked him: "Why is there no gas?" And he said he paid but they didn't reactivate it. Then, I understood that he had spent all my money on drugs. So there is no gas there. How can I live there? How can I stay with him? I can't. Really, I can't anymore. This is a bad story.

Me: Does he sell drug illegally too?

Khadija: No! He fixes computers.

Me: Would you be able to testify that drugs were the problem in your divorce case? Khadija: Sure! Even tomorrow! When I went to the central police station they asked me why I was not with him anymore.

Me: Did you tell them?

Khadija: No...because I felt something...I felt I didn't want to harm him...Do you understand?

Me: Well, I can understand. He's your husband.

Khadija: That's it...I can't go and tell the police he's a drug addict. I don't fear for me, they can do exams...cigarettes yes, but other things no! Yes, I am Moroccan, I know I am Moroccan.

Me: Does that matter?

Khadija: Yes, they think that Moroccan people do this and that...cigarettes yes, but nothing else! He is the one who's the drug addict.

Even if some would like to think of this story in binary terms such as a marriage "for interest" and not "for love," what is both interesting and terrible is how Khadija found herself trapped in a tricky situation in which her options, as an illegal resident, were very few. In reality, marrying an Italian man did not even benefit her legally, because she found herself in a position of losing a lot of her money to cover his debts, putting 
her, on the one hand in a position of fear of his nervous aggressiveness when he did not take drugs, and on the other hand, subject to stereotypes that immediately linked her, as a Moroccan, to drugs matters.

\section{Violence}

Each story of "un-love" presented in this chapter finds its common denominator in violence. Each woman was exposed to some kind of psychological violence carried out by husbands aimed at undermining their wives' self-esteem (the cases of Nadia M. and Arkiya), sometimes even inflicted by other men within patriarchal families, if not by the husband himself (Khadija's story). In this section, however, I will briefly present two testimonies of physical violence, one described by Nadia A. and the other from Arkiya's past, as told to me by her daughters. In telling the latter story the daughters linguistically concealed their mother's identity to a certain degree, using expressions such as: "It happened to a woman...not my mother! Another..." Even if we cannot be certain that Arkiya herself experienced the violence, the story is anyway representative of one of many nameless women who suffer patriarchal violence on a daily basis.

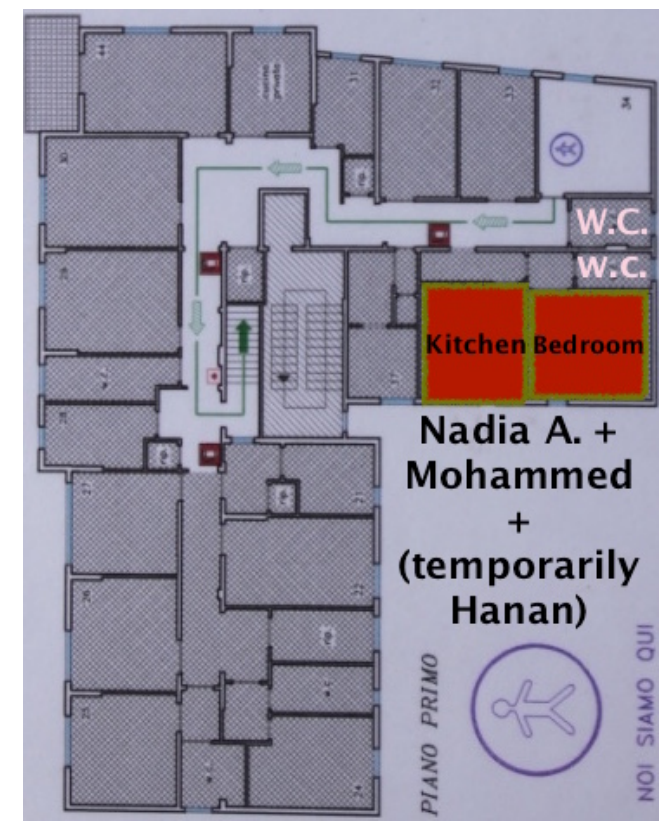




\section{Nadia A.}

Nadia A.'s personality is one of the strongest in the squat. She is one of the original squatters. I kept in touch with her to organize my fieldwork. She actively participates in squat demonstrations and meetings. She is, in her words, "half Italian and half Moroccan," having lived exactly half her life (15 years) in Morocco and the remaining half in Italy, where she migrated with her father and siblings. She conveyed her story to me, and chatted with her friends in an interesting linguistic mix of Italian, Moroccan, and Tuscan slang. She met her Moroccan husband in Prato, a textile city close to Florence. She worked there legally in a factory and lived with her husband in a rented house where they started a family with the birth of Mohammed. ${ }^{164}$ She is the only one in the squat to have "that paper that finally says 'divorced'!" as she emphatically told me the first time I met her. Undoubtedly her motivations for asking for divorce lie in her husband's physical violence.

The violence argument appeared all of a sudden while talking about her son's problems. ${ }^{165}$ My ethnographic diary reports my astonishment regarding her way of talking about this part of her story as if it was "normal," that is to say, without showing any facial or other expression of sorrow. Among the possible motivations could be her underestimation of the phenomenon, and its extensive occurrence among the women she knows.

He [Mohammed] does not want to go to his father. His father beat me. He was 4 so he remembers...maybe it is for this reason, I don't know. I always ask him: "Do you remember when...[Dad beat me]?" I do so trying to understand his sentiments...but he escapes and says, "No Mum, not now.'

We [Nadia A. and her ex-husband] always made a mess at home...He [Mohammed] was always in the middle. People started calling the police...He started taking drugs. He hit me while I was breastfeeding and my breast became like a faucet...now I have one [breast] big and one small!

\footnotetext{
${ }^{164}$ Like Mehdi, Suad's son, Mohammed was born in Italy, but is not entitled to citizenship under Italian law. See note 96.

${ }^{165}$ The section on "Maternal love", in this chapter, explores Mohammed's story in more depth and Nadia A.'s tangible everyday ways of exercising her love toward him.
} 
Then I went for 5 or 6 months to a building [struttura ${ }^{166}$ or social service building] with other women until I could find a job...but he always came there making a mess out of the house! This was not good for those women whom I lived with ... if I went to the city center ${ }^{167}$ he followed me.

That is when her experience as a squatter began. She is now unemployed, with some legal charges against her because of previous squatting-like other women from the original group — but she feels "calm, because now I am alone with my child" Her husband now lives in Beni Millal, in Morocco. He had to return because he did not have legal documents.

Fatima, Arkiya's younger daughter provides the following testimony about femicide, in general, and her mother's experience in particular.

Fatima: Practically, if a man treats a woman badly, or he beats and almost kills her, if a woman calls the police in Morocco, they don't arrive till she is dead. In Italy, on the contrary, they come quickly.

Me: And how do you know such a thing?

Fatima: One day my mum told me so...because a woman she knew is dead...She told me she was killed because she was pregnant of a girl. A girl...she was killed because she was not going to give birth to a boy. She called the police in Morocco, but they came too late. In Italy they come quickly... Once my mum called the police and they came very quickly! Even ambulances...in Morocco they don't come...If I am pregnant and I need something they don't give the therapy till you give them money... They don't care...In Italy, yes, they care.

\footnotetext{
${ }^{166}$ It is interesting to note that struttura is the term used by all the interviewed women to refer to the same thing. It is a kind of understood code among them, even if in Italian the word itself does not mean what they refer to without any specifying adjective. However, it is directly understood among women who experienced more or less the same difficulties and processes in their lives.

${ }^{167}$ The migrant community, at least in the Italian city centers, tend to have some fixed meeting spaces for leisure, talk, and praying. These geographical areas vary among communities of different nationalities.
} 


\section{Maternal love}

Marwa wears a key as a necklace. When I asked her what this meant, Nadia A. answered, seriously: 'It is the key to her mum's heart' (i.e., Nadia M.)

Maternal love is a topic that still generates a lot of debate within Western feminism. Embedded with a certain degree of spirituality through symbolism and essentialism, ${ }^{168}$ or considered to be merely a cultural construction of patriarchy, there is no doubt that its social importance still prevails. As Ruddick (1980) has argued, "maternal thinking" makes women simultaneously powerless and powerful. They are rendered powerless by being frequently denied the chance to make decisions regarding their own mothering, conducted in proper socio-economic, geo-political (e.g., militarized contexts), and sanitary conditions. This is especially true for some of the mothers of the squat, who were forced into motherhood by their husbands or by the imposition of cultural norms that establish motherhood as the duty of good wives. This is true especially for Nadia M. and Arkiya. In Arkiya's case, her husband was not happy, because she did not bear a boy after delivering two girls_-Fatima and Nadia (Maher, 1989).

Moreover, children are sometimes associated with economic and legal problems. Nadia A. had to endure a 4-year separation from her son Mohammed, who was cared for by her mother-in-law in Morocco after her separation. She could not afford to keep him in Italy, either legally or economically. When she was living in a municipality house after escaping from her violent relationship, she sent him to Morocco the day after some social workers came and told her to "get him ready because a proper family was going to take him." This episode fortunately ended with their reunion.

The situation was the same for Nadia M., who, after the tragic ending of her relationship, was forced to leave her two youngest sons with her mother-in-law in Morocco, because she feared that social service staff could take them away from her. She cares for them from a distance as best she can, especially by sending packages of clothes and food. Arkiya had to send her daughters to Morocco for long periods in the care of her sisters-in-law, because her mother is very ill with cancer and she does not have a father. As previously discussed, women seem to be available if another woman is

\footnotetext{
${ }^{168}$ One interesting development of this strand can be found in the ecofeminist movement. The essentialized connection drawn between women and nature, which many Western feminists considered to be a dangerous one, has generated some critiques that are particularly directed toward Vandana Shiva, one of the first eco-feminist theorists (Mies \& Shiva, (1993).
} 
in need. Arkiya's only son never came to Italy, because her ex-husband did not want him to. Now that she is working legally, she is "trying to do all she can" to get him here, but without success. "He also wants to come to Italy... he also wants to travel, be able to speak some languages...he loves Italy," says his sister Fatima.

None of the fathers seem to care, economically or sentimentally. The only exception is Khadija's second husband, whose parenting practices, however, do not fit into an analysis of migration, because he lives in Libya. ${ }^{169}$ Daughters also do not seem to ask for their fathers or show that they miss them. I asked Fatima:

Me: Are you not sad about not seeing your dad?

Fatima: Why? He went away and he doesn't remember us, he doesn't care about us. So I don't care about him either. I have forgotten about this person...He lives by himself, we live on our own.

However, the situation with sons is different. In Mohammed's case, Nadia A. told me that he remembers when her husband beat her, even though he was only 4 years old.

Do you miss him? Do you want to see him? I always ask him...but he answers no...

Mohammed's aggressive behavior is nonetheless symptomatic of his sadness that he does not express in words (Maher, 1989). Currently Nadia A. is trying to find affordable psychological help for him. ${ }^{170}$ Such behavior totally contrasts with his behavior at home toward his mother. He is the oldest child in the squat. The other boy is Suad's son, Mehdi, who was born in the squat. Mohammed's masculinity indeed offers an interesting topic of inquiry, but an analysis of its characteristics is beyond the scope of this thesis. He is evidently engaged in a continual struggle with the normative gender role that constrains his open expression of his feelings of sadness. I asked his mother:

\footnotetext{
${ }^{169}$ Khadija's only daughter is now 20 years old. Thanks to the support of both Khadija and her Libyan father-who often visits her in Morocco and helps her economically too - she is able to live alone in Marrakech and is studying to become a lawyer. Khadija showed me her picture with sadness: Morocco is very close, but she has not seen her for 2 years. But, she says, laughing, "we talk on WhatsApp...every 2 hours!" (Bartolomei, 2007).

${ }^{170}$ Not many schools in Florence seem to have an attached psychologist to help children whose parents cannot afford a private psychologist.
} 
Me: If you were asked to describe your son, what would you say about him?

Nadia A.: He has character... he always wants to be on his own. I ask him, 'what's wrong? And he answers, "leave me alone...you women speak too much!'

The latter especially testifies to Mohammed's struggle not to identify with typically devalued women's behaviors (speaking too much). In doing so, he is affirming and differentiating his gender as masculine (Chodorow, 1974).

As Nadia A. told me, he feels "ashamed" of living in a squat, and any friend ever came to play there (Zontini, 2010). He removed the squatters' movement banner hanging from the balcony. Unlike Mohammed, Arkiyas' son, back in Morocco, expressed those feelings. As Nadia and Fatima told me, he said, "I miss him...I am without Dad” (Treacher Kabesh, 2013a, 2013b).

In the case of Nadia M.'s daughter, Marwa, her father, Adil, who does not work at all now because of his disability caused by his car accident, sometimes meets her at a big park in Florence, Le Cascine, where she goes roller-skating, during the weekends. Nadia M. accompanies Marwa to the park and leaves her at a distance when she sees him coming. Afterword, she mostly goes straight to her father-in-law house to clean up. Apart from just recently starting to engage in this paternal and enjoyable task, Adil does not contribute at all in practical ways as a father, not even economically. Marwa does not ever ask for him. It seems to me that he represents for her merely a means of enjoying some hours of happiness and play that her mother, tired from coping with a thousand duties and problems, cannot provide.

In addition, living in a squat at the current time represents a bigger problem because of some legislative changes. Article 5 of "Decreto Lupi" directly affects women as mothers and care providers since it complicates important tasks such as assigning a family doctor and enrolling children in schools ${ }^{171}$ with the possible consequence of social workers' intervention.

Sometimes children are the means for women to "escape" a certain degree of control that men exert over their lives (Guessous, 1993). Giving birth to a child and accomplishing the "natural tasks" that the prevailing culture still assigns to mothers is sometimes a way for women to free themselves from men's constant control.

${ }^{171}$ See paragraph “Squat and Migration” in Chapter Two, and note 112. 
Mothering sometimes makes women powerful too. Children are often a source of support and help in such a precarious and suffering existence. Suad currently exudes visible happiness and hope because of her newly-born Mehdi.

I would add that the bond between a mother and a daughter is extremely special (Chodorow, 1974; Maher, 1989). Even if a daughter is still excluded from the same benefits and privileges accorded to a son, the mere fact of being born as girls sometimes results in an apparently higher value accorded to them by their mothers. This value, derived from a cultural construction that requires daughters to be self-sufficient, assistants, and providers of care for others from the very beginning, seems, however, to create a special bond of common perception, and, I would venture to add, without any essentializing intent, mutual feeling between mothers and daughters (Chodorow, 1974). This appeared to me to be especially true in a transnational and precarious context such as the one under study. Nonetheless, we must attend to the fact that this particular mother-daughter identification could lead to a daughter's difficulty in differentiating themselves from their mothers, mostly in terms of their future independent choices (Chodorow, 1974). This aspect is even more emphasized within the Western nuclear family, wherein mothers represent the "center of the family world" (Chodorow, 1974:60). It could be argued that my actual case study represents a transformation from an extended family, typical of Arab societies, to a nuclear family in a migratory context, and further, to the even more extreme case of single mothers as the "family world." How the relationship between mothers and daughters develops in a given context, and, especially, what kinds of gender practices and "differentiation" (Chodorow, 1974) the daughters develop in the future, considering the clashing family paradigms that they are exposed to, will be an interesting study to undertake at a different moment.

The following interview of Arkiya's daughters, Fatima and Nadia, is aimed at demonstrating the special connection between mothers and daughters, expressing how they both feel and how they refer to their mother and appreciate her daily efforts and strength.

Fatima: My mum sometimes goes away for work even up to 3 days. I miss her and I also cry.

Nadia: My mum, she is quite strong. Because when she broke up with Dad she didn't suffer a lot...she was unemployed. But she didn't abandon us. She did 
everything for us. Even if her life was difficult, she did everything she could for us to live a decent life... Sometimes she feels sad, but doesn't show it."

Me: And how do you know that she feels sad?

Nadia: She thinks a lot...I know that she feels bad. Sometimes when she is angry she says: 'Is this life?'... When we see her like this, we don't ask for anything, we know.

Me: Do you think that it is natural for a mum to care more for her children?

Nadia: Yes.

Me: Why do you think so, if children are born thanks to a mother and a father?

Fatima: Sometimes when a mother gives birth to a girl and he [the dad] wants a boy, he does not care.

Me: Why do you think so?

Fatima: Because in our religion [Islam] they care a lot about males. We as women also want girls, because afterward, daughters care for us...Males don't care for us that much. If, when I get older, I give birth to a son, he won't care for me then... He won't remember what I did for him. He will go away, and leave me...Yes, they show it on television too.

Me: Why do you think males behave like that?

Fatima: Because men don't have a soul to think.

Me: Why do you think so?

Fatima: Because men are not very strong...men do not even cry.

Me: Is that a good thing in your opinion?

Fatima: No. I never see them crying in my life.

The significance of this interview speaks for itself. I believe it is important to stress the value accorded to women's emotionality as being greater than that of men, in contrast to the predominant argument that Western patriarchal culture still uses to discredit women within every field. The extent of the appreciation of emotionality expressed by these young women as opposed to their denigration of this emotionality, is surprising. Moreover, it should be noted that among the causes of Moroccan cultural patriarchy, they cite Islam, appearing to clearly understand and acknowledge their mother's struggle to enable them have a better life. Evidently, in their way of speaking, they seem to distance themselves both from how Islam is generally lived and from how Moroccan people generally act using the words: "they" or "them." 
Nadia has a slight degree of disability ${ }^{172}$ that sometimes makes it difficult for her to speak as well as her 14-year-old peers. What is significant is that this minor handicap does not seem to weigh in on the consideration accorded to her by every woman in the squat, starting with her mother, of being "equal" and self-sufficient.

Nadia M.'s care for Marwa, her 10-year old daughter, is another example of this mother-daughter relationship. Marwa is her mother's helper, and partly responsible for her mother's strength. Marwa told me that she wants to become a "mu'allima" (engineer), and her mother spurs her on to study harder, so that she does not become "like her." It is also very interesting to note how this particular squat of single women seems to represent an experiment for creating a better society and at least, in part, subverting normative gender roles (Zontini, 2010). This primarily affects the youngest women of the house, who were exposed during their growing up years to different and non-codified models.

Maternal love actually displays itself in many concrete forms in the specific case study of the squat. Above all it is exemplified in the care of mothers for all of the children within the community, as it was in older practices (Maher, 1989; Treacher Kabesh, 2013a; Lutz, 1997), both in Morocco as well as in Italy. In addition, given the limited privacy in the squat, these children even if they were the only children of their mothers, grew up without experiencing the feeling of being an only child, special and spoiled. Every child, regardless of her/his age, is given some level of responsibility, and they understand the daily efforts that their mothers make to enable them to live "normal" lives as children. As Mohammed told me, while I watched his mother Nadia A. making bread, surprised of her expertise, "she is good at everything."

The concrete forms that love takes are made up of little attentions too. To cite just one example that is inscribed into the sensibility of everyday life, when Mohammed had to go on a school trip, Nadia A. complied with whatever was required to make him to feel "normal":

Listen Mum, make a proper sandwich, with fruit juice which has the 'brand' written on it ... at least for today, Mum!

\footnotetext{
${ }^{172}$ From her distinctive facial features, it appears that she probably has a low level of Down's syndrome.
} 
Transnational motherhood, (especially as a practice of single parenting), has been studied from a feminism perspective, especially in light of what has been described as the "global restructuring of care" (Cheng, 2004:136). In the context of mothers' spatial distance from their children, feminist scholars have highlighted displays of motherhood, especially in terms of the "fragmentation" of its practice given the geographical distance, of "diverted mothering" that results from channeling love to other's children rather than to those of their own, who are far away (Cheng, 2004). They have also highlighted "commodification" in terms of the almost exclusive priority given to materiality and gifts sent by mothers from the western capitalist world to their children left behind in their native countries (Coe, 2011; Cheng, 2004; Gedalof, 2009). All of the aforementioned aspects disrupt the idea that normative motherhood is alike globally. It is, instead, based on privileged women's experiences (Cheng, 2004). Furthermore, if motherhood in general is legitimated by institutionalized state policy and rhetoric that have implications for, among other fields, the job market, ${ }^{173}$ then migrant mothers are even more captive within structural and intimate violence realized through nationalist racial projects (Cheng, 2004). The widespread difficulty experienced by caregivers in bringing their children when living in the employer's house is one concrete example of this situation (Nadia M. is currently hoping to be allowed to move with Marwa to her employer's house).

The majority of studies, however, focus on the difficulties and struggles of mothering at a distance. Less attention has focused on place (Massey, 1994), not only in terms of mothers symbolically being the "place," viewed as static, immanent, and "repetitive, in relation to the work of reproduction itself, but also through a contrasting conceptualization of place as dynamic and changing over time, and as geography, leading to necessarily new and dynamic forms of mothering too (Gedalof, 2009). As Gedalof suggests, a new and useful way of thinking of mothering in the context of migration is to think in terms of the "repetition that undoes" (2009:96), that is to say the dynamic combination entailed in mixing new and familiar mothering and cultural practices (e.g., food). Conceptualized this way, motherhood could challenge the reification of the reproductive sphere as one of the purest "indigenous" and untouched forms of culture in migration Gedalof, 2009). This would, moreover, contribute to further theorization of domestic work as a whole.

\footnotetext{
${ }^{173}$ Feminist economists have done a lot in this regard. Among others, these includeAmaia Pérez Orozco, Cristina Carrasco, and Lina Gálvez.
} 


\section{Leaving the squat, \\ rethinking travel within women's stories}

In this section I will bring together some themes that have been briefly touched upon in previous sections with the intent of deepening them further. These topics are, in order: (a) women's veiling practices, (b) normative gender roles, (c) the importance of the economy in relation to love, (d) sisterhood and "commons" economy, and (e) the role WhatsApp and other technological devices in the practice of motherhood.

I will begin by developing a hardly discussed aspect of the topic of the veil. Probing deeper into topic, let alone somehow positioning myself within a debate that has long been a hot one in the West, mostly ending in a useless but harmful ideological war between Western "secularism" (insightfully described as "sexularism" by Scott [2009]) and Muslims, is beyond the aims of my research. Rather, I am rather interested in what Bilge has called the "contextual interactive aspect" (2010:21) of veiling among the majority of the women subjects of this research, which connects more to feminist debates about agency (Abu-Odeh, 1993; Bilge, 2010; Bracke, 2008; Braidotti, 2008; Mahmood, 2001; Midden \& Ponzanesi, 2013; Scott, 2009; Göle, 2010) than to the veiling debate itself. Most of the subjects of my research did in fact veil themselves just when they were in Morocco, apparently motivated by "cultural shame," 174 as frequently mentioned in the interviews, more than because of religiosity. Conversely, in the Italian context, they "unveil" strategically. Among the reasons for this could be the will not to be discriminated against when applying for jobs (as Hanan's interview testifies), but also the almost nonexistent control of men over their bodies. Vanessa Maher (1989:13) has noted this performativity of identity through the veil among Moroccan women in relation to the change brought about by the movement between rural and urban areas. Extending her observations to the contemporary world, we could argue that transnationalism has added a considerable degree of stress to such performances. Another underlying motivation for not wearing the veil in Italy among the women subjects of this study is the limited extent of their religiosity, despite the ostensible display of religious symbols and phrases used in their WhatsApp profile pictures. ${ }^{175}$ The visibility of religious attachment within social media is a current topic of interest

\footnotetext{
${ }^{174}$ See note 50 .

${ }^{175}$ Some of the women's WhatsApp profile images can be found in the Appendix Two.
} 
(Midden \& Ponzanesi, 2013), the cultural motivations for which could lie in an individual's search for her or his own traditional heritage, given the nature of our continually de-territorializing world. Moreover, what I interestingly noticed while conducting the interviews in Italian was that Moroccans almost never used the widespread expression indicating God's view in Arabic culture (Inshallah, or if God wants). This did not even feature as an Italian rendering (Dio, Se Dio vuole). This is indeed a linguistic practice that goes against what I have experienced while living in this region and conducting fieldwork, especially in Morocco and Tunisia. Such expressions were, on the contrary, used extensively by Maria, a Romanian woman whose deep religiosity is a matter of fact. I, therefore, advocate, in line with Bilge (2010), the importance of applying an intersectional and contextual approach in relation to the veiling issue. Moreover, we should recall "the fact that veiling, in particular contexts, may help attain extra-religious ends in secular domains" (Bilge, 2010:20). Islam does not allow for the future reversal of women's decisions to veil themselves as an act expressing faith. However, practices sometimes appear to escape and develop in different ways from what religious laws dictate. Moreover, I would like to simply conjecture here, leaving this argument to be examined in another study, that perhaps Muslim women who migrate without men are not inclined toward the cultural phenomenon of "re-islamization" as a search for "identity," unlike men (Gandolfi, 2001).

However, "instrumentality" and "strategy" also relate, in this case study, to another practice that I observed concerning gender roles. As already noted, Nadia A. and Hanan strategically deploy their gender role and the associated skills, above all, cooking, to gain something for themselves, especially in economic terms. They cook traditional dishes for Moroccan "friends," whose wives are not with them, in exchange for food and money.

The economic element is a fundamental one in relation to the topic of love that I attempted to deconstruct throughout this study. The concreteness and materiality of love seems to be the most important aspect in a female-male relationship. In line with Maher's (1989) findings, economy and money, either concretized as wedding jewelry or money provided for children, seems to constitute one of the most important aspects of a relationship for women. Disagreements about money, in general, consequently seem to be a primary cause of separation. Confirming what was stated in Chapter One, the importance of economy serves to challenge the idea of love's intangibility (Coe, 2011; 
Esteban Galarza, 2008, 2011; Maher, 1989; Mernissi, 1988; Mir-Hossein, 1994; Roca y Girona 2012-2007; Watson, 1994).

Moreover, "sisterhood" (hooks, 1986), uncaring of blood bonds, and the establishment of "female nets" (Maher, 1989) to supply other women's necessities was a constant theme, linguistically and tangibly, throughout the chapter. By establishing "commons" as an alternative economy based on shared care, food, and activities (Maher, 1986; Federici, 2010), women fill the gaps left by the inconsistencies of men's assistance — and love — in their lives.

Lastly, it is interesting to note how mobile phones have come to represent the door to a world of intimacy and sentiment, both because they enable transnational communication ${ }^{176}$ and because of their function as a contemporary "family" album. In this case, the family is made up of a mother and her children. Other mothers often interrupted our interviews to show me pictures of their far away sons that sometimes also featured on their WhatsApp profile pictures. Modern, digital, "family albums" opened up for me a world made up of different personalities in different contexts, a performativity of selves that sometimes complicated for me their recognition in their native countries, while veiled.

\footnotetext{
${ }^{176}$ Especially via Whatsapp and Skype.
} 


\section{Conclusions}

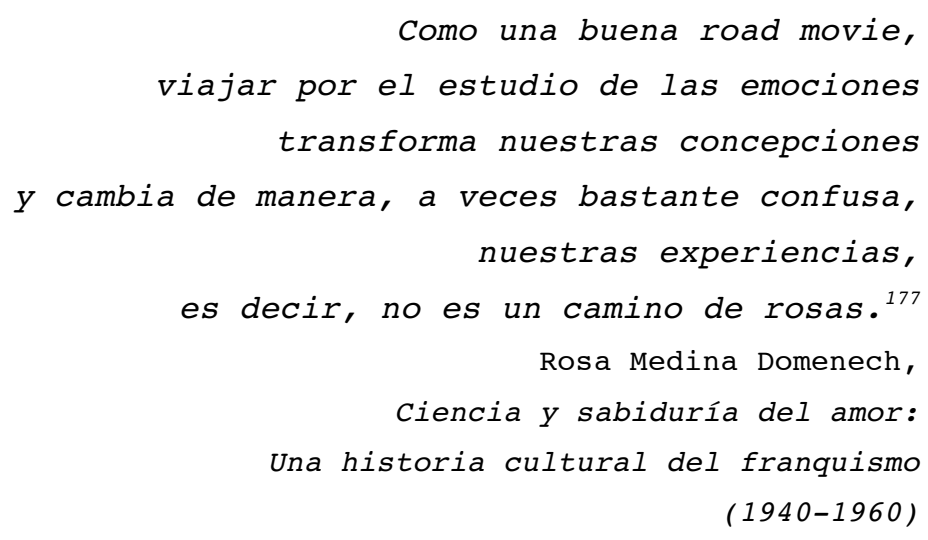

I open these concluding remarks with a response to the provocative lines by Esteban Galarza, Medina Doménech, and Távora Rivero with the intention of highlighting the richness and value of my ethnographic experience: "Why investigate love if there are 'apparently' more urgent questions affecting women's lives, like migration or the job market?"178 (2005:1). My response to this is because love, apart from being a core field of analysis for feminism (hooks, 2002), is part and parcel of both migration and the job market. The women's life stories, presented in this thesis, enable the links that bind love to these fields to be sought out and followed. At the end of this travel, I argue from a feminist perspective that we need to better understand this intertwining to be able to formulate new interventions aimed at improving migrant women's lives that could also account for love and not just formal rights for migrants. Love and emotions are factors that engender damage as well as new kinds of fulfilment and support in migrant women's lives, thereby contributing to the subversion of passive stereotypes attached to their bodies. Emotions on the move extend beyond those of belongingness, estrangement, and nostalgia for a distant land (Ahmed, 1999; Christou, 2011; Salih, 2003). Love is daily manifested as a normative power that oppresses many migrant women whose lives are invisible. The stories presented here are the testimonies of empowered women who managed to survive their lovers' oppression. They also managed to transform love energy, giving birth to new kinds of positive relationships

\footnotetext{
${ }^{177}$ Like a good road movie, travelling across the studies of emotions transforms our conceptions and changes, sometimes confusingly, our experiences. That is to say, it is not a bed of roses (My translation from the Spanish text).

${ }^{178}$ My translation from the Spanish text.
} 
that challenge entrenched notions of the nuclear family and household. Through the medium of the squat, they demonstrated that new forms of cohabitation are possible. Nonetheless, because of their status as squatters and illegal migrants, their living conditions remain precarious. However, this may be a better life for them than one that entails multiple injustices disguised as love.

Prevalent themes in the past love stories of the migrant women I interviewed ranged from the gendered norms of being good wives and mothers to forms of psychological and physical violence. These are long-standing behavioral patterns associated with patriarchy. However, I have stressed the new dimensions of these forms of control in a migratory context. The women's present love stories put into the foreground the promising possibilities offered by "sisterhood" (hooks, 1986). Despite some frictions that may occur especially when linguistic differences interfere among the women ${ }^{179}$, solidarity, displayed emotionally or concretely, is indeed something powerful. Women present love stories' manifest also as empowered motherhood. The squat constitutes both a physical living space as well as the place (Massey, 1994) for deconstructing normative gender roles, and establishing a "commons" characterized by mutual assistance, economic and otherwise (Federici, 2010, 2012). Motherhood, and children growth, got influenced in new ways by the "community" dynamics of the squat itself.

This thesis interrogates multiple layers of stereotypes. First, it challenges the universality of romantic love, revealing its cultural "nature." As the subjects of my thesis noted, love for Muslim women has more to do with economic materiality and goods than with intangible sentimentality. It is not all encompassing as Western romantic love purports to be. Husbands are not all round life companions for Muslim women. Rather, their relationships are the outcome of women's calculation and reasoning. Women often manage to keep intact strong female bonds during and after marriage. ${ }^{180}$ Thus, the thesis challenges the idea of Muslim women as dependent and subjugated. Men's love power could subsequently take oppressive forms toward them.

\footnotetext{
${ }^{179}$ Especially Maria, the Romanian woman, was the woman who felt more excluded among the group I met, especially because of her incapacity to understand Arabic. Nonetheless, the other women help her in concrete ways. I did not have the chance to interview the two Nigerian women. Nonetheless, from some informal conversations I had both with Moroccan women and with the Romanian woman, it was clear that the Nigerian women were not totally outsiders. They help reciprocally with the other squatters in concrete ways, despite their different cultural habits did not inspire them to share free time together.

${ }^{180}$ This is also confirmed in my personal experiences in Arabic countries. I have observed women collectively making strategic calculations before accepting a marriage proposal.
} 
Nonetheless, the women who feature in this thesis found different ways of escaping from and rearticulating this insane love (Berlant, 2011) with reasoned strategies, despite the lack of social support available to them in the migratory context.

Second, two interesting findings emerged in light of the deconstruction of Muslim women's passiveness that could stimulate possible future research. Both have to do with the performativity of identity and its deployment in a transnational context. The squat, being a subversive place, was particularly conducive to manifestations of this performativity of identity. I refer especially to the contextual and instrumental use of the veil and of certain normative gender roles. Many of the subjects of this thesis wear the veil only in Morocco and not in Italy. They justify their strategic use of the veil in terms of a culturally imbued sense of "shame" experienced by unveiled women in Morocco, and, conversely, by the cultural stereotyping they encounter in Italy. Strategic veiling, therefore, benefits them in both contexts. In Morocco, they are able to move freely, being less controlled and less subject to gossip. In Italy, they can escape visible categorization as a Muslim and access more opportunities, starting with the job market. A future research inquiry could consider the role of new technologies such as WhatsApp and social media, not just as media of transnational communication, but also related to the performativity of the self. ${ }^{181}$ For example, I noted some of the women's strategic performances of their feminine "skills" — cooking and cleaning_for male emigrated companions to acquire economic benefits.

Other possible research avenues for expanding the findings of this thesis could consider the development of masculinities and femininities of the children living in the only-women squat, as a place of deconstruction and subversion of normative gender roles. Children are in fact undergoing what I would describe as an "extreme performance": becoming adults.

To conclude, what I bring home from this journey is a richly colored and textured, fluid, and three-dimensional photograph that shows the complexity of emotional relationships within a continuously changing world.

\footnotetext{
${ }^{181}$ As noted in Chapter Three, page 86, I was not able to recognize some of the women from the WhatsApp profile pictures they showed me, in which they were veiled in Morocco.
} 


\section{References}

Abu-Odeh, Lama (1993), "Post-colonial Feminism and the Veil: Thinking the difference", Feminist Review, n. 43, pp. 26-37.

Abu-Lughod, Lila (1986), Veiled Sentiments. Honor and poetry in a bedouin society, Berkeley, University of California Press (Trad. it. 2007, Sentimenti velati. Onore e poesia in una società beduina, a cura di Maher Vanessa, Torino, Le Nuove Muse).

Abu-Lughod, Lila (2000), "Locating Ethnography", Ethnography, SAGE publications, 1, n. 2, pp. 261-267.

Abu-Lughod, Lila (1990) "Can there be a feminist ethnography?". Women and Performance: A journal of Feminist Theory, 5, n. 1, pp. 7-27.

Abu-Lughod, Lila (2002) "Do Muslim Women Really Need Saving? Anthropological Reflections on Cultural Relativism and Its Others", American Anthropologist, 104, n. 3, pp. 783-790.

Ahmed, Sara, (1999) "Home and Away. Narratives of Migration and Estrangement", International Journal of Cultural Studies. 2, n. 3, pp. 329-347.

Ahmed, Sara, (2014), The cultural politics of emotion, Edinburgh University Press.

Al-Ali, Nadje, "Women, Gender and Migration in Europe", http://www.comune.forli.fo.it/ Documenti/39/gender.pdf

Alamri, Yassar Abdullah (2011), “Abortion and Islam”, Jima, vol. 43, pp. 39-40.

Alcázar Campos, Ana (2011) La Cuba de verdad: construcción de alteridades y turismo en la contemporaneidad. Granada: Universidad de Granada.

Alcázar Campos, Ana (2014) ""Siendo una más". Trabajo de campo e intimidad”, Revista de Estudios Sociales (Bogotá), Tema: Sexualidades e interseccionalidad en América Latina, el Caribe y su diáspora, n 49, pp. 6071.

Andall, Jaqueline (2000), “Organizing Domestic Workers in Italy: The Challenge of Gender, Class and Ethnicity" in Gender and Migration in Southern Europe: Women on the Move, Oxford \& New York: Berg, pp. 145- 171.

Andrade, Adriana García (2013), "Una lectura del amor desde la sociología: algunas dimensiones de análisis social”, Sociológica, 28, n. 80, sept-dic, pp. 155-188; 
Anthias, Floya \& Lazaridis, Gabriella (2000), "Introduction: Women on the Move in Southern Europe" in Gender and Migration in Southern Europe: Women on the Move. Oxford \& New York: Berg, pp.11-14.

Anthias, Floya (2000), "Metaphors of Home: Gendering New Migrations to Southern Europe" in Gender and Migration in Southern Europe: Women on the Move. Oxford \& New York: Berg, pp.15-47.

Appadurai Arjun (1996), Modernity at Large: Cultural Dimensions of Globalization, Minneapolis-London, University of Minnesota Press. (Trad. it. 2001, Modernità in polvere. Dimensioni culturali della globalizzazione, Roma, Meltemi).

Aspesi, Natalia (2014), Sentimental. Diario Italiano di Amore e Disamore. La Repubblica, Laterza.

Atencia Escalante, Javier (2005), "Antropología y emociones: Geertz y Taylor", Thémata: Revista De Filosofía, n. 35, pp. 451-456

Barriteau, Violet Eudine (2011), "Theorizing Sexuality and Power in Caribbean Gender Relations" in Jónasdóttir Anna, G., Bryson Valerie and B. Jones, Kathleen (eds.), Sexuality, Gender and Power, Routledge, New York, pp. 7592.

Bartolomei, Maria Rita (2007), "Famiglie transnazionali e crisi del patriarcato. Gli Indiani del kerala residenti a Macerata", in Ambrosini, Maurizio, Berti, Fabio (eds.), Persone e migrazioni, Integrazione locale e sentieri di co-sviluppo, Franco Angeli, Milano.

Bastia, Tanja (2009), "La feminización de la migración transnacional y su potencial emancipatorio", Papeles De Relaciones Ecosociales y Cambio Global. n.104, pp. 67-77.

Berlant, Lauren (2012), Desire/Love, Lightning Source Inc.

Berlant, Lauren (2000), "Introduction" in Berlant, Laurent (ed.), Intimacy, The University of Chicago Press, pp. 1-9.

Berlant, Lauren (2011), “A properly political concept of love: Three Approaches in Ten Pages", Cultural Anthropology, 26, n. 4, pp. 683-691.

Best, Amy, (2003) "Doing Race in the Context of Feminist Interviewing”, Qualitative Inquiry, 9, n. 6 .

Bhabha, Homi (1994), "Introduction" in Locations of Culture, Routledge, New York, pp. 1-27. 
Bilge, Sirma (2010), "Beyond Subordination vs. Resistance: An Intersectional Approach to the Agency of Veiled Muslim Women", Journal of Intercultural Studies, 31, n.1, 9-28.

Bimbi, Francesca (2011), "Genere e violenza al tempo delle migrazioni globalizzate" in WorldWideWoman: Globalizzazione, Generi, Linguaggi, CIRSDe, Centro Interdisciplinare di Ricerche e Studi delle Donne, pp. 91-101.

Boccagni, Paolo (2010), "Exploring migrants' affective ties at a distance: is 'multi-sited' ethnography enough?", Working Papers, Centre on Migration, Citizenship and Development, n. 72, pp. 1-17.

Boehm, Deborah A. (2011), "Deseos y Dolores: Mapping Desire, Suffering, and (Dis)loyalty within Transnational Partnerships", International Migration, 49, n. 6, pp. 95-106.

Boym, Svetlana, (2000), “On Diasporic Intimacy: Ilya Kabakov's Installations and Immigrant Homes" in Berlant, Lauren (ed.), Intimacy, The University of Chicago Press, pp. 226-253.

Bracke, Sarah (2008), 'Conjugating the modern/religious, conceptualizing female religious agency: Contours of a 'post-secular' conjunction', Theory, Culture and Society, 25, n.6, pp. 51-67.

Braidotti, Rosi (2008), "In Spite of the Times: The Postsecular Turn in Feminism." Theory, Culture, \& Society, 25, n.6, pp. 1-24.

Butler, Judith (2008), "Sexual politics, torture, and secular time", The British Journal of Sociology, 59, n. 1, pp. 1-23.

Casado Elena y Lasén Amparo (2014), "Epílogo: controversias y desasosiegos metodológicos" in Amparo Lasén y Elena Casado, Mediaciones tecnológicas. Cuerpos, afectos y subjetividades, Madrid, CIS, pp. 153-163.

Chell-Robinson, Victoria (2000), "Female Migrants in Italy: Coping in a country of new migration" in Gender and Migration in Southern Europe: Women on the Move. Oxford \& New York: Berg, pp. 103-123

Cheng, Shu-Ju Ada (2004), "Right to Mothering. Motherhood as a Transborder Concern in the Age of Globalization”, Journal of the Association for Research on Mothering, 6, n. 1.

Chodorow, Nancy (1974), "Family Structure and Feminine Personality" in Rosaldo, Michelle and Lamphere, Louise (eds.), Woman, Culture and Society, Stanford University Press, pp. 48-67. 
Christou, Anastasia (2011), "Narrating lives in (e)motion: Embodiment and belongingness in diasporic spaces of home and return", Emotion, Space and Society, 4, pp. 249-257.

Cioce, Gabriella (2015), Una etnografia della resistenza: il Movimento di Lotta per la Casa di Firenze e la legge Saccardi, Università di Siena, Laurea Magistrale.

Coe, Cati (2011), "What is Love? The Materiality of Care in Ghanaian Transnational Families", International Migration, 49, n.6, pp. 7-24.

Collins, Patricia Hills (1998) "It's All in the Family: Intersections of Gender, Race, and Nation", Hypatia, 13, n. 3, pp. 62-82.

Coontz, Stephanie (2006). ""Ha llegado el momento de que se muevan las montañas": del matrimonio sentimental al sexual" in Coontz, Stephanie (ed.) Historia del matrimonio. Cómo el amor conquistó el mundo, Barcelona, Gedisa, pp. 257-281.

Crenshaw, Kimberlè Williams (1991), "Mapping the Margins: Intersectionality, Identity Politics and Violence Against Women of Colour", Stanford Law Review, 43, n.124, pp. 1241-1299.

D'Odorico, Giulia (2014), "Genere e sessualità. Madri e figlie tra Marocco e Italia”, Tesi di Dottorato, Università degli Studi di Padova.

D’Odorico, Giulia \& Vianello, Francesca Alice (2011), "Le definizioni della violenza sulle donne in contesti migratori: verso un vocabolario transculturale", in WorldWideWoman: Globalizzazione, Generi, Linguaggi, CIRSDe, Centro Interdisciplinare di Ricerche e Studi delle Donne, pp.101-113.

Davis, D. A.Davis, S. S. (1995), "Modernizing the Sexes: Changing Gender Relations in a Moroccan Town", Ethos, 23, n. 1, pp. 69-78.

De Gregorio, Concita (2008), Malamore. Esercizi di resistenza al dolore, Mondadori, Milano.

DeVault, Majorie L., and Glenda Gross (2007), "Feminist Interviewing: Experience, Talk, and Knowledge" in Hesse Bieber (ed.), Handbook of Feminist Research, Sage.

Dreby, Joanna (2009), “Gender and transnational gossip", Qual Sociol, 32, pp. 33-52.

El Feki, Shereen (2013), Sex and the Citadel: Intimate Life in a Changing Arab World, Anchor.

El-Saadawi, Nawal (1991), La cara desnuda de la mujer árabe, editorial Horas y Horas, Madrid (original edition 1977, The hidden face of Eve); 
Esteban Galarza, Mari Luz (2011), Crítica del pensamiento amoroso: Temas contemporaneos, Edicions Bellaterra, Barcelona.

Esteban Galarza, Mari Luz (2008) "El amor romántico dentro y fuera de occidente: determinismos, paradojas y visions alternativas" in Suárez, Martín, Hernandez, Feminismo en la antropología: nuevas propuestas críticas, Ankulegi, pp. 157172.

Esteban Galarza, Mari Luz; Medina Doménech, R.; Távora Rivero, A. (2005), “Por qué analizar el amor? Nuevas posibilidades para el estudio de las desigualdades de género", in Díez Mintegui, C.; Gregorio Gil, C. (eds.) Cambios culturales y desigualdades de género en el marco local-global actual. X Congreso de Antropología. Sevilla: FAAEE-Fundación El MonteASANA, pp. 207-223.

Faier, Lieba, (2011) "Theorizing the Intimacies of Migration: Commentary on The Emotional Formations of Transnational Worlds", International Migration, 49, n. 6, pp, 107-112.

Fawzi El-Solh, Camillia, Mabro Judy (1994), "Introdution: Islam and Muslim Women” in Fawzi El Soth, Camillia and Mabro, Judy (eds.) Muslim Women's Choices: Religious Belief and Social Reality, pp. 1-32.

Federici, Silvia (2012), Revolution at Point Zero. Housework, reproduction and feminist Struggle, Brooklyn/Oakland, Common Notions/PM Press.

Federici, Silvia (2010), "Feminism and the Politics of the Commons" in Craig Hughes, Stevie Peace and Kevin Van Meter (eds.) Uses of a World Wind Movement, Movements and Contemporary Radical Currents in the United States, for the Team Colors Collective, Oaskland: AK Press.

Fisher, Helen E. (1999), “El enamoramiento ¿Por qué él? ¿Por qué ella?” in Anatomía del Amor: Historia Natural de la monogamia, el adulterio y el divorcio, Barcelona, Anagrama, pp. 35-55.

Foffano, Silvia (2007), "La poligamia nel diritto di famiglia islamico in Marocco: la Moudawana", Pace diritti umani, n. 1, genn-apr., pp. 69-94;

Foucault, Michel (2008), "Lecture Nine, 14 March 1979" and "Lecture Ten, 21 March 1979" in The Birth of Biopolitics. Lectures at the Collège de France 1978-1979, ed. Arnold I. Davidson. Hampshire and New York: Palgrave Macmillan, pp. 215-237, 239- 265. 
Fraser, Nancy (1989), 'Women, Welfare, and the Politics of Need Interpretation' in Unruly Practices: Power, Discourse, and Gender in Contemporary Social Theory, Minnesota, University of Minnesota Press, pp. 144-160.

Gandolfi, Paola, (2001), "I migranti marocchini e la cultura berbera nel contesto della migrazione transnazionale", La Ricerca Folklorica, n. 44, Antropologia dei processi migratori, pp. 39-51.

Gedalof, Irene (2009), "birth, belonging and migrant mothers: narratives of reproduction in feminist migration studies", Feminist Review, n. 93, pp. 81100.

Göle, Nilüfer (2010), 'The civilizational, spatial and sexual powers of the secular' in Michael Warner, Jonathan van Antwerpen and Craig Calhoun (eds), Varieties of secularism in a secular age, Cambridge, MA: Harvard University Press, pp. 43-264.

Gordon, Avery F. (2008), Ghostly Matters: Haunting and the Sociological Imagination, University of Minnesota Press.

Gorton, Kristyn, (2007), “Theorizing emotion and affect in Feminist engagements" in Feminist Theory, vol. 8(3), pp. 333-348.

Gregorio Gil, Carmen (2000) "Mujer, blanca, española, rica ... Trabajo de campo en inmigración y relaciones de género". En Francisco Checa Olmo (ed.) Las migraciones a debate. Barcelona, Icaria.

Gregorio Gil, Carmen (2011), “Trabajo y género a la luz de la crítica feminista en antropología social: acercamientos etnográficos", in Villalba Augusto, Cristina \& Álvarez Lucena, Nacho (eds.) Cuerpos políticos y agencia. Reflexiones Feministas sobre el Cuerpo, Trabajo y Colonialidad, Cicode, Granada.

Gregorio Gil, Carmen (2012), "Tensiones conceptuales en la relación entre género y migraciones. Reflexiones desde la etnografía y la crítica feminista.", Papers 97, n.3 , pp. 569-590.

Gregorio Gil, Carmen (ed.) et al. (2010) Porqué tienen que decir que somos diferentes. Las mujeres inmigrantes sujetos de acción política, Universidad de Granada.

Grey, Breda, (2008), "Putting emotion and reflexivity to work in researching migration", Sociology, 42, n.5, pp. 935-952. 
Guessous, Soumaya Naamane (1993), Al di là del pudore, La Luna (original: 1991, Au-delà de toute pudeur. La sexualité feminine au Maroc, Paris, Karthala).

Hall, Stuart (2006), "The West and the Rest: Discourse and Power" in Maaka, C.A, Robert and Andersen, Chris (eds.), The Indigenous Experience: Global Perspectives, Canadian Scholars' Press Inc., pp. 165-174.

Haraway, Donna (1988), "Situated Knowledges: The science question in feminism and the privilege of partial perspective", Feminist Studies, 14, n.3.

Haritaworn, Jin, Kuntsman, Adi \& Sylvia Posocco (2014), "Introduction" in Queer Necropolitics, Oxon and New York: Routledge, 1-27.

Hesse-Biber, Sharlene Nagy (2011), "Feminist Research" in Handbook of Feminist Research, Sage.

Hochschild, Arlie Russell (2015), Per amore o per denaro. La commercializzazione della vita intima, Bologna, Il Mulino, (original: The commercialization of Intimate Life. Notes from Home and Work, 2003, University of California Press).

Hooghiemstra, E. (2001), "Migrants, Partner Selection and Integration: Crossing Borders?", Journal of Comparative Family Studies, n. 32, pp. 609-626.

hooks, bell, (2002), Communion: the female search for love, William Morrow Paperbacks.

hooks, bell (1986), "Sisterhood: political solidarity between women", Feminist Review, special issue: Socialist-Feminism: Out of the Blue, 23, pp. 125-138.

Jaggar, M. Alison (1996), "Love and Knowledge: Emotion in Feminist Epistemology" in A. Garry and M. Pearsall (eds.), Women, Knowledge and Reality: Explorations in Feminist Philosophy, New York, Routledge.

Jónasdóttir, Anna, G. (2011), "What kind of love is love power?” in Jónasdóttir Anna, G., Bryson Valerie and B. Jones, Kathleen (eds.), Sexuality, Gender and Power, Routledge, New York, pp.45-60.

Jónasdóttir Anna, G., Bryson Valerie and B. Jones, Kathleen (eds.) (2011), "Editors' Introduction: Sexuality, Love and Social Theory" in Sexuality, Gender and Power, Routledge, New York, pp. 11-15.

Juliano, Dolores (2000), "Mujeres estructuralmente viajeras: Estereotipos y estrategias (Entrevista)", Papers 60, pp. 381-389.

Juliano, Dolores (2012), "Género y trayectorias migratorias en época de crisis." Papers 97, no.3 pp 523-540.

ISTAT (2015), Bilancio Demografico Nazionale. 
Kipnis, Laura (2000), “Adultery” in Berlant, Laurent (ed.), Intimacy, The University of Chicago Press, pp. 9-47;

Kirsch, G. E. (2005), 'Friendship, Friendliness, and Feminist Fieldwork', Signs, 30, n. 4, pp. 2163-2172.

Lipperini, Loredana \& Murgia, Michela, (2013), "L’ho uccisa perchè l'amavo", Laterza, Roma-Bari.

Lutz, Catherine, Abu-Lughod, Lila (eds.) (1990), Language and the politics of emotion, Cambridge University Press.

Lutz, Catherine (2001), "Emotions and Feminist Theories", www.zefg.fuberlin.de/media/pdf/querelles_jahrbuchaufsatz5.pdf

Lutz, H. (1997), 'The limits of European-ness. Immigrant Women in Fortress Europe' in Feminist Review, 57, pp. 93-111.

Magallón Portolés, Carmen (1991), “La Plusvalía Afectiva,”, En Pie de paz, 17, p. 10.

Magallón Portolés, Carmen (1997) “La política del corazón. Hacia una racionalidad más básica", En Pie de paz, 46, pp. 6-8.

Maher, Vanessa (1989), Il potere della complicità: Conflitti e legami delle donne nordafricane, Rosemberg \& Sellier.

Mahmood, Saba (2001), "Feminist Theory, Embodiment, and the Docile Agent: Some Reflections on the Egyptian Islamic Revival", Cultural Anthropology, 16, n.2, pp. 202-236.

Mai, Nicola \& King, Russell (2009), "Love, Sexuality and Migration: Mapping the Issue(s)", Mobilities, 4, n.3, pp. 295-307.

Massey, Doreen (1994), Space, Place and Gender, Polity Press.

Mbembe, Achille (2003), "Necropolitics", Public Culture 15, n.1, pp. 11-40.

Medina Dómenech, Rosa (2013), Ciencia y sabiduría del amor: una historia cultural del franquismo (1940-1960), Madrid: Iberoamericana

Medina Doménech, Rosa (2012), "Sentir la historia. Propuestas para una agenda de investigación feminista en la historia de las emociones”. Arenal: Revista de historia de mujeres, 19, n.1, pp. 161-199.

Melchiori, Paola (ed.) (2000), Donne del Mediterraneo: identità, convivenze, mediazioni, AICOS, Milano.

Menjìvar, Cecilia, Salcido, Olivia (2002), "Immigrant Women and Domestic Violence: Common Experiences in Different Countries", Gender \& Society, 16, n.6, pp. 898-920. 
Mernissi, Fatima (1975), Beyond the Veil. Male-Female Dynamics in Modern Muslim Society, Bloomington \& Indianapolis, Indiana University Press.

Mernissi, Fatima (1988), Doing Daily Battle. Interviews with Moroccan Women, The Women's Press Ltd.

Mernissi, Fatima (2000), L'Harem e l'Occidente, Giunti (original, 2000, Scheherazade goes West, or: The European Harem).

Midden, Eva \& Ponzanesi, Sandra (2013), "Digital faiths: An analysis of the online practices of Muslim women in the Netherlands", Women's Studies International Forum, 41, pp. 197-203.

Mir-Hosseini, Ziba (1994), "Strategies of Selection: Differing Notions of Marriage in Iran and Morocco" in Fawzi El Soth, Camillia and Mabro, Judy (eds.), Muslim Women's Choices: Religious Belief and Social Reality, pp. 55-72.

Mohanty, Chandra Talpade (2003), ""Under Western Eyes" Revisited: Feminist Solidarity through Anticapitalist Struggles”, Signs 28, no. 2, pp. 499-535.

Montagne, Robert (2000), Ribelli del deserto. Vita sociale e politica dei berberi, L'ancora.

Moore, Henrietta L. (1988) Feminism and Anthropology, Cambridge.

Moore, Henrietta L (1996), "Mothering and social responsibilities in a crosscultural perspective" in Good Enough Mothering?: Feminist Perspectives on Lone Motherhood, Routledge, pp.58-76.

Morini, Cristina (2011), Per amore o per forza. Femminilizzazione del lavoro e biopolitiche del corpo, Verona, ombre corte.

Morokvasic, Mirjana (1984), "Birds of Passage are also Women", International Migration Review, pp. 886-907

Ong, Walter, J. (1986), Oralità e scrittura. Le tecnologie della parola. Il Mulino, Bologna (original edition: 1982, Orality and Literacy. The technologizing of the Word, London and New York, Methuen).

Orsini-Jones, Marina and Gattullo, Francesca (2000), "Migrant Women in Italy:

National Trends and Local Perspectives" in Gender and Migration in Southern Europe: Women on the Move, Oxford \& New York: Berg, pp. 125-144.

Parente, Maria (2012), "Donne in Movimento: la condizione lavorativa delle donne migranti in Italia”, Osservatorio Isfol, 2, n.3, pp. 139-150.

Pepicelli Renata (2010), Femminismo islamico. Corano, diritti, riforme, Roma, Carocci Editore. 
PICUM, Platform for International Cooperation on Undocumented Migrants (2004), "Report on the housing situation of undocumented migrants in six European Countries: Austria, Belgium, Germany, Italy, the Netherlands and Spain.

Pojmann Wendy (2006), Immigrant women and feminism in Italy, Aldershot, Ashgate.

Ponzanesi, Sandra (ed.), (2014), Gender, Globalization, and Violence: Postcolonial Conflict Zones, Routledge.

Preissle, Judith (2006), "Feminist Research Ethics" in Handbook of Feminist Research, Sage.

Riley, Denise (1988), "“The Social”, "Woman”, and Sociological Feminism' in Am I that Name?: Feminism and the Category of "Women" in History, London: The Macmillan Press Ltd, pp. 44-66.

Roca i Girona, Jordi, Yolanda Bodoque Puerta y Montserrrat Soronellas Masdeu (2012), "Migraciones por amor: Diversidad y complejidad de las migraciones de mujeres", Dialnet, 3, n. 97, pp. 685-707.

Rowntree, Margaret (2012), "Women's sexual lives in the new millennium: insights from their daydreams", paper presented at the Cultural Studies Association of Australasia Conference "Cultural ReOrientations and Comparative Colonialities".

Ruddick, Sara (1980), "Maternal thinking”, Feminist Studies, 6, n. 2, pp. 342-367.

Said, Edward (1994), "Introduction” in Culture and Imperialism, Vintage Books, New York, pp. xi-xxviii.

Salhi, Zahia Smail (2013), "Gender and violence in the Middle East and North Africa: Negotiating with patriarchal states and Islamism" in Gender and violence in Islamic societies: patriarchy, Islamism and politics in the Middle East, London, I.B. Tauris, pp. 12-43.

Salih, Ruba (2001), 'Moroccan Migrant Women: Transnationalism, Nation-States and Gender' in Journal of Ethnic and Migration Studies, 27, n.4, pp.655-671.

Salih, Ruba (2003), Gender in Transnationalism: Home, Longing and Belonging among Moroccan Migrant Women, London, Routledge.

Salih, Ruba (2008), Musulmane rivelate. Donne, islam, modernità, Roma, Carocci.

Sassen, Saskia (2000), “Women's burden: Counter-geographies of Globalization and The Feminization of Survival", Journal of International Affairs, 53, n.2, pp. 503524. 
Sassen, Saskia (2003), Contrageografias de la globalización. Género y ciudadanía en los circuitos transfronterizos. Madrid: Traficantes de sueños.

Scott, Joan (2009), "Sexularism" in Robert Schumann Centre for Advanced Studies Distinguished Lecture, European University Institute, Florence.

Scott, Joan (1990), "El género; una categoría útil para el análisis histórico" in Amelang, J \& M. Nash (eds.), Historia de género. Las mujeres en la Europa moderna y contemporánea. Valencia, Alfons el Magnanim, pp. 23-55.

Spivak, Gayatri Chakravorty (1988), “Can the Subaltern Speak?” In Cary Nelson and Lawrence Grossberg (eds.), Marxism and the Interpretation of Culture, Urbana: University of Illinois Press, pp. 271-313.

Squatting Europe Kollective (2013), Squatting in Europe: Radical Spaces, Urban Struggles, Minor Composition, Autonomedia.

Stacey, J. (1988), 'Can There Be a Feminist Ethnography?', Women's Studies International Forum 11, n.1, pp. 21-27.

Stengers, Isabelle (2005), "The Cosmopolitical Proposal" in Bruno Latour \& Peter Weibel (Eds.) Making Things Public, Cambridge: MIT Press, pp. 994-1003.

Stout. M. Noelle (2014), After Love. Queer intimacy and erotic economies in post-soviet Cuba, Duke University Press.

Svasek, Maruska (2010), "On the Move: Emotions and Human Mobility”, Journal of Ethnic and Migration Studies, 36, n. 6, pp. 865-880.

Svasek, Maruska, Skrbis, Zlatko (2007), "Passions and Powers: Emotions and Globalisation", Identities: Global Studies in Culture and Power, 14, pp.367383.

Treacher Kabesh, Amal (2013a), "The necessity of the Other", in Postcolonial masculinities, Ashgate, pp. 43-65.

Treacher Kabesh, Amal (2013b), "Precarious Power", in Postcolonial masculinities, Ashgate, pp. 103-119.

Trejo Velasco, Margarita (2015), Transmigración centroamericana. Motivaciones, riesgos y estrategias en el trayecto hacia un sueño, GEMMA Erasmus Mundus Master's degree of Women's and Gender Studies, Granada.

Vives, Luna (2012), "Fragmented Migrant (Her)Stories: Multi-sited Ethnography and Feminist Migration Research", in Bonifacio, G. T. (ed), Feminism and Migration. Cross-Cultural Engagements, London, Springer, pp. 61-77.

Walby Sylvia (2015), Crisis, Polity Press. 
Watson, Helen (1994), "Separation and Reconciliation: Marital Conflict among the Muslim Poor in Cairo", in Fawzi El Soth, Camillia and Mabro, Judy (eds.) Muslim Women's Choices: Religious Belief and Social Reality, pp. 33-54.

Wynter, Sylvia (1994), "No Humans Involved: An Open Letter to My Colleagues", in Forum N.H.I. - Knowledge for the $21^{\text {st }}$ Century: Knowledge on Trial, 1, n.1, pp. $42-73$.

Zontini, Elisabetta (2010), Transnational families, Migration and Gender. Moroccan and Filippino Woman in Bologna and Barcelona, Bergham Books.

Zlotnik, Hania (1995), "Migration and the Family: The Female Perspective", Asian and Pacific Migration Journal, 4 n. 2-3, pp. 253-271. 


\section{Websites}

\section{Introduction}

http://www.inventati.org/cortocircuito/2014/06/05/sgomberata-loccupazione-di-via-pier-capponi-51/

https:/femeninorural.wordpress.com/2016/01/16/crecen-las-casas-de-mujeres-autogestionadas-en-grecianinguna-sola-durante-la-crisis/

http://www.huckmagazine.com/perspectives/activism-2/24-hours-sisters-uncut/

http://www.ilfattoquotidiano.it/2014/07/02/servizi-sociali-case-inadeguate-e-un-gruppo-di-donne-occupaun-hotel/1047296/

\section{Chapter One: Love}

https://www.washingtonpost.com/news/worldviews/wp/2016/06/13/here-are-the-10-countries-wherehomosexuality-may-be-punished-by-death-2/

\section{Chapter Two: Migration}

https://www.iom.int/news/over-3770-migrants-have-died-trying-cross-mediterranean-europe-2015

http://missingmigrants.iom.int/latest-global-figures

http://www.ingenere.it/articoli/sfruttamento-donne-cinesi-italia

http://www.lastampa.it/2015/09/06/esteri/cosa-prevede-il-trattato-di-dublino-e-perch-litalia-lo-vuolecambiare-ImRFPSmHhWANp4UqSXjVbO/pagina.html

http://espresso.repubblica.it/attualita/2016/05/12/news/il-caporalato-e-1-agromafia-un-economia-illegaleda-17-miliardi-di-euro-1.265135

www.istat.it/immigrati/indicatori-sintetici/profilo-per-cittadinanza

http://www.istat.it/it/files/2016/06/Bilancio-demografico-2015-

1.pdf?title $=$ Bilancio + demografico + nazionale $+-+10 \% 2 \mathrm{Fgiu} \% 2 \mathrm{~F} 2016+-+$ Testo + integrale.pdf

http://www.ilsole24ore.com/art/notizie/2014-02-11/popolazione-crescita-grazie-immigrati-

114440.shtml?uuid=ABDXFov\&nmll=2707\#navigation

http://clashcityworkers.org/documenti/analisi/2109-truffa-jobs-act.html\#2

http://27esimaora.corriere.it/articolo/boldrini-loccupazione-femminilee-unarma-antiviolenzama-il-jobsact-non-sta-aiutando-le-donne/

http://eipcp.net/transversal/0508/doucettehuber/it

https://luchaysiesta.wordpress.com/chi-siamo-2/

http://ilmanifesto.info/roma-il-centro-antiviolenza-rischia-la-chiusura/

http://espresso.repubblica.it/inchieste/2015/12/18/news/senza-casa-il-dramma-degli-sfratti-in-italia-sispecula-ma-aumenta-chi-non-ha-un-tetto-1.243938?ref=HRBZ-1 
http://ilmanifesto.info/lupi-e-squali-ecco-il-piano-casa/

\section{Chapter Three:}

http://www.theguardian.com/global-development-professionals-network/2015/may/05/abortion-inmorocco-will-the-king-approve-a-progressive-law.

https://www.senato.it/1025? sezione=118\&articolo_numero articolo=3

\section{More informations}

https://progettodegage.org

http://firenzedalbasso.org

https://lottaperlacasafirenze.noblogs.org

http://www.inventati.org/lottaxlacasa/

https://www.facebook.com/movimentodilotta.perlacasafirenze

https://twitter.com/lottaxlacasa

https://twitter.com/firenzedalbasso?ref_src=twsrc $\% 5 \mathrm{Etfw}$

https://www.facebook.com/firenzedalbasso/?fref=ts

http://www.inventati.org/cortocircuito/2013/10/26/prima-di-tutto-donne-occupazione-al-femminile-invia-crimea/

http://www.radiondadurto.org/2014/06/09/firenze-occupato-un-ex-albergo-vuoto-dal-1999/

http://www.inventati.org/cortocircuito/2014/06/10/emergenza-abitativa-sfratti-e-sgomberi-riflessioni-suunestate-gia-troppo-calda/

http://altracitta.org/2014/06/13/loccupazione-delle-donne-trasloca-ma-non-molla-no-a-strutture-prigionedateci-case-vere/

http://altracitta.org/2015/02/04/da-oggi-al-concorde-10-bambini-al-freddo-a-norma-di-legge/

http://altracitta.org/2014/11/06/occupazioni-a-novoli-molto-piu-che-case/

http://eipcp.net/transversal/0508/doucettehuber/en

http://asia.usb.it/index.php?id=20\&tx_ttnews\%5Btt_news $\% 5 \mathrm{D}=73929 \& \mathrm{cHash}=82 \mathrm{c} 4069 \mathrm{f} 77 \& \mathrm{MP}=63-$ $\underline{875}$

https://www.facebook.com/notes/cristiano-armati/legge-lupi-e-articolo-5-contro-la-guerra-ai-poveri-lamigliore-difesa-è-lattacco/10152622874023290

http://scioperosociale.it

http://video.repubblica.it/economia-e-finanza/-la-casa-negata--1960-2014-archivioaamod/222242/221459

https://femeninorural.wordpress.com/2016/01/16/crecen-las-casas-de-mujeres-autogestionadas-en-grecianinguna-sola-durante-la-crisis/ 
http://www.culanth.org/articles/138-precarity-s-forms

http://nena-news.it/cinema-marocco-per-il-governo-much-loved-attacca-limmagine-del-regno/

http://virtualmigrants.com/we rhere/index.htm

http://www.stranieriinitalia.it/attualita/attualita/attualita-sp-754/se-ti-picchia-non-ti-ama-e-non-e-islam-lacomunita-musulmana-contro-la-violenza-sulle-donne.html

http://nomorepotlucks.org/site/no-one-is-sovereign-in-love-a-conversation-between-lauren-berlant-andmichael-hardt/

http://www.ilsole24ore.com/art/notizie/2014-02-11/popolazione-crescita-grazie-immigrati-

114440.shtml?uuid=ABDXFov\&nmll=2707\#navigation

http://eipcp.net/transversal/0508/doucettehuber/it

http://www.heterotopiastudies.com/harvey-lefebvre-foucault/

https://noborders20miglia.noblogs.org

$\underline{\text { www.tinyletter.com/nomadas }}$

(last access on July $30^{\text {th }}, 2016$ ) 


\section{Appendix One}

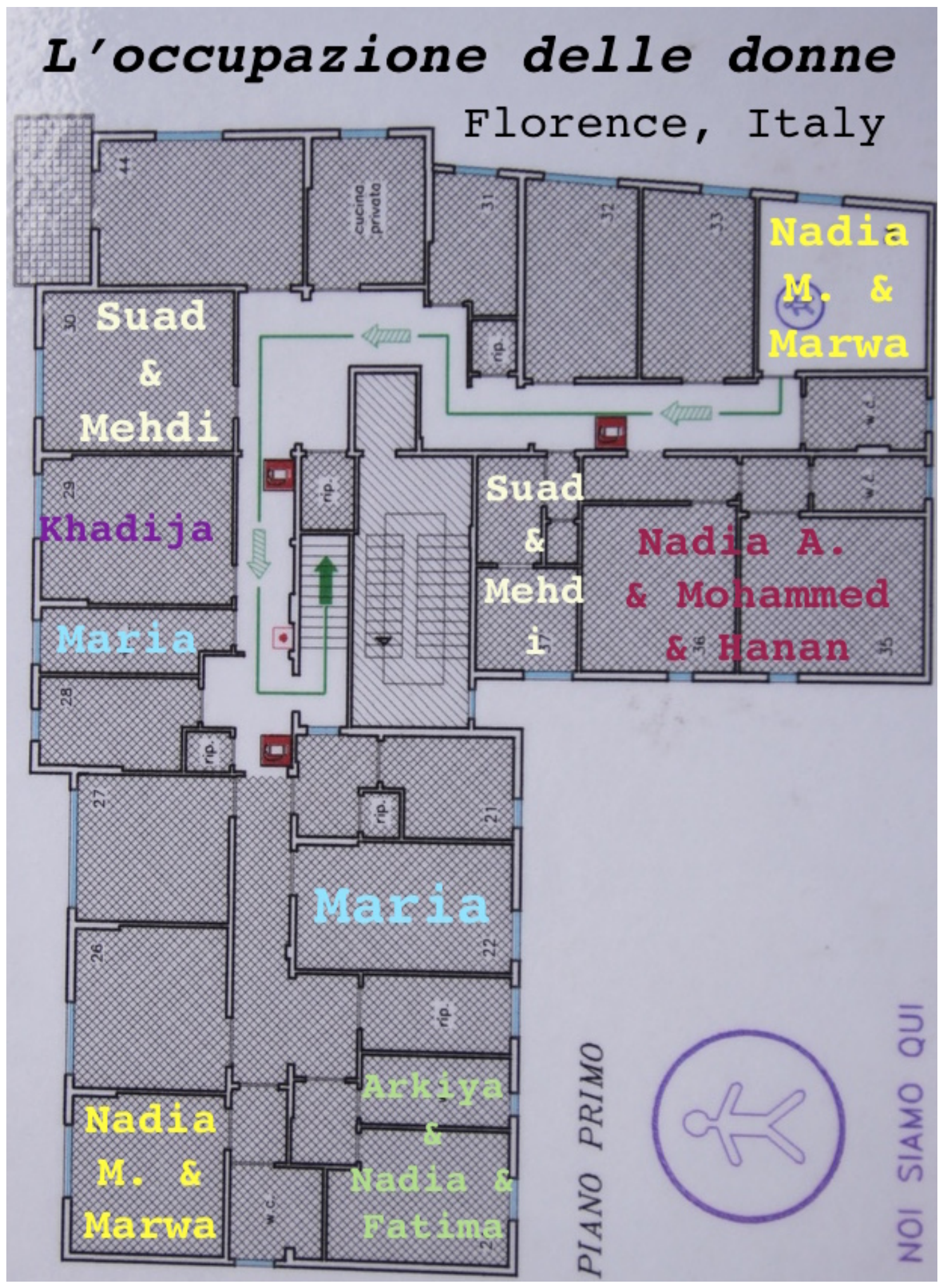




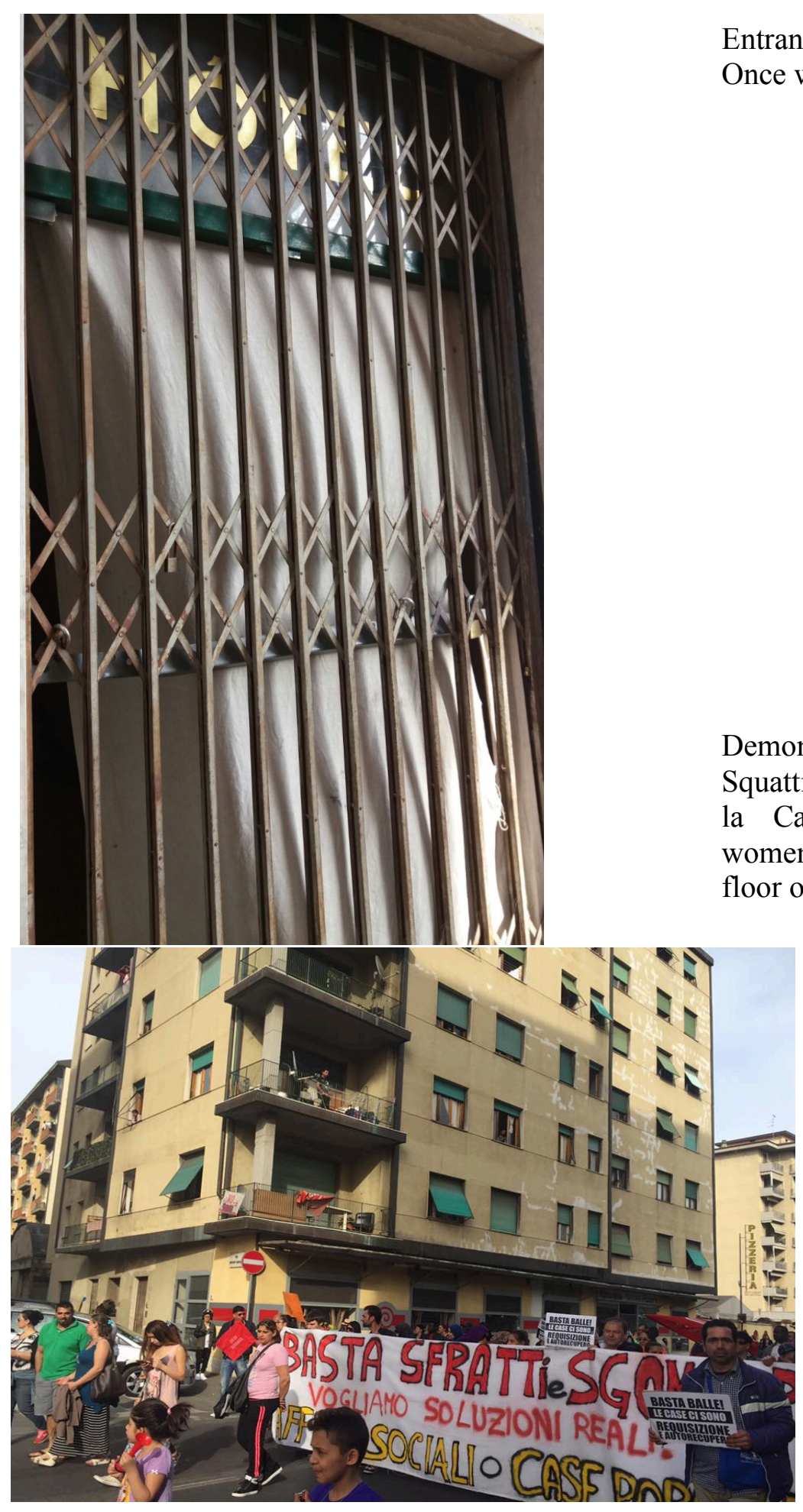




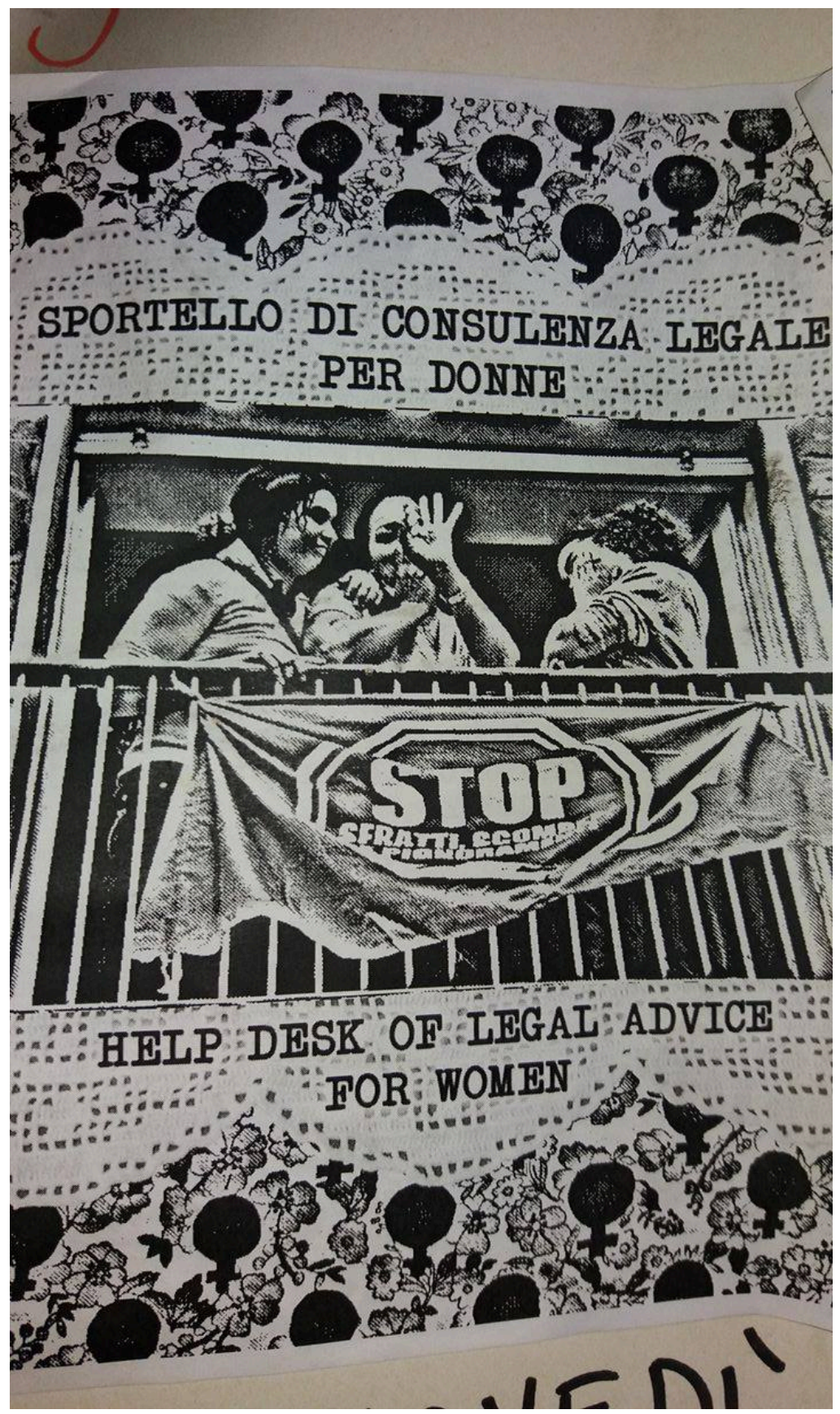

Flier of the free "help desk of legal advice for women" established at the beginning in the squat. At the time of this thesis it was not working anymore. 


\title{
Appendix Two
}

\section{WhatsApp Profile Pictures}

Some of the women's WhatsApp profile pictures are Arabic comic strips ridiculing men. Others, not presented here, are representative of their will to exhibit their religiosity and original cultural background, presenting the name of Allah or part of Koranic Suras. The latter has to do with what Ong (1987) refers to as the modern culture of icons. (For more analysis see Chapter Three, page 87).

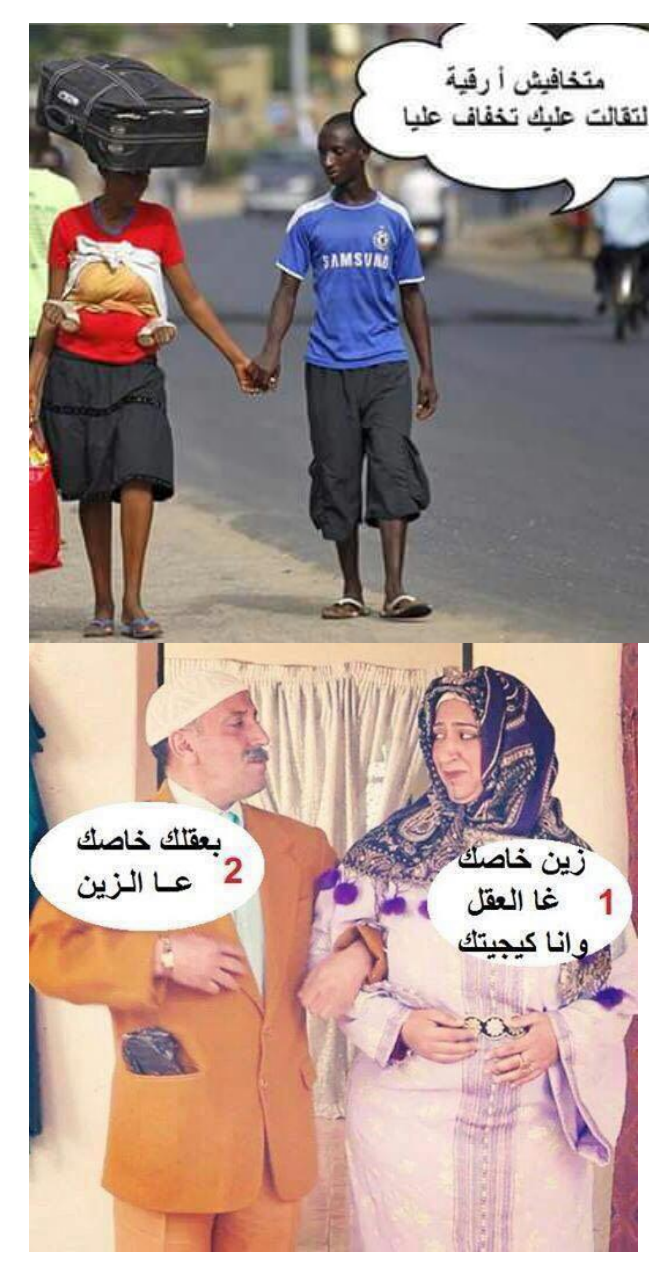

“Don't worry Raqia, I will help you carry all your burdens"

\author{
Woman: "Hey, you handsome, \\ you just lack the brain" \\ Man: "And you, wise \\ woman ... you just lack in \\ beauty!"
}

One participant, asked for the significance of these images, replied that they conveyed the idea of modern men's behaviours compared to their past ethic of altruism. This opinion inserts in a general process of sentimentalizing the past underway also in Western societies. 


\section{Appendix Three}

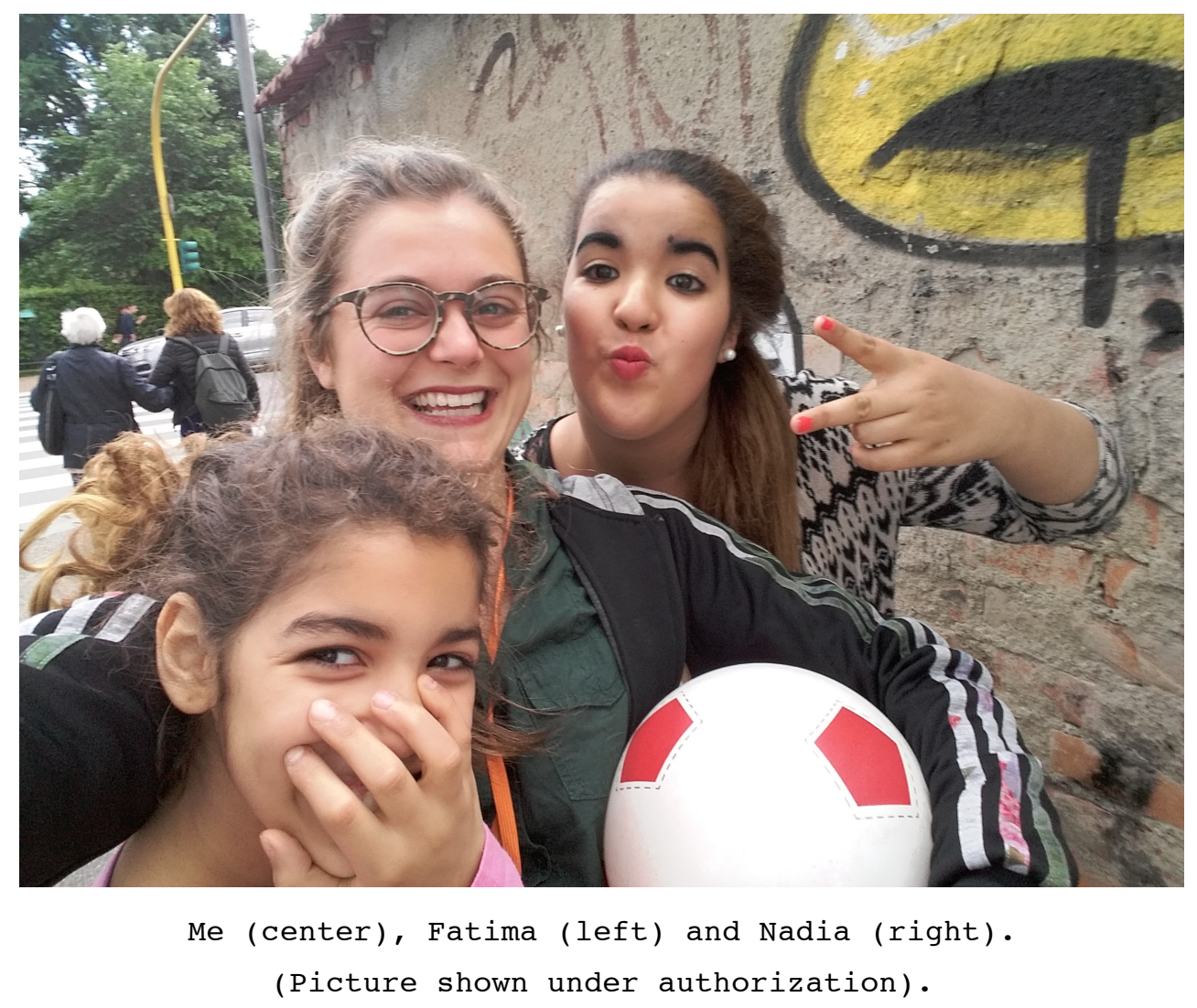

\section{Young Italian Berbers' ideas of love}

Nadia and Fatima, respectively 14 and 10 years old, consider themselves to be of mixed Italian and Moroccan, especially Berber, heritage. Although they are Muslim, they distance themselves from some Muslim practices. The same holds for Moroccan people, in general, whom they refer to using the non-inclusive pronoun "they/them." They really look forward to going to Morocco, especially to Agadir's beach, "but just for holidays...living there never!" "Not if they would pay me thousands euros!".

I have asked them about love: what it is, what they know, what they hope for, how they experience it. This interview provides testimony from an experiment that is underway: that of their becoming women. 
Me: Do you have a boyfriend?

Nadia: No...I had one in the past

Me: After that you never had anyone else?

Nadia: I don't want one anymore.

Me: Why?

Nadia: Because I don't like it.

Me: But what would you like in a boy?

Nadia: I would care about his attitude. He should care about you, treat you well.

Me: Do boys always ask girls to go out, to become boyfriend and girlfriend?

Are they the first to write on WhatsApp, the ones to decide things?

Nadia: No! Not nowadays... they decide together.

Fatima: Well, actually sometimes girls wait for the boy to do everything...

Me: Why wouldn't you like to live in Morocco?

Nadia: Because there they treat you bad [as a woman].

Fatima: There, when you work in a house, as caregiver...they treat you badly. They can even beat you... they shout at you...

Nadia: There isn 't any work contract!

Me: What do you think about it, since you have seen a bit of the world and can compare?

Nadia: They [Moroccan women] are not free; free to do things by themselves... in Italy yes...we are a bit free, without men. If you lose your things than you stay without...But women suffer more. Men go out alone, they go to the disco...they leave women alone at home...they go looking for other women. Few kind men exist, men that have a good soul, that think about their children...

Me: Why do you think women still love those men if they know all this?

Fatima: Because sometimes we think that a man is nice, that he is good...but when we marry and we get pregnant they just want the children, they don't want us anymore. Sometimes men even fall in love for money.

Nadia: I think that sometimes they seem good, they seem to us to be angels...but if you live with them and stay with them and start to know them quite well, then you realize that they are not good. In the beginning, they all treat you good, but then..."

Me: Would you like to marry?

Nadia and Fatima: No...

Fatima: I would like to have children.

Nadia: I want to live on my own. I want to work and study, to travel a lot. To live alone. I don't want that a man command me. I don't like that...I want to be free, to live my life freely. 
Fatima: I would love to have a boyfriend and children. But not to marry.

Me: Why?

Fatima: Because a man can then control me and order me [around]. A boyfriend no...I can always leave him. But if I marry him and then it turns out that he treats me badly, it's very difficult...I have to go to a lawyer and do many things...

Me: So you would like to have children without marrying?

Fatima: Of course ... you just need to make love in the bed!. 